Inert Anode/Cathode Program

Evaluation of Wear Rates and Mechanisms of Titanium Diboride-Graphite Composite Materials Proposed for Use as Cathodes in Hall-Heroult Cells

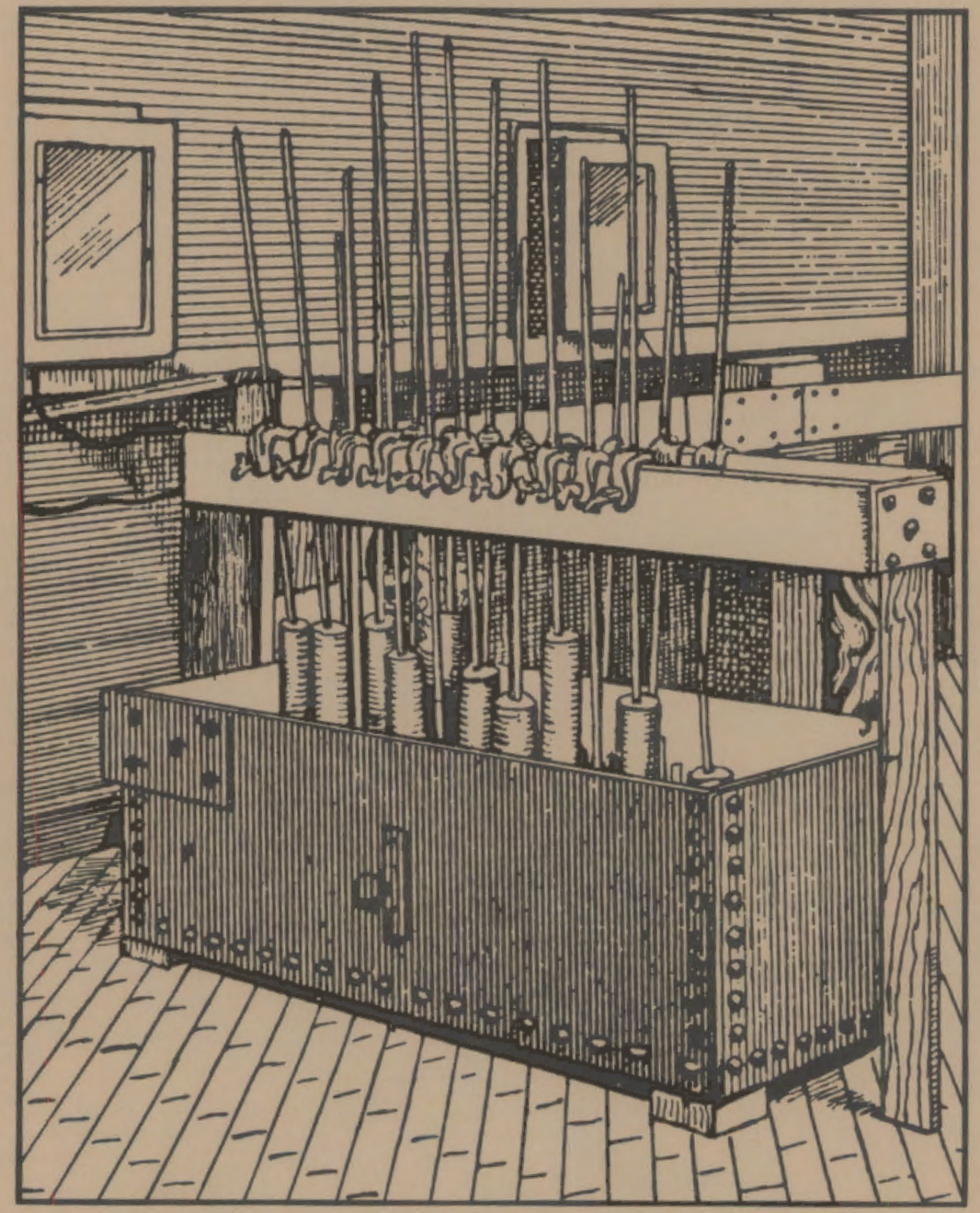

January 1987

Work Supported by the U.S. Department of Energy under Contract DE-AC06-76RLO 1830

Pacific Northwest Laboratory Operated for the U.S. Department of Energy by Battelle Memorial Institute 


\title{
DISCLAIMER
}

This report was prepared as an account of work sponsored by an agency of the United States Government. Neither the United States Government nor any agency thereof, nor any of their employees, makes any warranty, express or implied, or assumes any legal liability or responsibility for the accuracy, completeness, or usefulness of any information, apparatus, product, or process disclosed, or represents that its use would not infringe privately owned rights. Reference herein to any specific commercial product, process, or service by trade name, trademark. manufacturer, or otherwise, does not necessarily constitute or imply its endorsement, recommendation, or favoring by the United States Government or any agency thereof. The views and opinions of authors expressed herein do not necessarily state or reflect those of the United States Government or any agency thereof.

\author{
PACIFIC NORTHWEST LABORATORY \\ operated by \\ BATTELLE \\ for the \\ UNITED STATES DEPARTMENT OF ENERGY \\ under Contract DE-AC06-76RLO 1830
}

\section{On the cover:}

\author{
Aluminum reduction pots at the Pittsburgh Reduction \\ Company's (Alcoa's) plant in 1889. Adapted from a \\ photograph, courtesy of Alcoa.
}




\title{
EVALUATION OF WEAR RATES AND MECHANISMS OF TITANIUM DIBORIUE-GRAPHITE COMPOSITE MATERIALS PROPOSED FOR USE AS CATHODES IN HALL-HEROULT CELLS
}

\author{
K. H. Pool \\ J. L. Brimhall \\ P. J. Raney \\ P. E. Hart
}

January 1987

Prepared for the U.S. Department of Energy under Contract DE-AC06-76RLO 1830

Pacific Northwest Laboratory

Richland, Washington 99352 

SUMMARY

Titanium diboride $\left(\mathrm{TiB}_{2}\right)$-containing materials have been under investigation for several years as candidates for stable cathodes in Hall-Heroult aluminum reduction cells. Carbon has recently been added as a filler to $\mathrm{TiB}_{2}$ to reduce fabrication costs, permit the use of reduced amounts of lower cost $\mathrm{TiB}_{2}$, and improve the thermal shock resistance of the cathode block.

The purpose of this study was to measure the initial wear rates of $\mathrm{TiB}_{2}$ carbon-containing cathode materials $\left(\mathrm{TiB}_{2}-\mathrm{G}\right)$ under electrolytic conditions. Parameters evaluated included bath ratio, current density, and aluminum pad thickness. Two types of $\mathrm{TiB}_{2}-\mathrm{G}$ materials were supplied by the Great Lakes Carbon Company for evaluation. The materials differed in the concentration, size, and ways the separate $\mathrm{TiB}_{2}$ and carbon phases were interconnected. These materials are undergoing long-term evaluations in full-size Hall-Heroult cells in a program sponsored by the Electric Power Research Institute (EPRI).

In order to measure initial wear rates, the tests were limited to $8 \mathrm{~h}$. The prime wear mechanism of the $\mathrm{TiB}_{2}-\mathrm{G}$ is thought to be the reaction of aluminum metal and/or metallic sodium plus bath components with the carbon phase to form $\mathrm{Al}_{4} \mathrm{C}_{3}$. The reaction product is then transported through the aluminum $\mathrm{film}$ that wets the cathode and into the bath. The wear rate of the $\mathrm{TiB}_{2}-\mathrm{G}$ cathode was estimated by measuring the build-up of $\mathrm{Al}_{4} \mathrm{C}_{3}$ in the bath. Since the solubilities of $T i$ and $B$ in $A 1$ are low, and high in cryolite, the wear rate of the $\mathrm{TiB}_{2}-\mathrm{G}$ could be limited by either the rate of reaction of $\mathrm{Al}$ (or $\mathrm{Na}+$ cryolite) with graphite or the rate of diffusion of reactants and products through the intervening layer of $\mathrm{Al}$ that wets the $\mathrm{TiB}_{2}-\mathrm{G}$ cathode.

A cell and a sampling technique were developed to monitor $\mathrm{Al}_{4} \mathrm{C}_{3}$ build-up during transference cell operation. Based on $\mathrm{Al}_{4} \mathrm{C}_{3}$ accumulation rates observed in B-h tests, extrapolated annual wear rates of $\mathrm{TiB}_{2}-\mathrm{G}$ under thin $\mathrm{Al}$ film conditions can be calculated. Linear extrapolation yields annual wear rates of 4.6 to $26 \mathrm{~cm} / \mathrm{yr}$. Parabolic extrapolation yields values of 0.18 to $0.67 \mathrm{~cm}$ wear in the first year's service. (Both extrapolations assume 50 vol\% C in TiB $2-G$ ). 
Micrographs of post-test $\mathrm{TiB}_{2}-\mathrm{G}$ specinens ssggest that during short-term tests $\mathrm{TiB}_{2}$ particles are loosened from the $\mathrm{TiB}_{2}-1 \mathrm{~s}$ matrix and are removed from the active electrolysis surface as a slurry or suspended $\mathrm{TiB}_{2}$ particles in liquid Al. Only in one test was evidence of $\mathrm{Al}_{4} \mathrm{C}_{3}$ found in the $\mathrm{TiB}_{2}$-G cathode reaction interface layer or in the frozen thin film of Al metal adhering to the cathode at the end of the test.

The equilibrium solubility of $\mathrm{Al}_{4} \mathrm{C}_{3}$ in $\mathrm{Al}$ metal is $0.36 \mathrm{mg} \mathrm{Al}_{4} \mathrm{C}_{3} / \mathrm{g} \mathrm{Al}$ (Dewing 1974). Transference cell test results indicated that about $13 \mathrm{mg}$ of $\mathrm{Al}_{4} \mathrm{C}_{3}$ is produced per gram of $\mathrm{Al}$ metal. Since only limited evidence for $\mathrm{Al}_{4} \mathrm{C}_{3}$ could be found in the $\mathrm{TiB}_{2}-\mathrm{G}$ cathode reaction inverface layer, the $\mathrm{Al}_{4} \mathrm{C}_{3}$ formed must be rapidly transported to the cryolite bath for dissolution and dispersion rather than persist as $\mathrm{Al}_{4} \mathrm{C}_{3}$ dissolved in $\mathrm{Al}$ metal.

An analytical method for determining the $\mathrm{Al}_{4} \mathrm{C}_{3}$ content in cryolite with lower detection 1 imits than previously reported has been perfected. Details of the method and performance evaluation data are given in Appendix $B$ of this report.

The thermal stability of $\mathrm{Al}_{4} \mathrm{C}_{3}$ in oxidizing and nonoxidizing atmospheres was determined in a thermal balance. In an argon atmosphere, $\mathrm{Al}_{4} \mathrm{C}_{3}$ was stable to at least $1100^{\circ} \mathrm{C}$. In dry air, $\mathrm{Al}_{4} \mathrm{C}_{3}$ was stable up to approximately $650^{\circ} \mathrm{C}$; above that, it readily reacted with $\mathrm{O}_{2}$ to form $\mathrm{A}_{1} \mathrm{O}_{3}$ and $\mathrm{CO}_{2}$. These results are presented in Appendix $C$ of this report.

NOTE:

In tests completed after this report was written, the wear behavior of $\mathrm{TiB}_{2}-\mathrm{G}$ appeared to be diminished by the presence of a protective Al film that had been on the cathode at the start of the electrolysis tests. If a layer of $A l$ is on the TiB-G at the start of a $40-h$ electrolysis test, no attack of the cathode is observed. However, if the cathode is not protected by $A$ l at the stiart of the test, $\mathrm{TiB}_{2}$ particles are found to separate from the cathode, resulting in erosion of the cathode surface. 
In the experiments covered in this report, cathode samples were not precoated with Al. The impact of no Al layer on cathode samples at the start of the tests, although not evaluated, could be significant. For example, if there were an effect of an Al layer on the cathodes tested in the experiments described in this report, it would be to reduce wear rates.

In review of this document, Great lakes Carbon staff indicated that the surfaces of the as-fabricated test specimens have higher concentrations of carbon than bulk. This higher concentration may contribute to the high initial wear rates measured in this study. 





INTRODUCTION $\ldots \ldots \ldots \ldots \ldots \ldots \ldots \ldots \ldots \ldots \ldots \ldots \ldots \ldots \ldots \ldots \ldots \ldots \ldots \ldots \ldots \ldots \ldots$

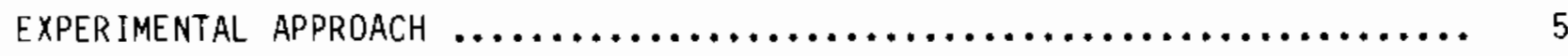

CELL DESIGN $\ldots \ldots \ldots \ldots \ldots \ldots \ldots \ldots \ldots \ldots \ldots \ldots \ldots \ldots \ldots \ldots \ldots \ldots \ldots \ldots$

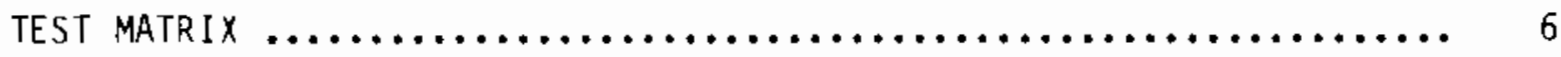

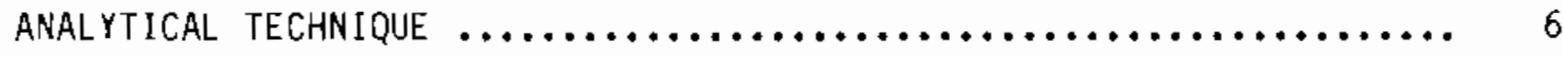

SAMPLING OURING ELECTROLYSIS $\ldots \ldots \ldots \ldots \ldots \ldots \ldots \ldots \ldots \ldots \ldots \ldots \ldots \ldots$

RESULTS AND DISCUSSION $\ldots \ldots \ldots \ldots \ldots \ldots \ldots \ldots \ldots \ldots \ldots \ldots \ldots \ldots \ldots \ldots \ldots \ldots . \ldots \ldots$

MATERIALS EXAMINED $\ldots \ldots \ldots \ldots \ldots \ldots \ldots \ldots \ldots \ldots \ldots \ldots \ldots \ldots \ldots \ldots \ldots$



TRANSFERENCE CELL RESULTS $\ldots \ldots \ldots \ldots \ldots \ldots \ldots \ldots \ldots \ldots \ldots \ldots \ldots \ldots$

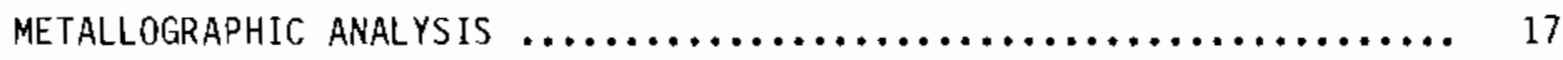

Type B Material .................................. 18

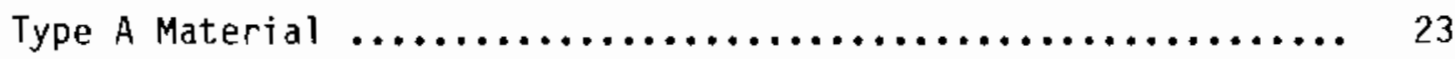

METALLOGRAPHIC AND SEM ANALYSIS OF TiB ${ }_{2}-G$ TESTED IN A

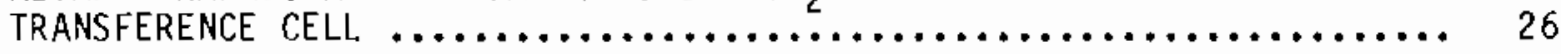

Horizontal Cathodes $\ldots \ldots \ldots \ldots \ldots \ldots \ldots \ldots \ldots \ldots \ldots \ldots \ldots \ldots \ldots$

Vertical Cathodes $\ldots \ldots \ldots \ldots \ldots \ldots \ldots \ldots \ldots \ldots \ldots \ldots \ldots \ldots \ldots \ldots . \ldots \ldots$

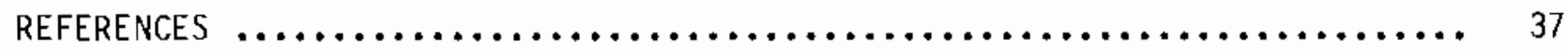

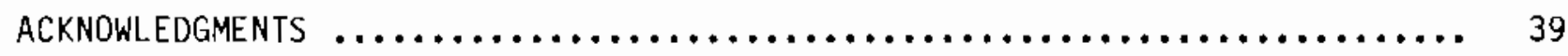

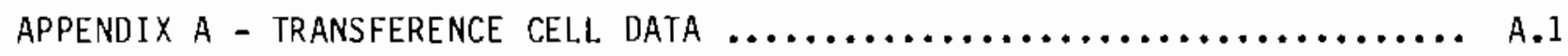

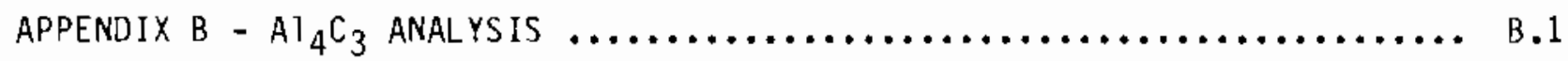

APPENDIX $C$ - THERMAL STABILITY OF ALUMINUM CARBIOE $\ldots \ldots \ldots \ldots \ldots \ldots \ldots \ldots \ldots$

APPENDIX D - ANALYSIS OF A TiB $2^{-G}$ CATHODE USING XPS AND AES $\ldots \ldots \ldots \ldots \ldots . . . .$. 

FIGURES

1 Laboratory-Scale Transference Cell ......................... 5

2 Microstructure of $\mathrm{TiB}_{2}$-G in the As-Received Condition $\ldots \ldots \ldots \ldots \ldots . .10$

3 Example of $\mathrm{TiB}_{2}-\mathrm{G}$ Cathode Tested in the Vertical Configuration.... .11

4 Aluminum Carbide Content of Bath as a Function of Electrolysis

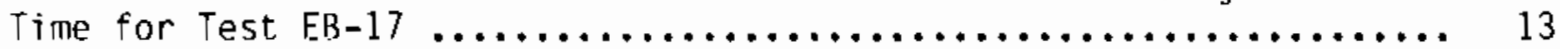

5 Aluminum Carbide Content of Bath as a Function of Electrolysis

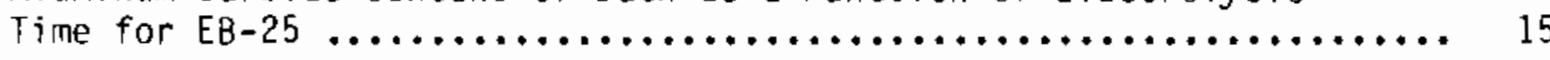

6 Aluminum Carbide Content of Bath as a Function of Electrolysis

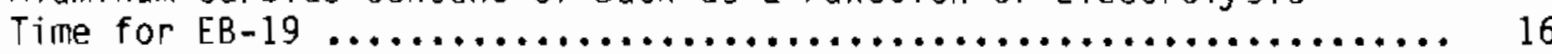

7 Aluminum Carbide Content of Bath as a Function of Electrolysis

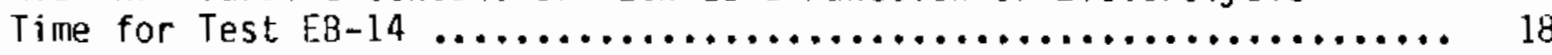

8 Optical Micrograph of Type B TiB 2 -G After Soak Test in Cryolite .... 19

9 Elemental Maps of Type B $\mathrm{TiB}_{2}$-G After Soak Testing in Cryolite $\ldots . . .20$

10 Backscattered Electron Micrograph Showing Compositional Variation in Reaction Zone of Type A Material ................. 23

11 Enlargement of Scale Region Shown in Figure $10 \ldots \ldots \ldots \ldots \ldots \ldots . \ldots 24$

12 Ti Elemental Map Showing High Ti Concentration with Light Band

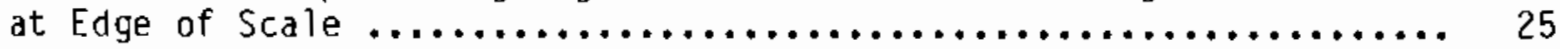

13 B Elemental Map $\ldots \ldots \ldots \ldots \ldots \ldots \ldots \ldots \ldots \ldots \ldots \ldots \ldots \ldots \ldots \ldots, 25$

14 Al Deposited on Type $A^{T i B}{ }^{-G}$ Cathode in Test EB-16 $\ldots \ldots \ldots \ldots \ldots . \ldots 27$

15 Cross Section of $\mathrm{A} 1$ on $\mathrm{TiB}_{2}-\mathrm{G}$ Cathode in Test $\mathrm{EB}-19 \ldots \ldots \ldots \ldots \ldots \ldots 28$

16 Magnification of Region A in Figure $15 \ldots \ldots \ldots \ldots \ldots \ldots \ldots \ldots . . . \ldots . \ldots . \ldots$

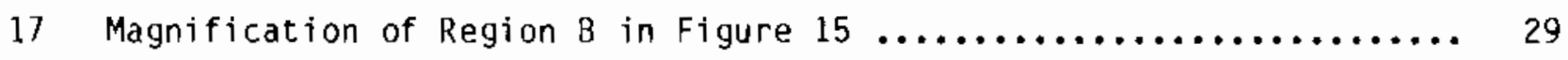

18 Cross Section of $\mathrm{Al}$ on $\mathrm{TiB}_{2}-\mathrm{G}$ Cathode in Test EB-18 $\ldots \ldots \ldots \ldots \ldots \ldots . .30$

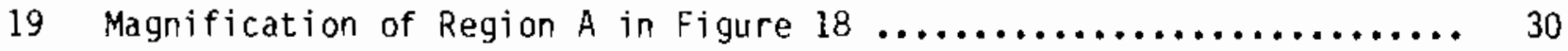

20 Type 8 Cathode Tested in the Vertical Position in Test EB-26 ....... 32

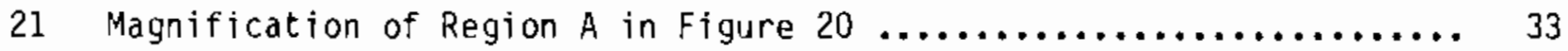


22 Magnification of Region $B$ in Figure $20 \ldots \ldots \ldots \ldots \ldots \ldots \ldots \ldots \ldots \ldots$

23 Cross Section of $A 7$ Deposited on $\mathrm{TiB}_{2}-\mathrm{G}$ in Test $\mathrm{EB}-20 \ldots \ldots \ldots \ldots$

24 Higher Magnification of Reaction Area Shown in Figure $23 \ldots \ldots . . . . .35$ 


\section{INTRODUCTION}

The Inert Anode/Cathode Program is being conducted by Pacific Northwest Laboratory $(P N L)(a)$ for the U.S. Department of Energy (DOE), Office of Indus trial Programs (OIP). The purpose of the proyram is to develop long-lasting, energy-efficient anodes, cathodes, and ancillary sensor equipment for Hail-Heroult cells used by the aluminum industry. The program is divided into four tasks with the following objectives:

- Inert Anode Development - to improve the energy efficiency of HallHeroult cells by development of inert anodes.

- Cathode Material Evaluation - to confirm the chemical behavior of carbon-containing $\mathrm{TiB}_{2}$ cathode materials $\left(\mathrm{TiB}_{2}-\mathrm{G}\right)$ in the presence of molten cryolite and aluminum and to upgrade the analytical procedures for determining $\mathrm{Al}_{4} \mathrm{C}_{3}$ in cryolite.

- Stable Cathode Studies - to develop methods for retrofitting Hal1Heroult cells with $\mathrm{TiB}_{2}$-based cathode materials.

- Sensor Development - to devise sensors to control the chemistry of Hall-Heroult cells operated with stable anodes and cathodes.

The basic objective of the work discussed in this report was to determine the wear rate and wear mechanism of $\mathrm{TiB}_{2}{ }^{-G}$ as a replacement for carbon as the cathode material in a Hall-Heroult aluminum reduction cell. $\mathrm{TiB}_{2}-\mathrm{G}$ is relatively inert to chemical attack by Hall-Heroult electrolyte (cryolite) and is "wetted" by molten aluminum, whereas carbon and graphite are not. Compared with carbon-based cathodes, swelling and erosion can be greatly reduced by using $\mathrm{TiB}_{2}-\mathrm{G}$.

A sufficiently low $\mathrm{TiB}_{2}{ }^{-G}$ wear rate and wetting of $\mathrm{TiB}_{2}{ }^{-G}$ by $\mathrm{Al}$ may lead to the use of dimensionally stable drained cathodes in Hall-Heroult cells.

(a) Operated for DOE by Battelle Memorial Institute under Contract DE-AC06-76RLO 1830. 
Consequently, the anode/cathode distance of an operating cell could be reduced and more consistently controlled at an optimum spacing, which will lead to lower electrolyte "iR" loss and increased cell efficiency.

The addition of graphite to $\mathrm{TiB}_{2}$ permits the use of smaller amounts of lower cost $\mathrm{TiB}_{2}$ in the cathode, improves the thermal shock resistance of the cathode, and results in lower cost fabrication routes and the ability to fabricate more complex cathode shapes.

Two mechanisms have been proposed as the cause of wear of $\mathrm{TiB}_{2}-\mathrm{G}$ cathode materials: 1) cathodically produced $A l$ may react, with the carbon in $\mathrm{TiB}_{2}-\mathrm{G}$ to produce $\mathrm{Al}_{4} \mathrm{C}_{3}$ or 2) cathodically produced $\mathrm{Na}$ together with bath components may react with the carbon to produce $\mathrm{Al}_{4} \mathrm{C}_{3}$. Prior to significant $\mathrm{Al}$ production in the cell, reaction 2 could predominate. Following the formation of an Al layer in the cathode, reaction 1 could predominate. The reaction products would be transported either by diffusion or convection through the intervening $A l$ and/or cryolite layer. Upon reaching bulk cryolite bath, the $\mathrm{Al}_{4} \mathrm{C}_{3}$ readily dissolves and is dispersed. Once exposed to oxygen in the bath, $\mathrm{Al}_{4} \mathrm{C}_{3}$ is rapidly oxidized to $\mathrm{Al}_{2} \mathrm{O}_{3}$. Therefore, in the current tests, oxygen (and traces of moisture) had to be rigorously excluded from the test environment to prevent loss of the $\mathrm{Al}_{4} \mathrm{C}_{3}$ reaction product.

In a drained cathode configuration, the thickness of the Al film coating on the $\mathrm{TiB}_{2}-\mathrm{G}$ will depend on, among other things, the slope of the cathode surface with respect to the horizontal. The steeper the slope, the thinner the Al coating should be. The thinner the Al film, the faster the rate of transport of $\mathrm{Al}_{4} \mathrm{C}_{3}$ through the $\mathrm{Al}$ film to the electrolyte. Since $\mathrm{Al}_{4} \mathrm{C}_{3}$ solubility in the electrolyte bath is greater than in molten $A 1$ and the rate-determining step for $\mathrm{TiB}_{2}-\mathrm{G}$ wear is hypothesized to be the transport step in the mechanism noted above, the overall observed rate of $\mathrm{TiB}_{2}-\mathrm{G}$ degradation should depend on the $\mathrm{Al}$ thickness, which is in turn controlled by the cathode surface slope.

In a comercial cell with carbon cathodes, very small concentrations of $\mathrm{Al}_{4} \mathrm{C}_{3}$ can be found in electrolyte bath samples. Bath and metal samples from a comnercial cell were analyzed for $\mathrm{Al}_{4} \mathrm{C}_{3}$ content by Reynolds Aluminum for DOE with the following results: $0.0040 \pm 0.0002$ wt $\% \mathrm{Al}_{4} C_{3}$ in the bath and 
$<0.003$ wt\% in the metal. Because $\mathrm{Al}_{4} \mathrm{C}_{3}$ is easily destroyed by any oxidizing agent $\left(\mathrm{O}_{2}\right.$ in the air, even $\mathrm{CO}_{2}$ and $\left.\mathrm{H}_{2} \mathrm{O}\right)$, the low concentrations of $\mathrm{Al}_{4} \mathrm{C}_{3}$ found in the bath samples are not surprising.

If a laboratory-scale cell were set up that rigorously excluded adventitious oxidants and if the anode reaction product were not oxidizing to any bath components, then the rate of wear of a $\mathrm{TiB}_{2}-\mathrm{G}$ cathode could be inferred from the rate of $\mathrm{Al}_{4} \mathrm{C}_{3}$ accumulation in the bath. Such a cell was designed and used in this work. This cell is referred to as a "transference cell" throughout this report. Samples from the bath were withdrawn from the cell periodically during electrolysis and analyzed for $\mathrm{Al}_{4} \mathrm{C}_{3}$ content using the analytical procedure discussed in this report. The slope of the curve generated by plotting $\mathrm{Al}_{4} \mathrm{C}_{3}$ content of the bath versus time of electrolysis is a measure of the $\mathrm{TiB}_{2}-\mathrm{G}$ degradation rate. 



\section{EXPERIMENTAL APPROACH}

The cell design, test matrix, analytical technique, and sampling technique are discussed in this section.

\section{CELL DESIGN}

The design of the transference cell shown in Figure 1 evolved from a series of preliminary designs. The cryolitic bath was contained in a closed

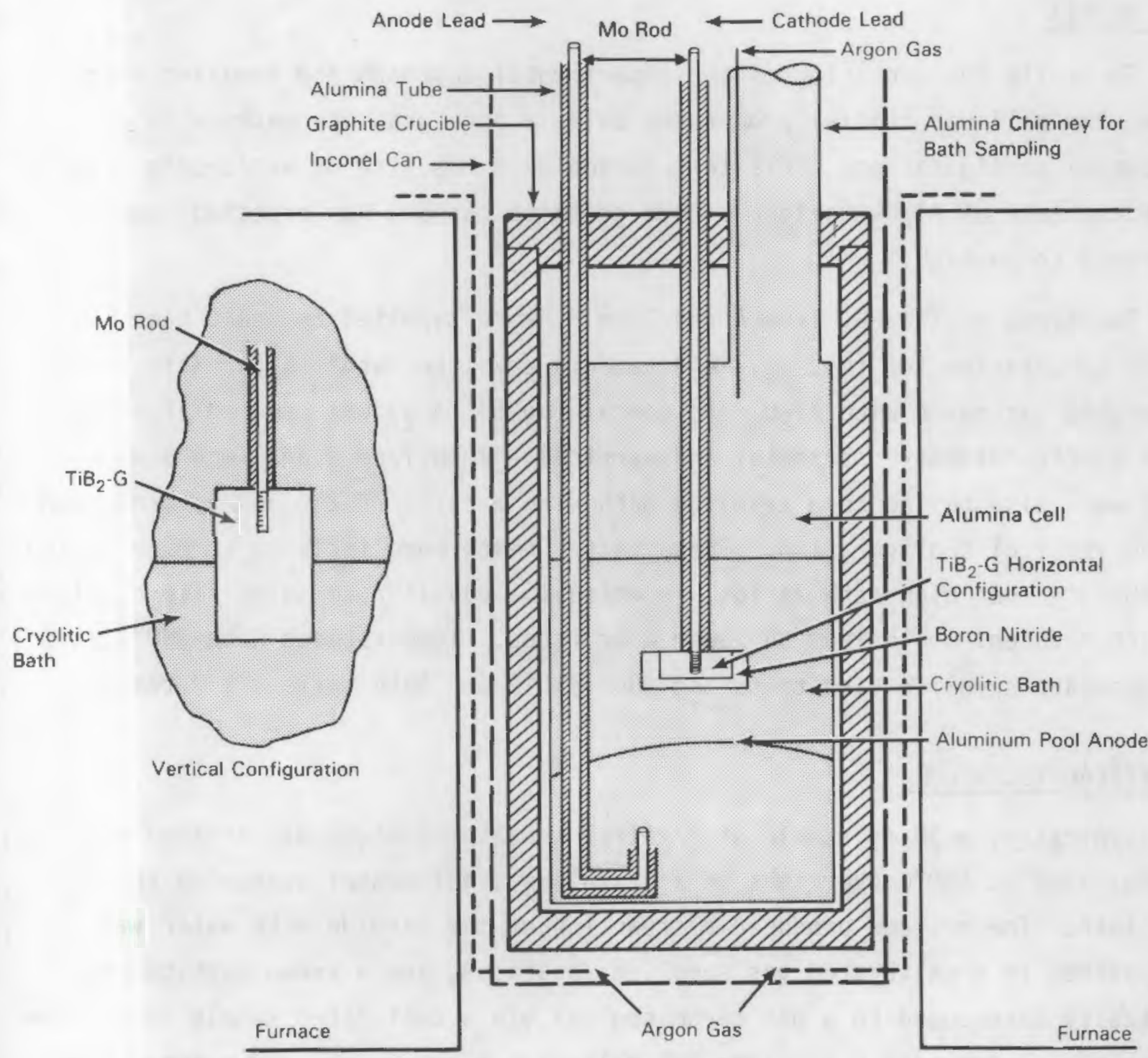

FIGURE 1. Laboratory-Scale Transference Cell 
aluminum oxide cell. Although a graphite crucible surrounds the cell, no graphite components were in contact with the bath. The final cell design excluded oxygen penetration and allowed electrolysis times up to $10 \mathrm{~h}$. Initially, there was some concern that $T i B_{2}-G$ wear rates would be so low that extended electrolysis times would be needed to observe significant $\mathrm{Al}_{4} \mathrm{C}_{3}$ buildup in the bath. The results presented in this report show that at least initial rates of $\mathrm{TiB}_{2}-\mathrm{G}$ wear (and $\mathrm{Al}_{4} \mathrm{C}_{3}$ buildup) are well within detection capabilities.

\section{TEST MATRIX}

To verify the operation of the experimental approach and sampling technique, the cell was initially operated using a pure graphite cathode in a horizontal configuration. This test served as a baseline or worst-case example since the rate of $\mathrm{Al}_{4} \mathrm{C}_{3}$ buildup with a graphite cathode was expected (and observed) to be high.

Two types of $\mathrm{TiB}_{2}-\mathrm{G}$, Type $A$ and Type $B$, were supplied by Great Lakes Carbon Corporation for testing. A "standard cryolite bath" (bath ratio $=1.07$ by weight, saturated with $\mathrm{Al}_{2} \mathrm{O}_{3}$ and containing $5 \% \quad \mathrm{CaF}_{2}$ ) was used in limiting slope configurations-morizontal and vertical. Both Type $A$ and Type B materials were also tested in a cryolite bath with a ratio of 2.0 and were mounted in the vertical configuration. These latter tests were included to examine the possibility that high bath ratios, in which the equilibrium solubility of $\mathrm{Al}_{4} \mathrm{C}_{3}$ is much reduced, would lead to lower wear rates. Temperatures were $980^{\circ} \pm 15^{\circ} \mathrm{C}$ for standard cryolite bath tests and $990^{\circ} \pm 10^{\circ} \mathrm{C}$ for bath ratio $=2.0$ tests.

\section{ANALYTICAL TECHNIQUE}

Typically, a 50-mg sample of cryolite containing $\mathrm{Al}_{4} \mathrm{C}_{3}$ was treated with aqueous $\mathrm{NaOH}$ at $100^{\circ} \mathrm{C}$ overnight in a stainiess steel vessel evacuated to $<0.1$ torr. The methane produced by reaction of the carbide with water was manipulated in a calibrated gas sampling apparatus, and a known portion was eventually introduced to a gas chromatograph via a calibrated sample loop. The gas chromatograph used a 2-m-long 5-A molecular sieve column and a sensitive helium ionization detector. A standard gas mixture containing $\mathrm{CH}_{4}$ was used to 
calibrate the system. Conservatively, the detection limit was 0.001 wt\% Al ${ }_{4} \mathrm{C}_{3}$ based on a $50-m g$ sample. Precision and accuracy were better than $\pm 10 \%$ relative at the 0.1 wt\% $\mathrm{Al}_{4} \mathrm{C}_{3}$ level. Further details can be found in Appendix $\mathrm{B}$.

\section{SAMPLING DURING ELECTROLYSIS}

The molten bath was sampled by slowly lowering an alumina tube $(6-\mathrm{mm}$ inside diameter) down the chimney into the melt. The tube was flushed with argon until the end of it broke the cryolite surface; flushing was then stopped. The tube was inserted until the Al pool was contacted and then withdrawn from the melt. Capillary action was sufficient to ensure that a "core" sample of bath was obtained. The tube with the sample was allowed to cool under $\mathrm{Ar}$ in the upper portion of the chimney for a few minutes and was then removed from the chimney. The sample was easily removed from the alumina sampling tube by gentle tapping. Samples were stored in a desiccator until the analyses could be done.

Initial attempts to sample and analyze molten cryolite baths containing a known quantity of added $\mathrm{Al}_{4} \mathrm{C}_{3}$ or in cells operated with carbon cathodes gave very poor recoveries. It was found that rigorous exclusion of air was necessary to prevent loss of $\mathrm{Al}_{4} \mathrm{C}_{3}$. The cell design shown in Figure 1, along with an Ar cover gas cleanup system, a liquid $\mathrm{N}_{2}$ water trap, and heated $\mathrm{Cu}$ turnings, was developed to maintain the necessary low-oxygen partial pressure atmosphere.

The solubility of $\mathrm{Al}_{4} \mathrm{C}_{3}$ in cryolitic baths has been measured by several laboratories (Dewing 1969; Grjotheim, Naeuman, and Oye 1977; Odegard, Sterten, and Thonstad 1984). The data reveal a rather large dependence of $\mathrm{Al}_{4} \mathrm{C}_{3}$ solubility on bath ratio and only weak dependence on other parameters such as temperature, $\mathrm{CaF}_{2}$ content, and $\mathrm{Al}_{2} \mathrm{O}_{3}$ content. The model developed by Odegard, Sterten, and Thonstad (1984) fits the observed $\mathrm{Al}_{4} \mathrm{C}_{3}$ solubility versus bath ratio data over the entire bath ratio investigated $(0.43<$ bath ratio< 2.0$)$. This model suggests that the dissolution reaction is best described as:

$$
\mathrm{Al}_{4} \mathrm{C}_{3}(\mathrm{~s})+5 \mathrm{AlF}_{3}+9 \mathrm{NaF}+3 \mathrm{Al}_{3} \mathrm{CF}_{8}^{3-}+9 \mathrm{Na}^{+}
$$


This model and the data used to derive it indicate that $\mathrm{Al}_{4} \mathrm{C}_{3}$ has a maximum solubility at a bath ratio of 0.9. The equilibrium solubilities of $\mathrm{Al}_{4} \mathrm{C}_{3}$ in baths used in this study are about $1.1 \mathrm{wt} \%$ (bath ratio $=1.07$ ) and $0.09 \mathrm{wt} \%$ (bath ratio $=2.0$ ) as interpolated from Dewing's data (1969). 


\section{RESULTS AND DISCUSSION}

\section{MATERIALS EXAMINED}

Two types of $\mathrm{TiB}_{2}-\mathrm{G}$ were supplied by Great Lakes Carbon for evaluation; they were designated Types A and B by Great Lakes. The processes for manufacturing these materials have not been disclosed by Great Lakes. Micrographs of the materials are shown in Figure 2. The graphite phase, which is black in the micrographs, appears to be more continuous in the Type A material than in the Type B material. Porosity is also dark in the micrographs. The $\mathrm{TiB}_{2}$ phase in the Type $B$ material appears more continuous than in the Type A material. The large $\mathrm{TiB}_{2}$ particles, which appear to be agglomerates of finer particles, are finer in the Type A material than in the Type B material. The agglomerates appear more uniform in size in the Type A material than in the Type B material. No effort was made to measure the relative concentrations of the graphite, the $\mathrm{TiB}_{2}$, the porosity, or the degree of graphitization in the materials.

\section{MATERIALS TESTING}

In addition to material being evaluated in the transference cell tests, samples were soaked in cryolite for $48 \mathrm{~h}$ at $960^{\circ} \mathrm{C}$ without an applied voltage to determine the effect of cryolite alone on material performance. The results of the transference cell test will be described first, followed by the soak test results.

\section{TRANSFERENCE CELL RESULTS}

Tests were conducted to determine the effect of material type, current density, bath ratio, sample position (either vertical or horizontal) on wear rate. A photograph of a cathode and test cell is shown in Figure 3 . Results are summarized in Table 1. Rates are reported in terms of the amount of carbon lost from the surface of the sample $\left(\mathrm{mgC} / \mathrm{cm}^{2}-h\right)$ and carbon thickness lost per year $(\mathrm{cm} / \mathrm{yr})$. For the latter calculation, it was assumed that the $\mathrm{TiB}_{2}-\mathrm{G}$ was 50 vol\% $\mathrm{TiB}_{2}$ and that the carbon was lost uniformly from the surface. Lower volume fractions of carbon would increase the calculated wear rate proportionately. 


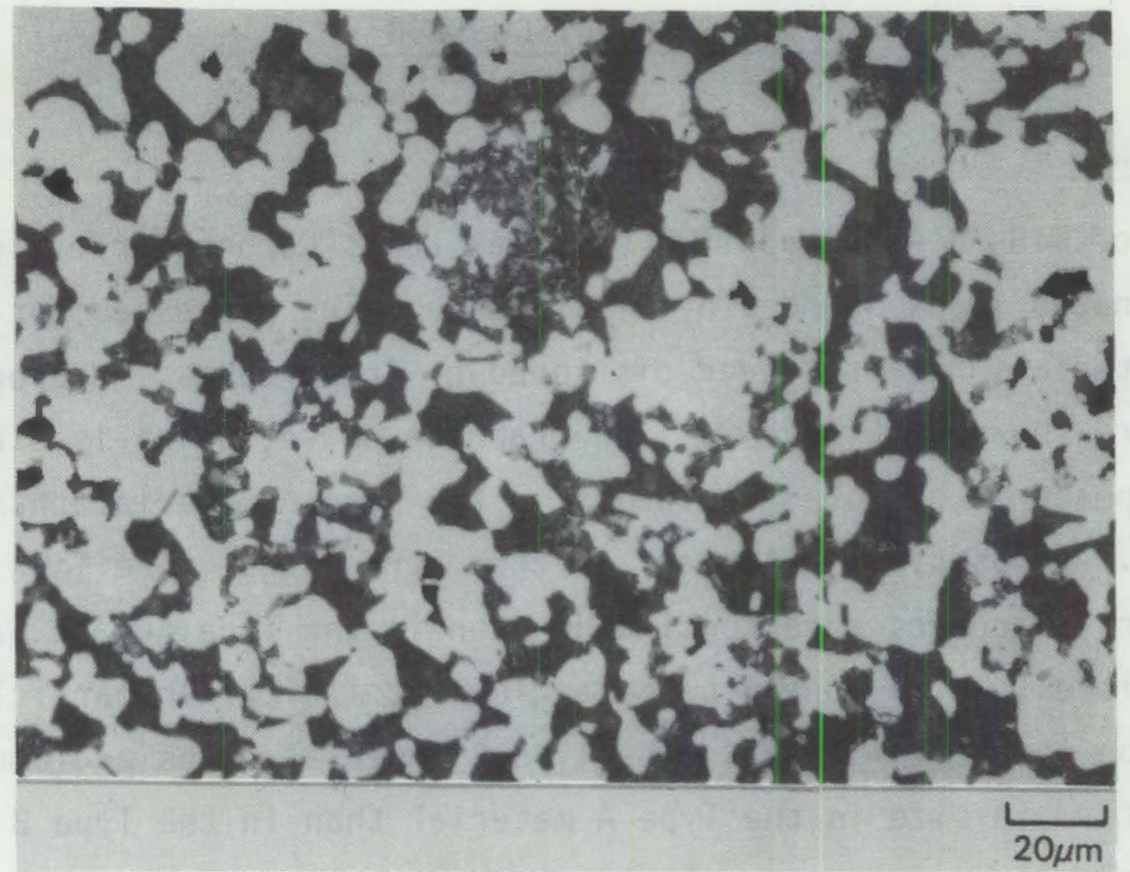

a) Type $A$

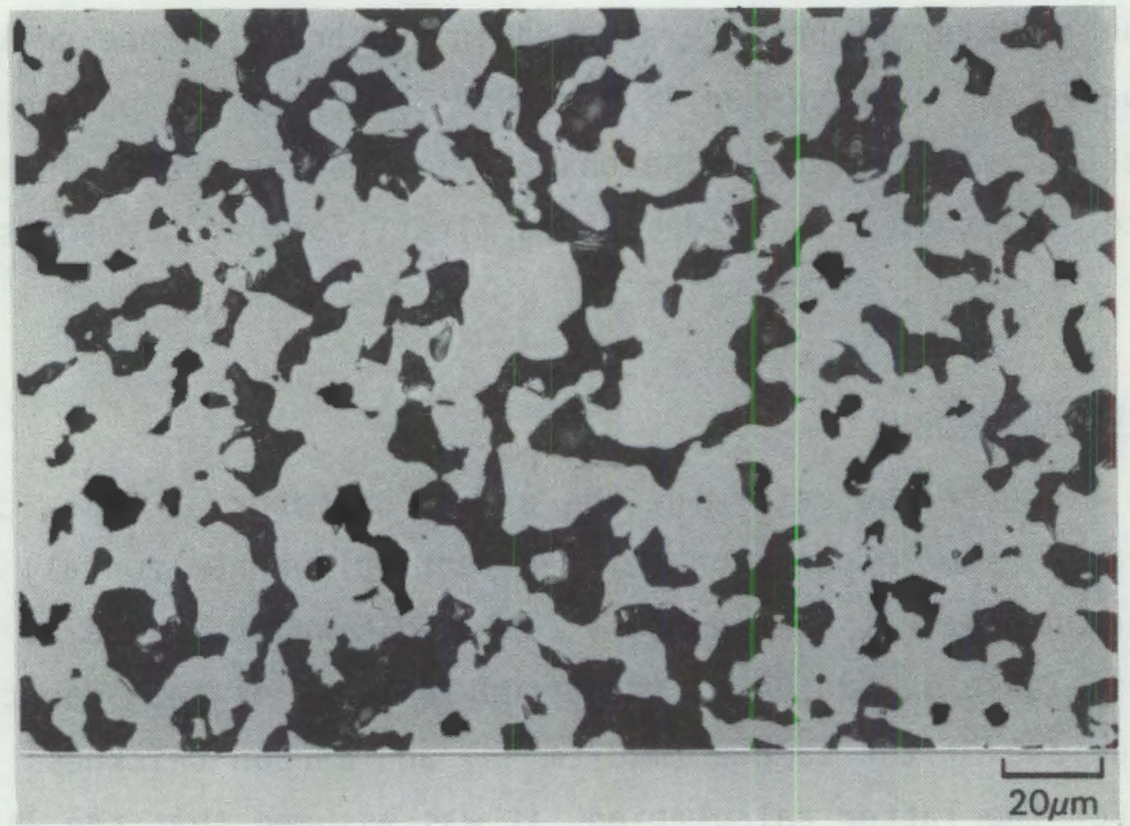

b) Type B

FIGURE 2. Microstructure of $\mathrm{TiB}_{2}-\mathrm{G}$ in the As-Received Condition 


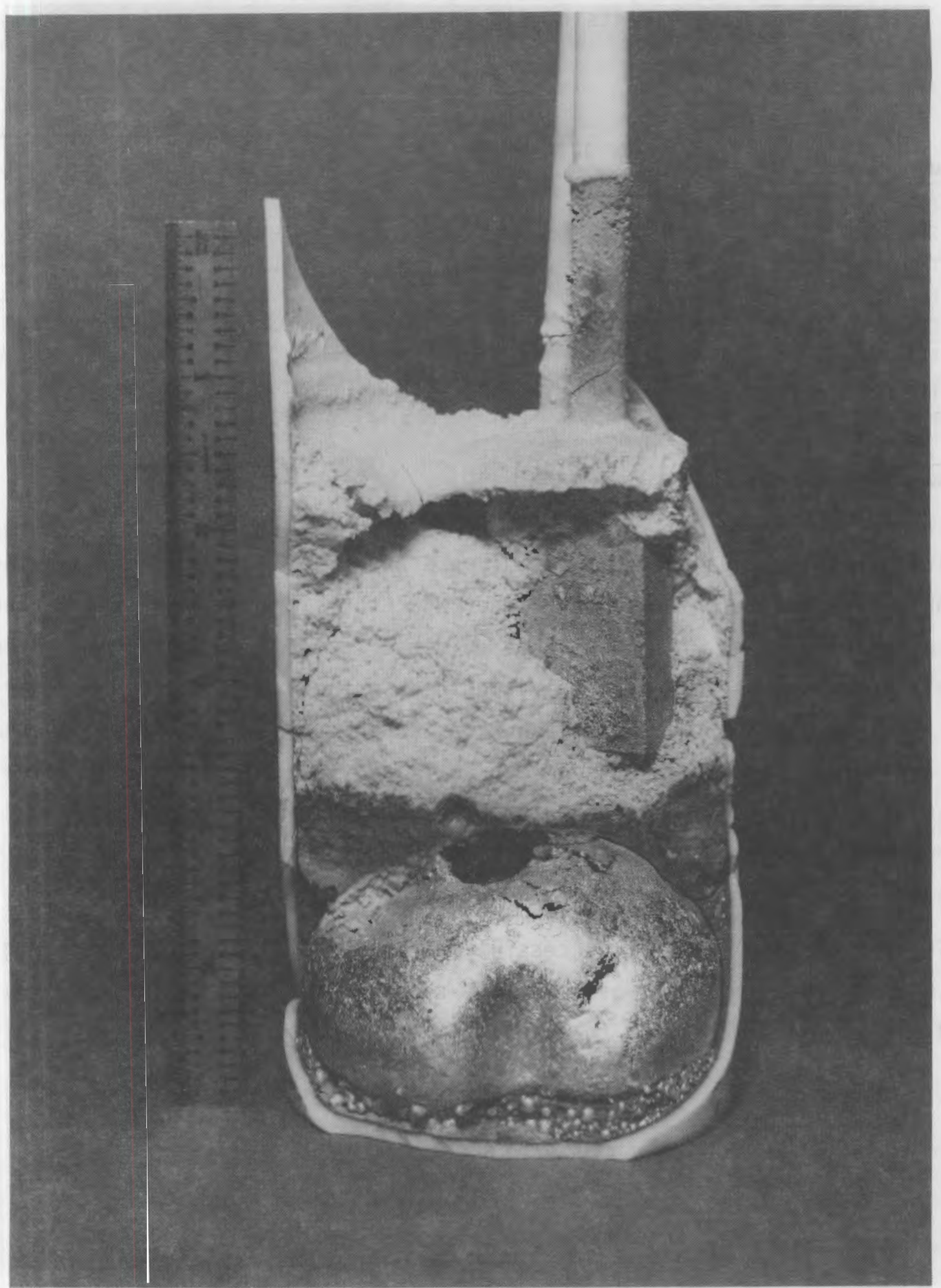

FIGURE 3. Example of $\mathrm{TiB}_{2}-\mathrm{G}$ Cathode Tested in the Vertical Configuration. The Al pool anode is at the bottom of the cell. 
TABLE 1. Summary of Results of Successful Transference

Cell Tests of $\mathrm{TiB}_{2}$ Materials

\begin{tabular}{|c|c|c|c|c|c|c|c|c|c|}
\hline \multirow[b]{3}{*}{ Test } & \multirow[b]{3}{*}{ Material } & \multirow{3}{*}{$\begin{array}{c}\text { Horizontal } \\
\text { or } \\
\text { Vertical } \\
\end{array}$} & \multirow[b]{3}{*}{$\begin{array}{l}\text { Bath } \\
\text { Ratio } \\
\end{array}$} & \multirow[b]{3}{*}{$\begin{array}{c}\text { Ares, } \\
\mathrm{cm}^{2} \\
\end{array}$} & \multirow{3}{*}{$\begin{array}{c}\text { Current } \\
\text { Density, } \\
\text { A/cm }\end{array}$} & \multicolumn{4}{|c|}{ Wear Rate } \\
\hline & & & & & & \multicolumn{2}{|c|}{$\begin{array}{c}\text { Lineer } \\
\text { Extrapolation } \\
\end{array}$} & \multicolumn{2}{|c|}{$\begin{array}{l}\text { Parabolic } \\
\text { Extrapolation }\end{array}$} \\
\hline & & & & & & $\mathrm{mgC} / \mathrm{cm}^{2}-\mathrm{h}$ & $\mathrm{cm} / \mathrm{y} \mathrm{r}^{*}$ & $\mathrm{mgC} / \mathrm{Cm}^{2}-\mathrm{h}^{1 / 2}$ & $\mathrm{~cm} / \mathrm{yr}^{* *}$ \\
\hline$\overline{E B-23}$ & $\mathrm{TiB}_{2}-\mathrm{G}-\mathrm{A}$ & $\mathrm{H}$ & 1.07 & 2.3 & 1.3 & 2.51 & 20 & 7.58 & 0.63 \\
\hline$E B-25$ & $\mathrm{TiB}_{2}-\mathrm{G}-\mathrm{A}$ & $v$ & 1.07 & 9.8 & 0.8 & $1.22-0.89$ & $9.5-7.0$ & $3.53-4.49$ & $0.29-0.37$ \\
\hline $\mathrm{EB}-30$ & $\mathrm{TiB}_{2}-\mathrm{G}-\mathrm{A}$ & $v$ & 2.00 & 10.0 & 0.8 & 0.83 & 6.5 & 2.78 & 0.23 \\
\hline$E B-17$ & $\mathrm{TIB}_{2}-\mathrm{G}-\mathrm{B}$ & $v$ & 1.07 & 13.9 & 1.04 & 0.98 & 7.6 & 3.31 & 0.28 \\
\hline$E B-24$ & $\mathrm{TIB}_{2}-\mathrm{G}-\mathrm{B}$ & $v$ & 1.07 & 9.8 & 0.8 & 0.65 & 5.1 & $2.78-3.10$ & $0.23-0.26$ \\
\hline$E B-19$ & $T / B_{2}-G-B$ & H & 1.07 & 2.3 & 1.3 & 3.13 & 24.0 & 3.63 & 0.30 \\
\hline EB-29 & $\mathrm{TIB}_{2}-\mathrm{G}-\mathrm{B}$ & H & 1.07 & 2.3 & 0.87 & $1.9-0.8$ & $15-6.3$ & 4.17 & 0.35 \\
\hline EB-27 & $T i B_{2}-G-B$ & $v$ & 2.00 & 10.0 & 1.2 & 0.54 & 4.2 & 1.92 & 0.16 \\
\hline
\end{tabular}

* Assumes $\mathrm{TiB}_{2}-\mathrm{G}$ is 50 volk $\mathrm{C}$.

It is readily apparent that both Type $A$ and Type $B \mathrm{TiB}_{2}-\mathrm{G}$ tested in the horizontal configuration exhibited higher wear rates than when tested in the vertical configuration. There is some evidence from post-test photomicrographs that electrolysis was not completely confined to the exposed horizontal surface. If this was the case, then the true current density was less than that given in Table 1 and corresponding wear rates are less than those tabulated. In Test EB-19 (Type $\mathrm{B} \mathrm{TiB}_{2}-\mathrm{G}$ in horizontal configuration), other problems occurred that increased the uncertainty of the calculated wear rate. This particular test is discussed later in this section.

The results of a typical successful test (EB-17) are summarized in Figure 4. If a linear model is assumed, the slope of the fitted straight line ( $\left.0.054 \mathrm{~g} \mathrm{Al}_{4} \mathrm{C}_{3} / \mathrm{h}\right)$ can be used to calculate wear rate by the following equation:

$$
\frac{0.054 \mathrm{~g} \mathrm{Al}_{4} \mathrm{C}_{3}}{\mathrm{~h}} \times \frac{36 \mathrm{~g} \mathrm{C}}{144 \mathrm{~g} \mathrm{Al}_{4} \mathrm{C}_{3}} \times \frac{1}{13.9 \mathrm{~cm}^{2}} \times \frac{10^{3} \mathrm{mg}}{\mathrm{g}}=0.97 \mathrm{mg} \mathrm{C} / \mathrm{cm}^{2}-\mathrm{h}
$$




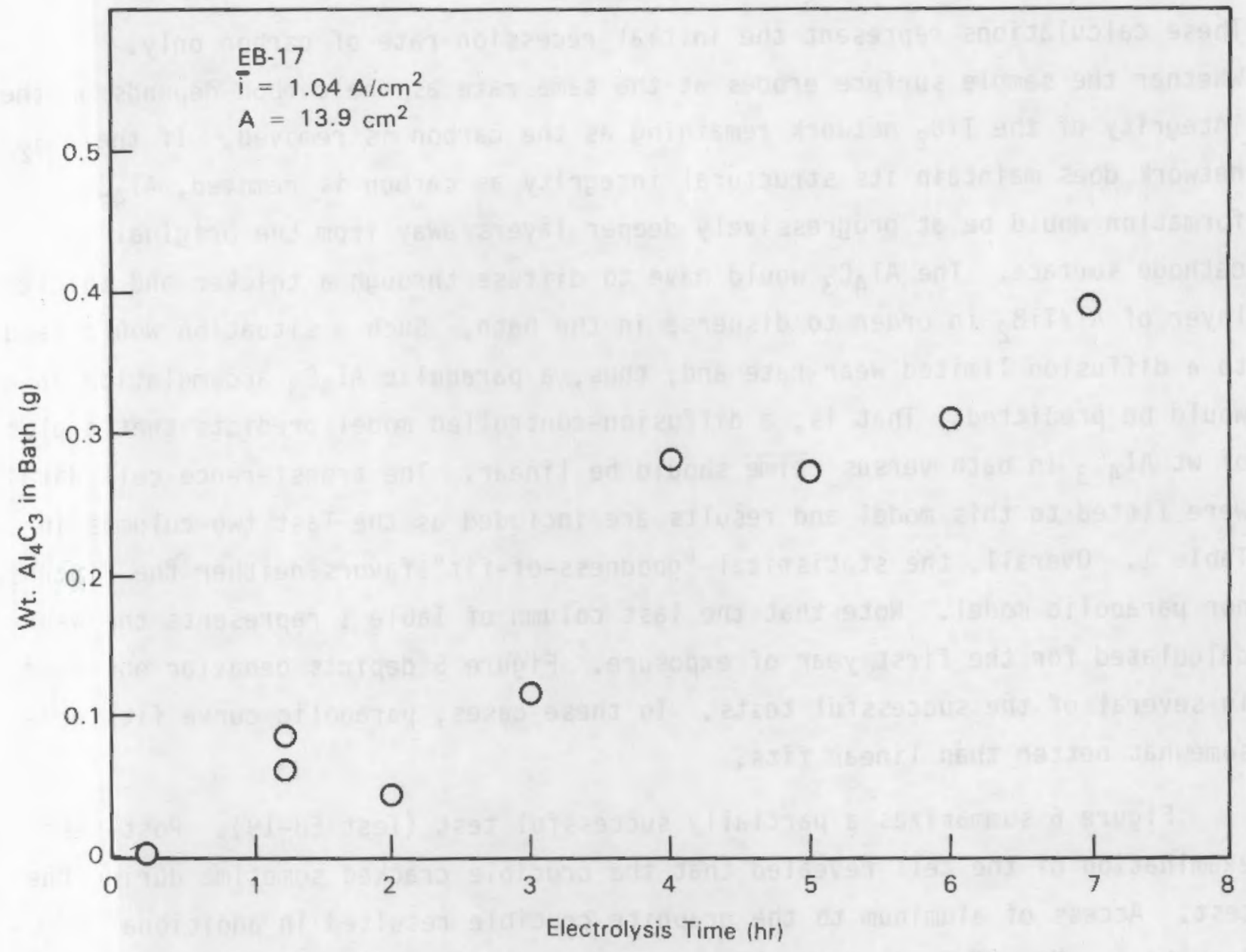

FIGURE 4. Aluminum Carbide Content of Bath as a Function of Electrolys is Time for Test EB-17

Extrapolating this wear rate to 1 year, the following annual wear rate is predicted:

$$
\frac{0.97 \mathrm{mg} \mathrm{C}}{\mathrm{cm}^{2}-\mathrm{h}} \times \frac{24 \mathrm{~h}}{\text { day }} \times \frac{365 \text { day }}{\mathrm{yr}} \times \frac{10^{-3} \mathrm{~g}}{\mathrm{mg}}=8.54 \mathrm{~g} \mathrm{C} / \mathrm{cm}^{2}-\mathrm{yr}
$$

Using the density of graphite $=2.25 \mathrm{~g} / \mathrm{cm}^{3}$, a linear wear rate of $3.80 \mathrm{~cm} \mathrm{C/yr}$ can be calculated. Finally, if the $\mathrm{TiB}_{2}-\mathrm{G}$ specimen is $50 \mathrm{v01 \%}$ carbon, the wear rate of the $\mathrm{TiB}_{2}-\mathrm{G}$ surface is $7.6 \mathrm{~cm} / \mathrm{yr}$. If the $\mathrm{TiB}_{2}-\mathrm{G}$ specimen is $25 \mathrm{vol \%}$ carbon rather that $50 \mathrm{vol} \%$, the $\mathrm{TiB}_{2}-\mathrm{G}$ wear rate is $15.2 \mathrm{cmi} / \mathrm{yr}$. For comparison purposes throughout this report, 50 vol\% carbon is used in all calculations. 
These calculations represent the initial recession rate of carbon only. Whether the sample surface erodes at the same rate as the carbon depends on the integrity of the $\mathrm{TiB}_{2}$ network remaining as the carbon is removed. If the $\mathrm{TiB}_{2}$ network does maintain its structural integrity as carbon is removed, $\mathrm{Al}_{4} \mathrm{C}_{3}$ formation would be at progressively deeper layers away from the original cathode surface. The $\mathrm{Al}_{4} \mathrm{C}_{3}$ would have to diffuse through a thicker and thicker layer of $\mathrm{Al} / \mathrm{TiB}_{2}$ in order to disperse in the bath. Such a situation would lead to a diffusion limited wear rate and, thus, a parabolic $\mathrm{Al}_{4} \mathrm{C}_{3}$ accumulation rate would be predicted. That is, a diffusion-controlled model predicts that a plot

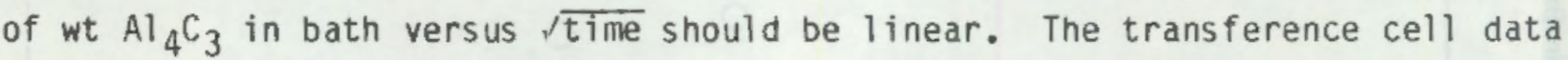
were fitted to this model and results are included as the last two columns in Table 1. Overall, the statistical "goodness-of-fit" favors neither the linear nor parabolic model. Note that the last column of Table 1 represents the wear calculated for the first year of exposure. Figure 5 depicts behavior observed in several of the successful tests. In these cases, parabolic curve fits were somewhat better than linear fits.

Figure 6 summarizes a partially successful test (Test EB-19). Post-test examination of the cell revealed that the crucible cracked sometime during the test. Access of aluminum to the graphite crucible resulted in additional $\mathrm{Al}_{4} \mathrm{C}_{3}$ formation. The $\mathrm{Al}_{4} C_{3}$ results suggest anomalously high formation rates after the 2-h sample was taken. The wear rate of the $\mathrm{TiB}_{2}-\mathrm{G}$ specimen used in this test, based on the few initial data points, is given in Table 1.

Two tests, EB-27 and EB-30, were done with a cryolitic bath ratio of 2.0 and are the only tests in which the amount of $\mathrm{Al}_{4} \mathrm{C}_{3}$ found in bath samples exceeded the equilibrium solubility values. The calculated $\mathrm{Al}_{4} \mathrm{C}_{3}$ saturation values were $0.166 \mathrm{~g}$ and $0.152 \mathrm{~g}$ for $E B-27$ and $E B-30$, respectively. $A 11$ tests other than EB-27 and EB-30 were done with acidic cryolitic baths (bath ratio= 1.07). All samples obtained from these tests had $\mathrm{Al}_{4} \mathrm{C}_{3}$ concentrations at least a factor of five less than saturation.

At a bath ratio of 2.0 , the equilibrium solubility of $\mathrm{Al}_{4} \mathrm{C}_{3}$ is a factor of about 12 less than at a bath ratio of 1.07. During the relatively short duration of these tests, saturation was not reached in the tests with bath ratios of 1.07 . 


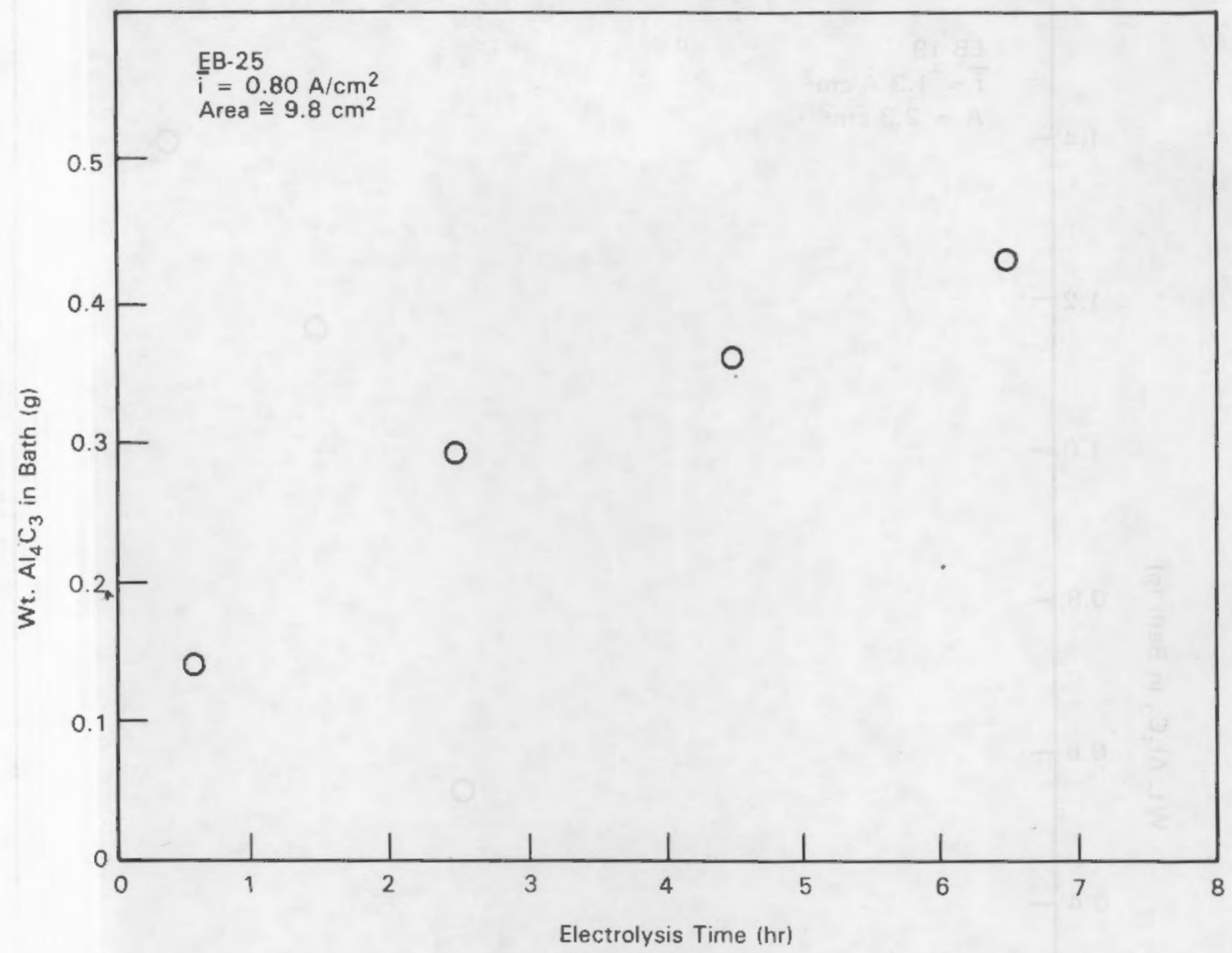

FIGURE 5. Aluminum Carbide Content of Bath as a Function of Electrolys is Time for EB-25

Within the time frame of the high bath ratio tests, the cryolite reached saturation in $\mathrm{Al}_{4} \mathrm{C}_{3}$. As additional $\mathrm{Al}_{4} \mathrm{C}_{3}$ was formed by the reaction of $\mathrm{Al}$ with carbon, resulting $\mathrm{Al}_{4} \mathrm{C}_{3}$ particles may have formed in the bath. The higherthan-saturation values of $\mathrm{Al}_{4} \mathrm{C}_{3}$ found in several samples indicate that both truly dissolved and suspended particles of $\mathrm{Al}_{4} \mathrm{C}_{3}$ were probably included in the samples. The wear mechanism proposed for $\mathrm{TiB}_{2}-\mathrm{G}$ in this study sugges ts that the rate of formation of $\mathrm{Al}_{4} \mathrm{C}_{3}$ is not impeded by the presence of previously formed $\mathrm{Al}_{4} \mathrm{C}_{3}$ in the bath. 


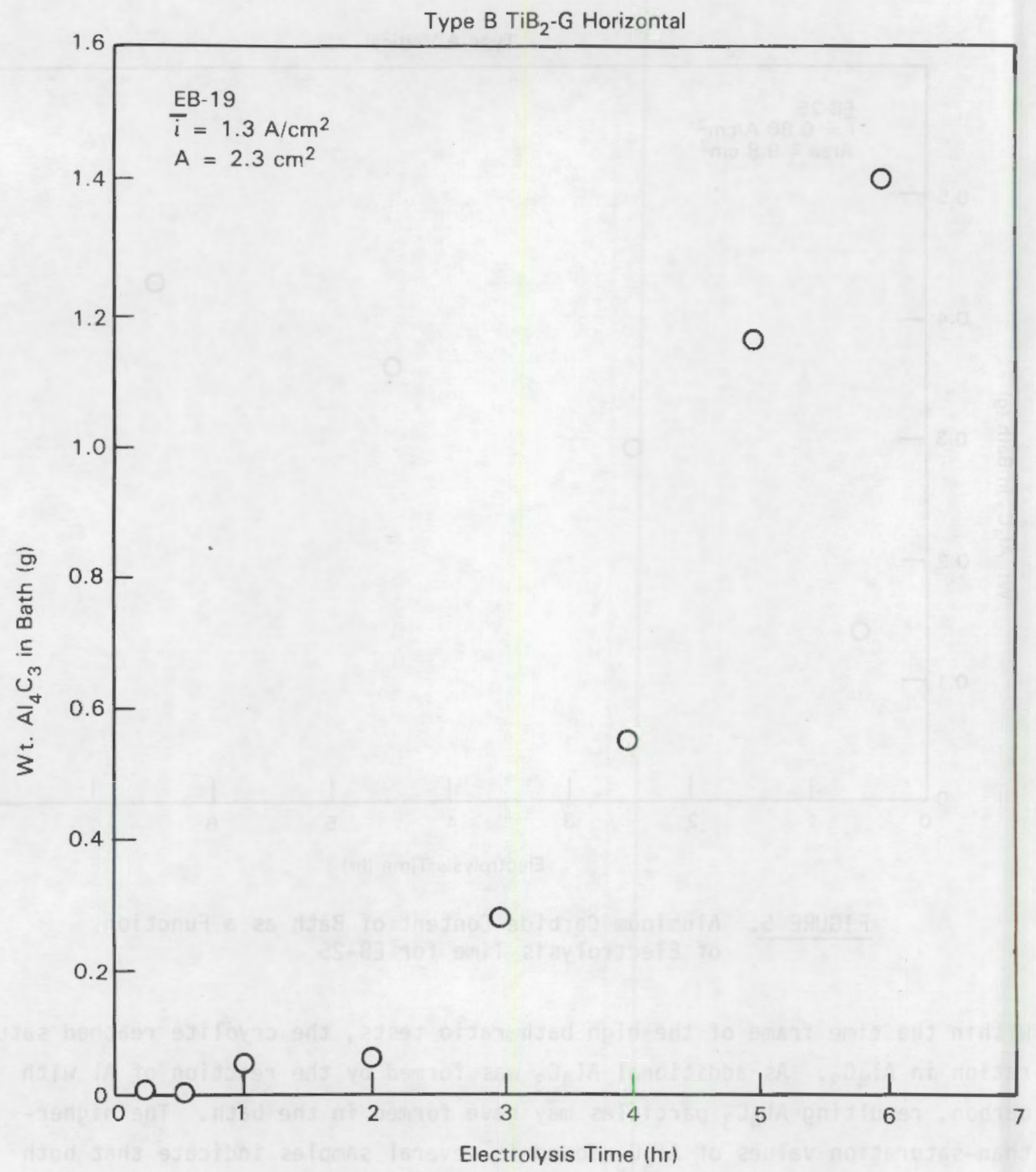

FIGURE 6. Aluminum Carbide Content of Bath as a Function of Electrolys is Time for EB-19 
An alternative way of presenting these data is to estimate the amount of $\mathrm{Al}_{4} \mathrm{C}_{3}$ produced as a fraction of the electrolytically produced $\mathrm{Al}$. If $100 \%$ current efficiency for Al production is assumed, the "current inefficiency" due to formation of $\mathrm{Al}_{4} \mathrm{C}_{3}$ from the primary product ( $\mathrm{Al}$ metal) can be calculated. For the graphite cathode specimen in the horizontal configuration (Test EB-14), a ratio of $80 \mathrm{mg} \mathrm{Al} \mathrm{C}_{3} / \mathrm{g} \mathrm{Al}$ produced was calculated.

For $\mathrm{TiB}_{2}-\mathrm{G}$ specimens under thin film conditions, that is, an exposed vertical surface, a current inefficiency of $13 \pm 4$ (SD) $\mathrm{mg} \mathrm{Al}_{4} \mathrm{C}_{3} / \mathrm{g} \mathrm{Al}$ was estimated. This estimated current inefficiency does not correlate with current density or bath ratio. Within the accuracy of the experimental data, it appears that the initial wear rate of $\mathrm{TiB}_{2}-\mathrm{G}$ under thin film conditions is strongly correlated to the amount of Al metal deposited on it.

During system testing, a graphite specimen was used as a horizontal cathode in the transference cell. This test provided baseline data for the rate of $\mathrm{Al}_{4} \mathrm{C}_{3}$ formation at cathodic graphite not under thick $\mathrm{Al}$ pad conditions. Since molten Al does not wet graphite, simultaneous exposure of the graphite to liquid $A 1$ and molten cryolite took place. The calculated wear rate was $78 \mathrm{~cm} / \mathrm{yr}$. The $\mathrm{Al}_{4} \mathrm{C}_{3}$ content of samples taken during the graphite test is graphically displayed in Figure 7 as a function of time up to $5 \mathrm{~h}$. The test was discontinued after $7 \mathrm{~h} . \mathrm{Al}_{4} \mathrm{C}_{3}$ build-up in the bath was linear with time.

The linear wear rate of carbon under thick pad conditions is known to be about two orders of magnitude less than the value quoted above. This high value is attributed to concomitant production of $\mathrm{Al}$ and $\mathrm{Na}$ at the high current density used in this test $\left(3 \mathrm{~A} / \mathrm{cm}^{2}\right)$. Metallic sodium is known to interculate and weaken graphitic structures leading to accelerated wear. It is not known whether the wear rate would have been reduced if the cell had been operated at a more typical value of about $1 \mathrm{~A} / \mathrm{cm}^{2}$.

\section{METALLOGRAPHIC ANALYSIS}

Both types of $\mathrm{TiB}_{2}-\mathrm{G}$ were soak tested in cryolite for $48 \mathrm{~h}$. After the soak tests, the specimens were sectioned with frozen baths and polished for metallographic analysis and scanning electron microscope (SEM) analys is of the reaction zone. Results of the analyses are described below. 


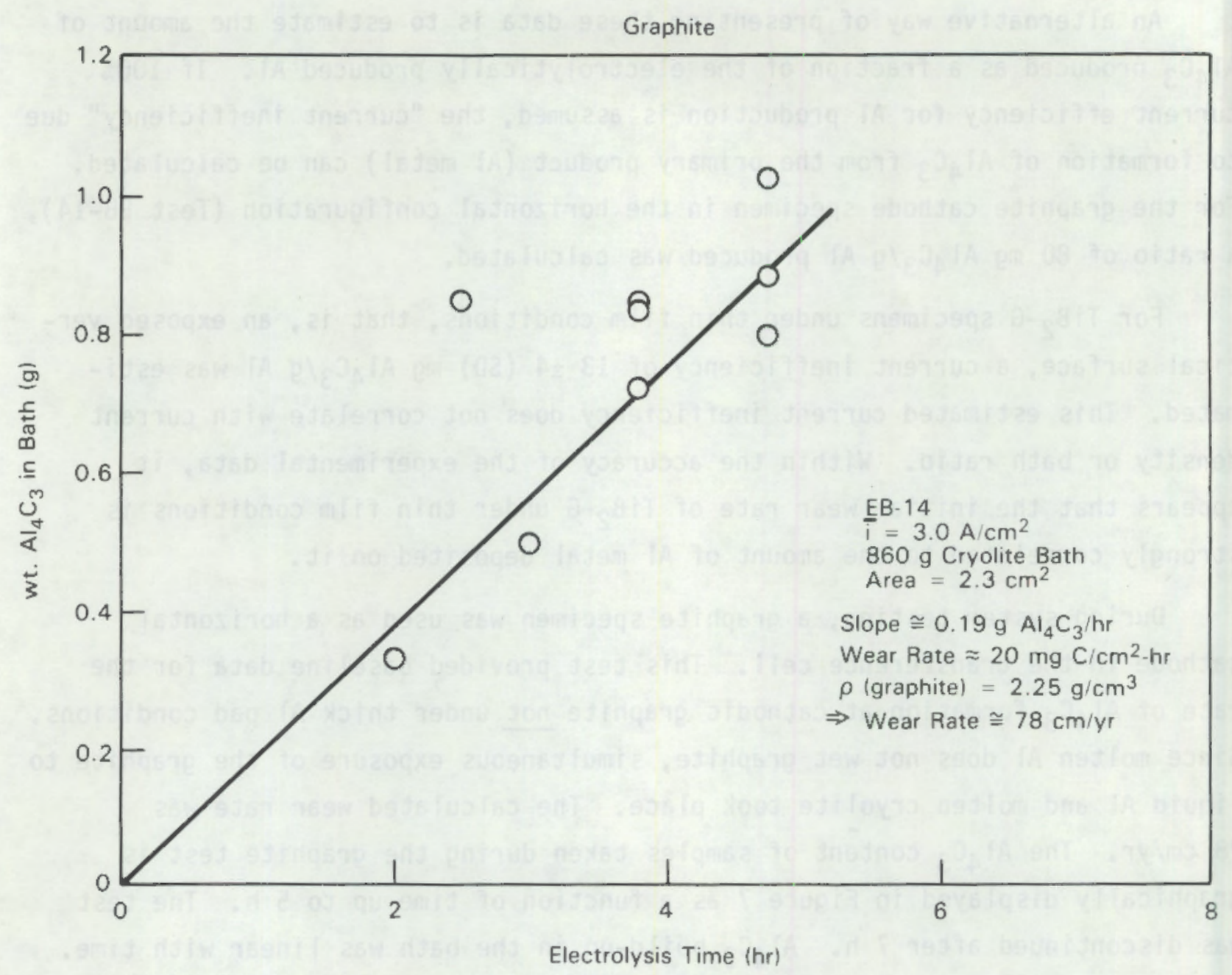

FIGURE 7. Aluminum Carbide Content of Bath as a Function of Electrolysis Time for Test EB-14

\section{Type B Material}

Optical micrographs revealed evidence of some dissolution of the cathode material in the cryolite bath (Figure 8 ). Attack by the cryolite was more evident in the SEM micrographs (Figure 9). The formation of a scale on the $\mathrm{TiB}_{2}-\mathrm{G}$ as well as particles within the bath material can be seen in the SEM micrographs.

Elemental analysis showed that the bright particles in the cryolite were highly Ti enriched (Figure 9c). The morphology of these particles is different from that of the $\mathrm{TiB}_{2}$ particles in the original $\mathrm{TiB}_{2}-\mathrm{G}$. There was a lower 


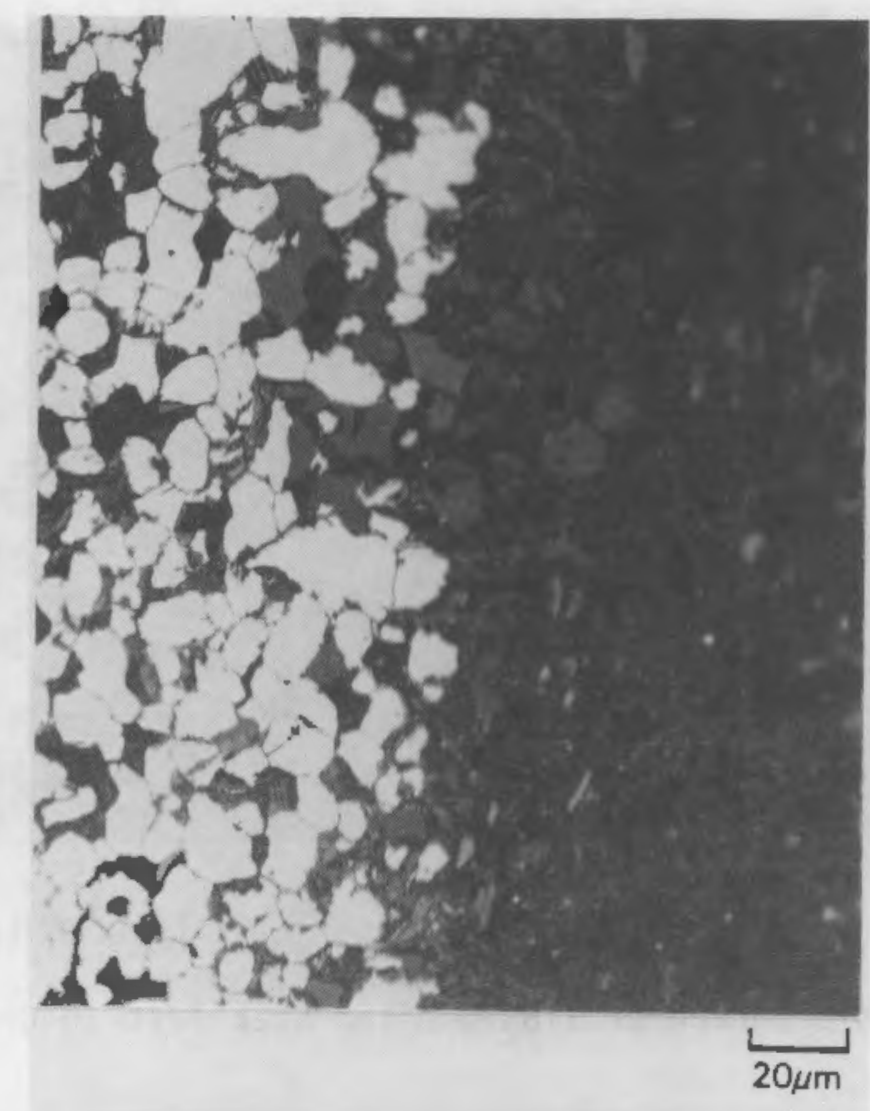

FIGURE 8. Optical Micrograph of Type B TiB $2^{-G}$
After Soak Test in Cryolite

level of $\mathrm{Ti}$ in the scale (reaction product layer between the bath and cathode) compared with the unreacted cathode material. The boron analys is was inconclusive but tended to show low levels in both the scale and the bath. The $\mathrm{TiB}_{2}$ appears to be dissolving, and a Ti-rich phase is forming in the bath that has a nigher $\mathrm{Ti}$ concentration than the $\mathrm{TiB}_{2}-\mathrm{G}$ itself.

Based on these elemental maps, the carbon matrix did not exhibit evidence of attack. The elemental map showed little difference between carbon in the scale or in the matrix (Figure 9d). Overlapping the elemental maps of $\mathrm{Al}$ and $\mathrm{C}$ did not show the presence of $\mathrm{Al}_{4} \mathrm{C}_{3}$.

The $\mathrm{Na}, \mathrm{Al}, 0$, and $\mathrm{Si}$ maps were all similar. All showed the penetration of cryolite into the $\mathrm{TiB}_{2}-\mathrm{G}$ matrix (Figure 9e). The high silicon content comes from the quartz crucible used in the test. The bath material migrated through the pores and interstices in the $\mathrm{TiB}_{2}-\mathrm{G}$. Evidence of bath was found up to 


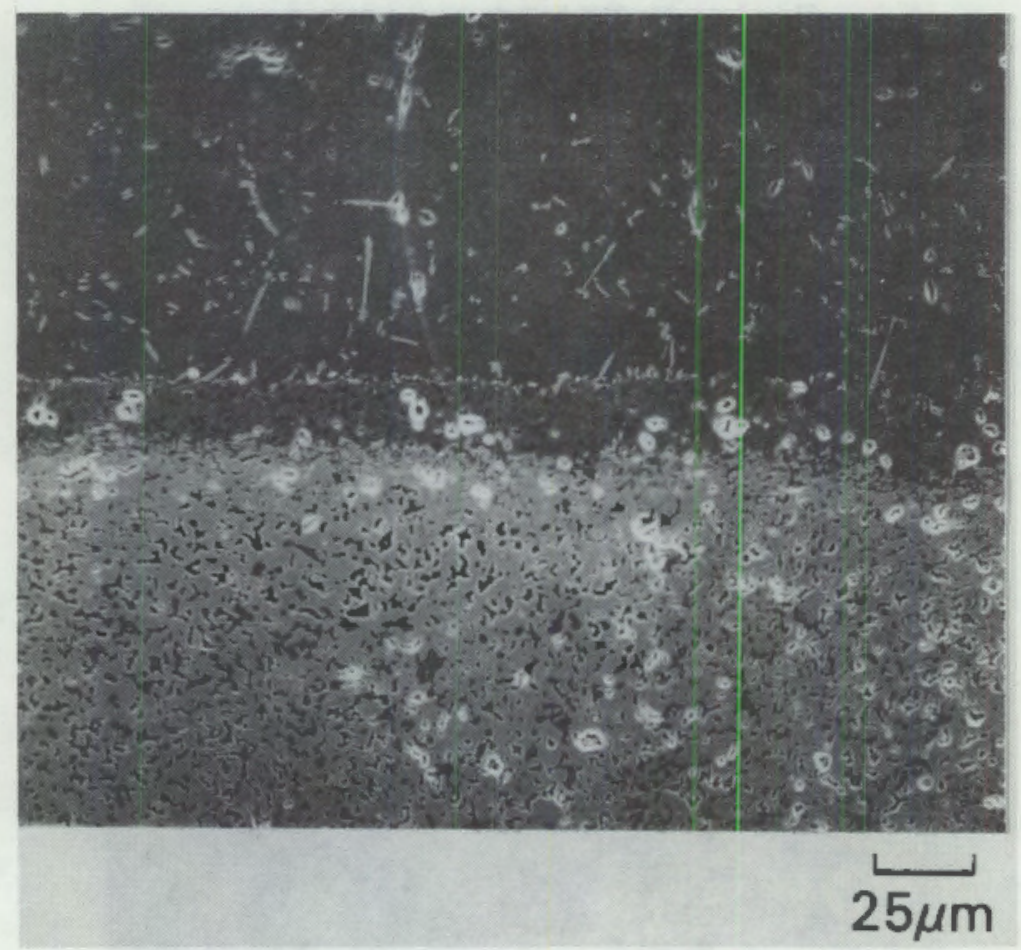

a) SEM Micrograph of $\mathrm{TiB}_{2}-\mathrm{G}$ After Soak Test in Cryolite

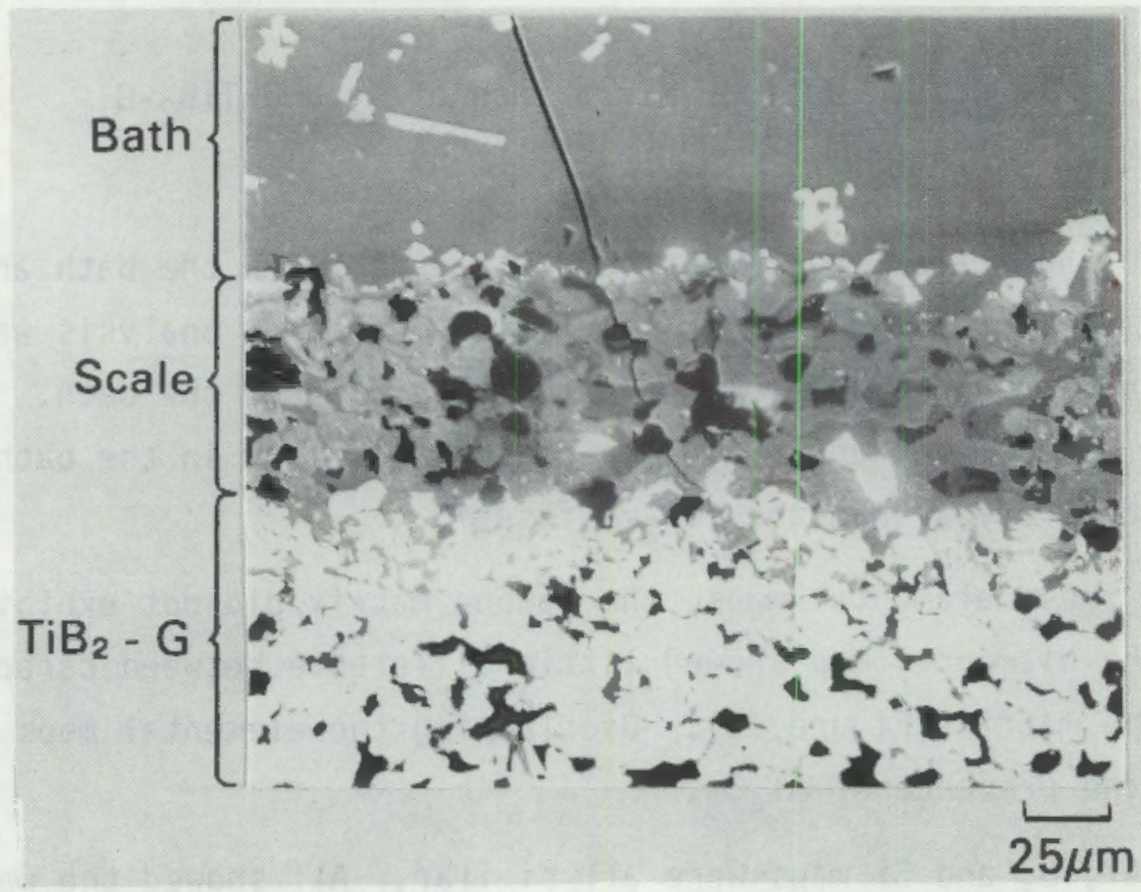

b) Backscattered Electron Micrograph of Scale Region

FIGURE 9. Elemental Maps of Type B TiB 2 -G After Soak Testing in Cryolite 


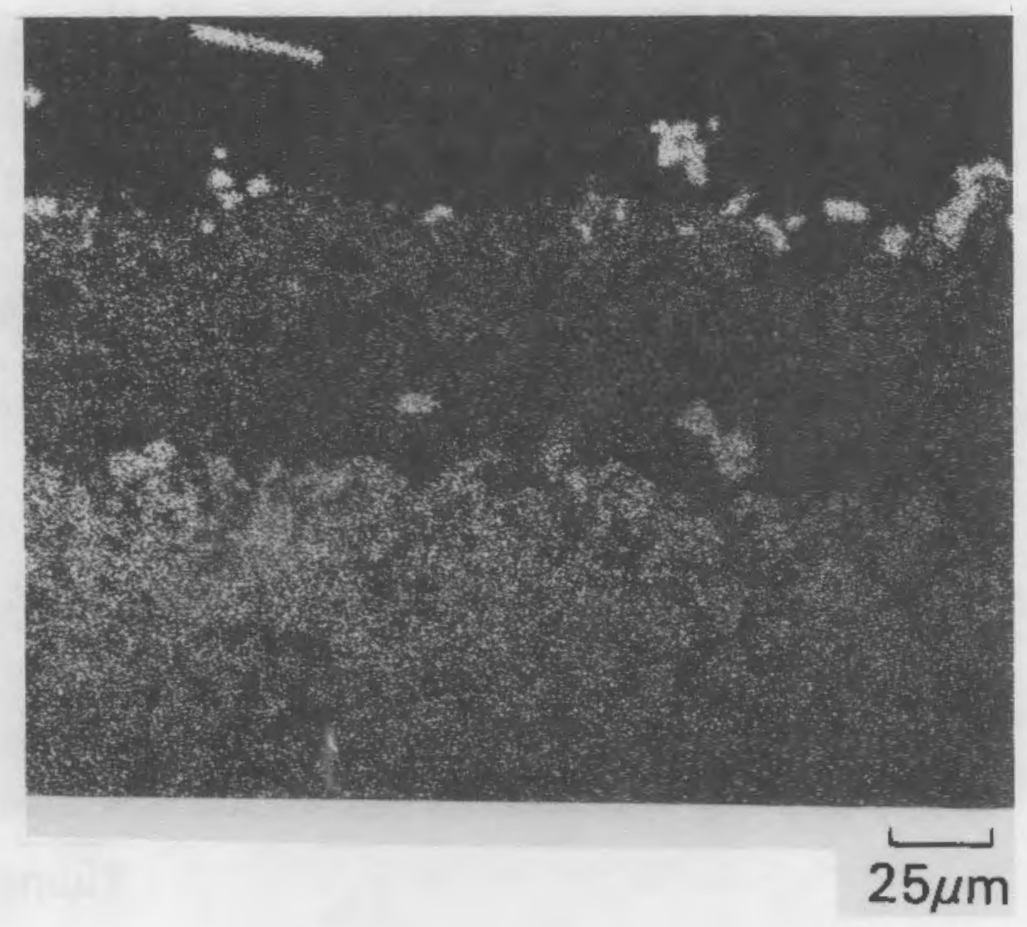

c) Ti Elemental Map of Scale Region

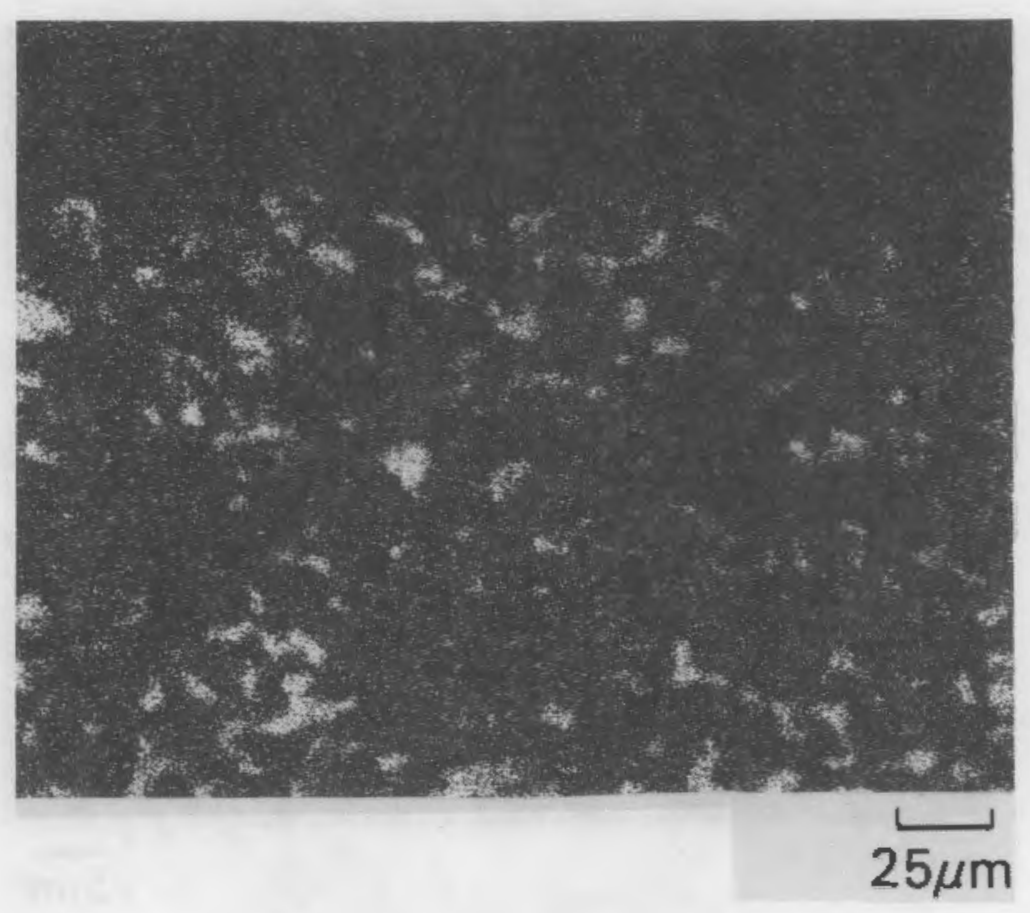

d) C Elemental Map of Scale Region

FIGURE 9. (contd) 


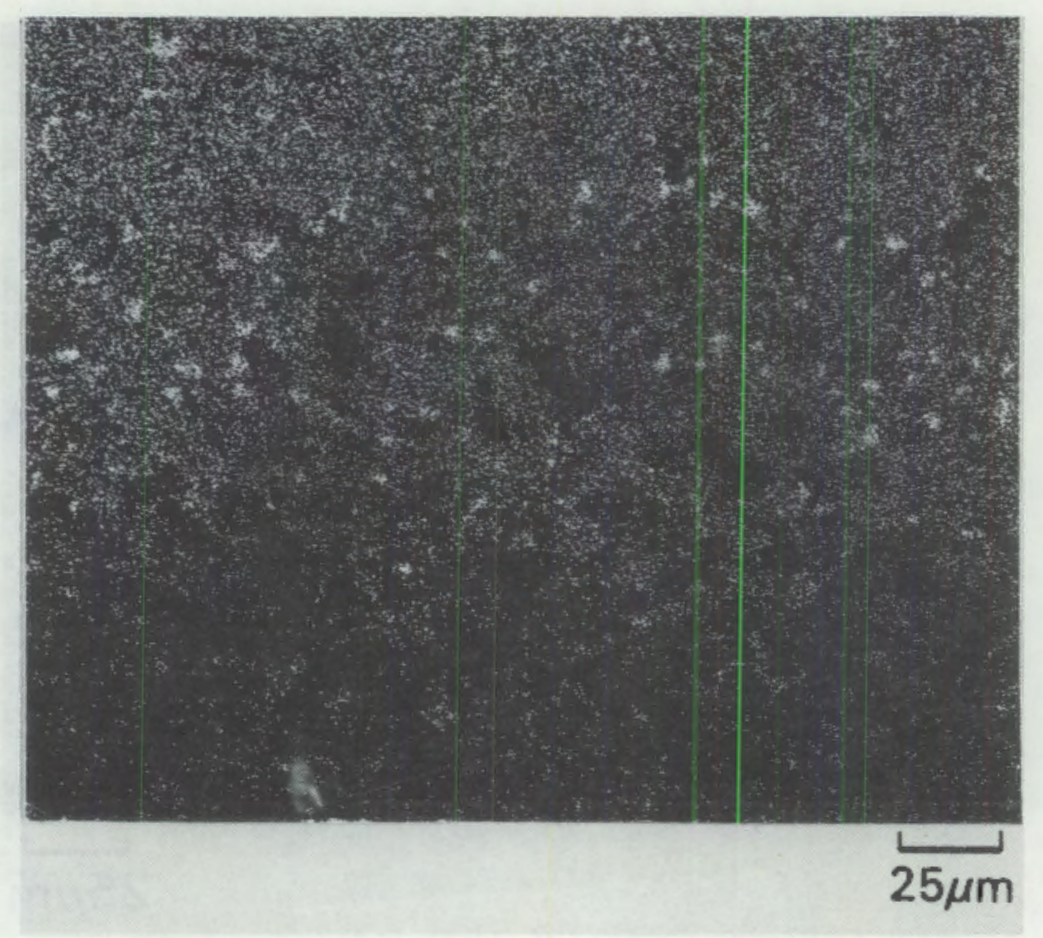

e) Al Elemental Map of Scale Region ( $\mathrm{Si}, \mathrm{Na}, 0$ maps are similar)

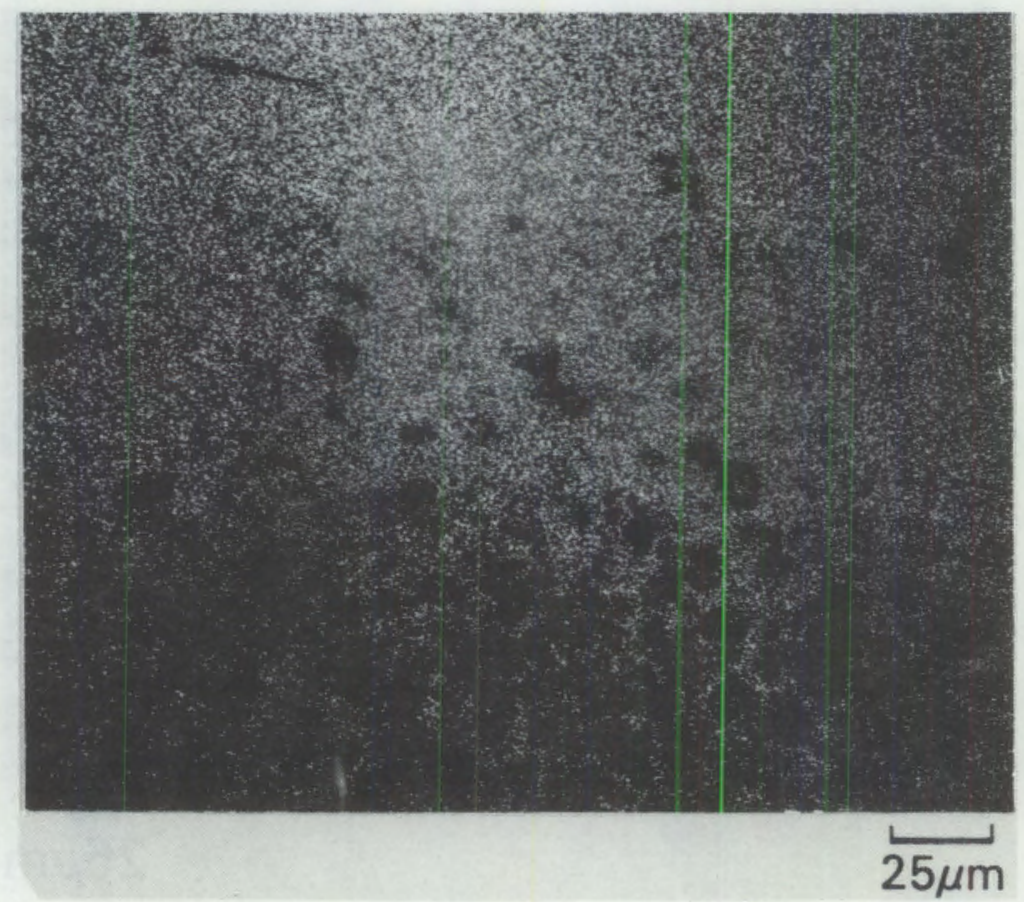

f) F Elemental Map of Scale Region

FIGURE 9. (contd) 
$0.25 \mathrm{~mm}$ from the original interface. Fluorine, in general, behaved similarly to $\mathrm{Na}$ except that occasional high concentrations of $\mathrm{F}$ were found (Figure $9 f$ ). These tended to be concentrated in the scale. The explanation for this high fluorine concentration in not known.

Based on the above analysis, the cryolite penetrated the $\mathrm{TiB}_{2}-\mathrm{G}$ through the porous network. Concurrently, it was dissolving (reacting with) the $\mathrm{TiB}_{2}$ to form some complex Ti/cryolite mixture in the scale. Some of the titanium apparently reprecipitated, probably upon cooling, in the bath near the scale. These precipitates had a different morphology than the original $\mathrm{TiB}_{2}$ and were highly Ti enriched.

\section{Type A Material}

The general appearance of the reaction zone in Type A material after a cryolite soak was similar to that in Type B. Backscattered electron micrographs, which reveal compositional variations, show an apparent bilayer scale (Figure 10). The outer scale may be somewhat atypical and may be due to the

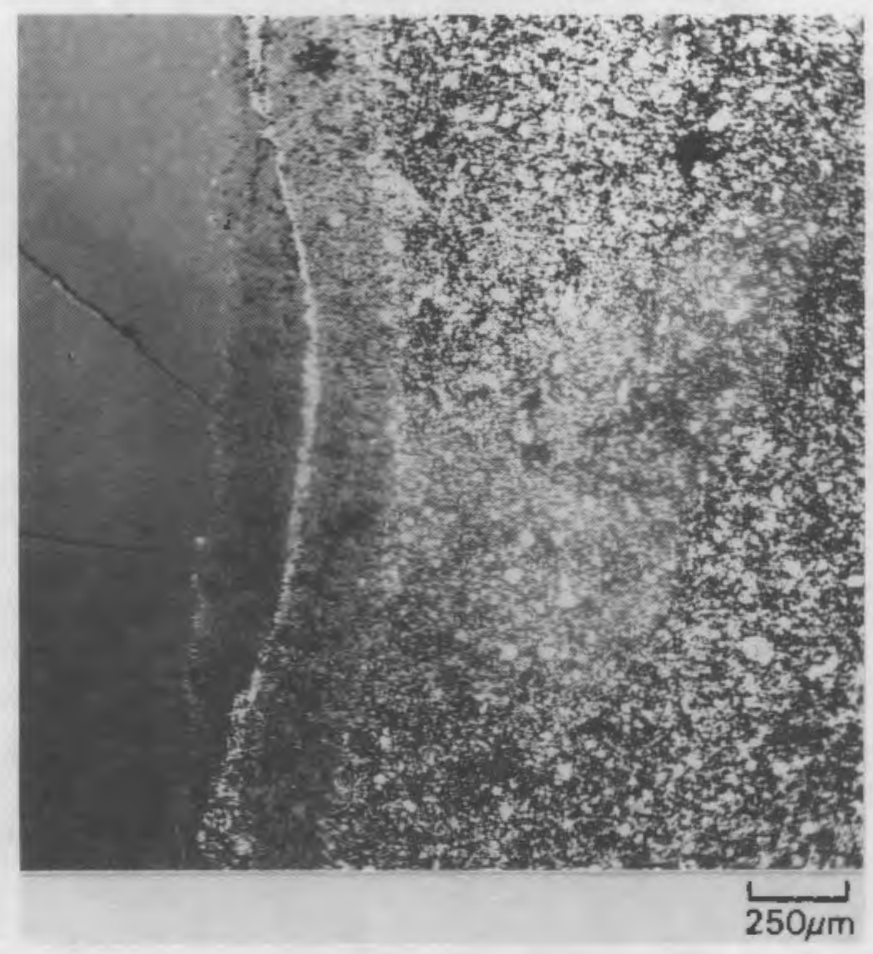

FIGURE 10. Backscattered Electron Micrograph Showing Compositional Variation in Reaction Zone of Type A Material 
indentation at the point examined, allowing bath material to be trapped near the $\mathrm{TiB}_{2}-\mathrm{G}$ surface. An enlargement of the scale adjacent to the $\mathrm{TiB}_{2}-\mathrm{G}$ is shown in Figure 11.

Elemental mapping clearly showed the bright band to be highly Ti rich (Figure 12). This band is analogous to the isolated particles seen on the edge of the scale in Type B material. There was also a much lower concentration of $\mathrm{Ti}$ in the scale. The Ti-rich band could be pure $\mathrm{Ti}$ since a boron map showed no boron present in this band (Figure 13). It is suggested that boron is lost due to the reaction of $\mathrm{TiB}_{2}$ with cryolite and subsequent loss of volatile reaction product $\mathrm{BF}_{3}$. Hence, boron is lost from the bath.

The carbon elemental map showed little effect on the carbon phase. The carbon is relatively uniform in the Ti-rich band as well as in the scale and matrix. The cryolite is apparently only attacking the $\mathrm{TiB}_{2}$.

Sodium, aluminum, and silicon had similar elemental maps; they generally occur in the same phase. There appeared to be somewhat less penetration of the bath into the matrix in Type $A$ material than in Type B, which was somewhat

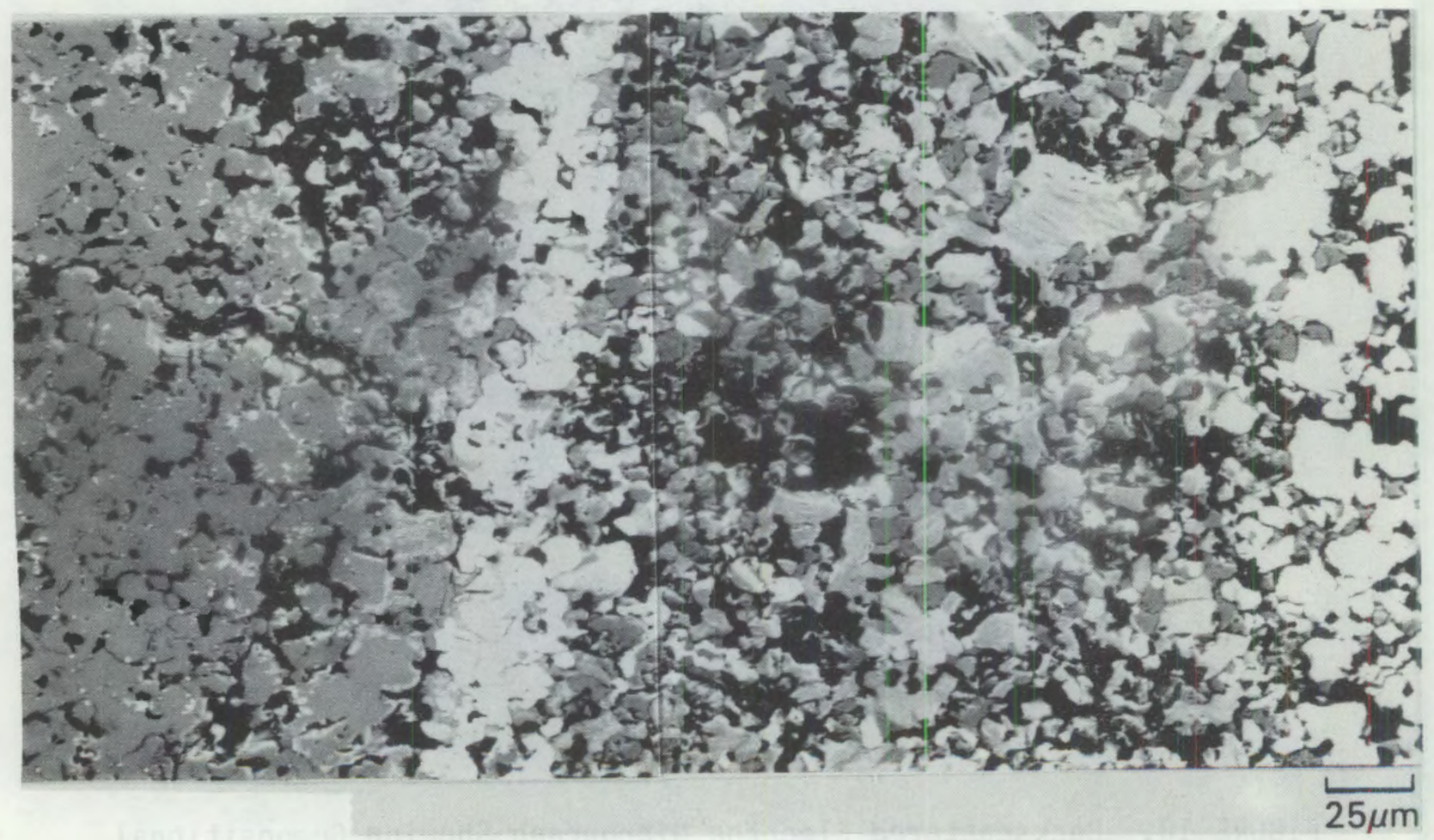

FIGURE 11. Enlargement of Scale Region Shown in Figure 10 


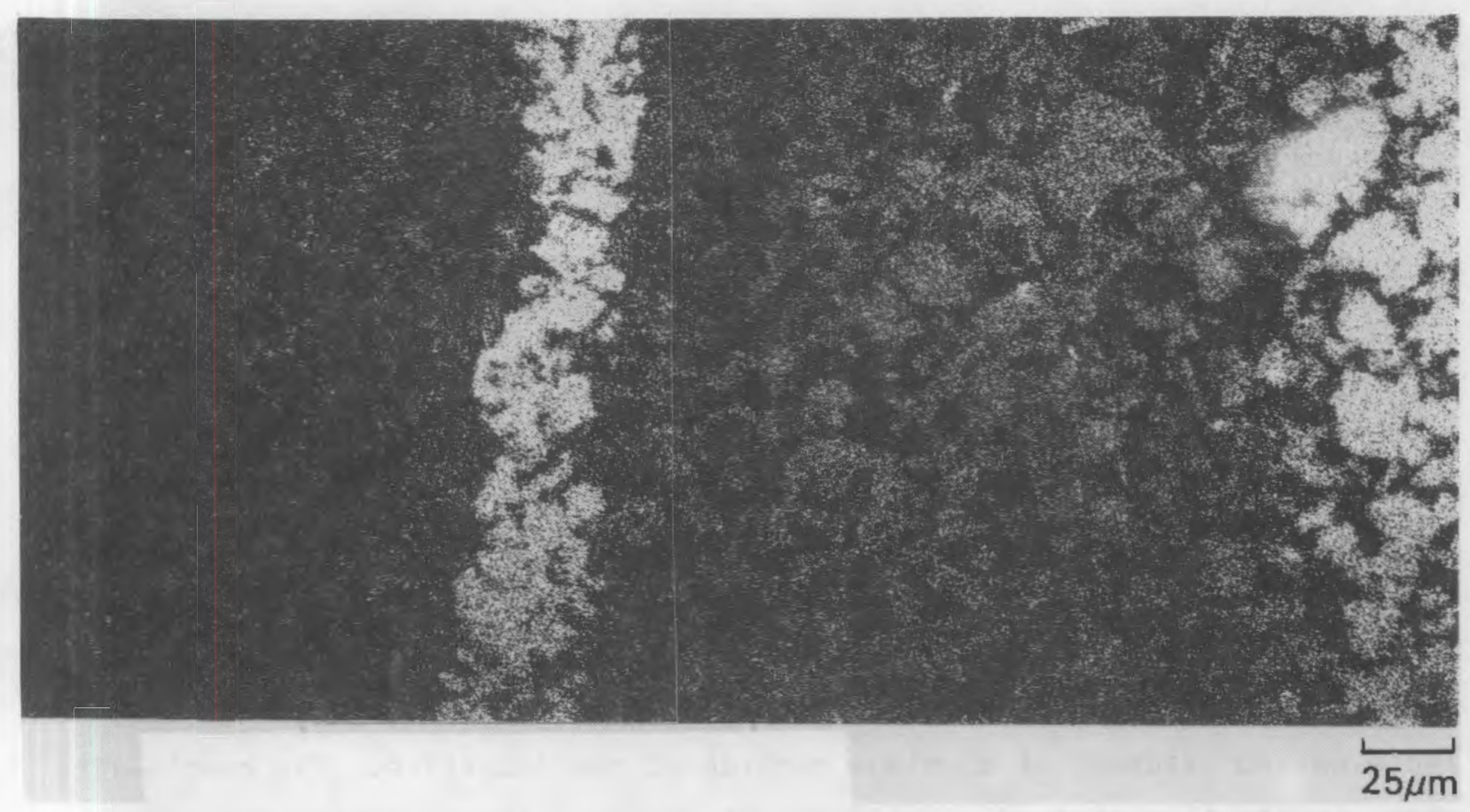

FIGURE 12. Ti Elemental Map Showing High Ti Concentration with Light Band at Edge of Scale $\left(\mathrm{TiB}_{2}\right.$ matrix is at far right)

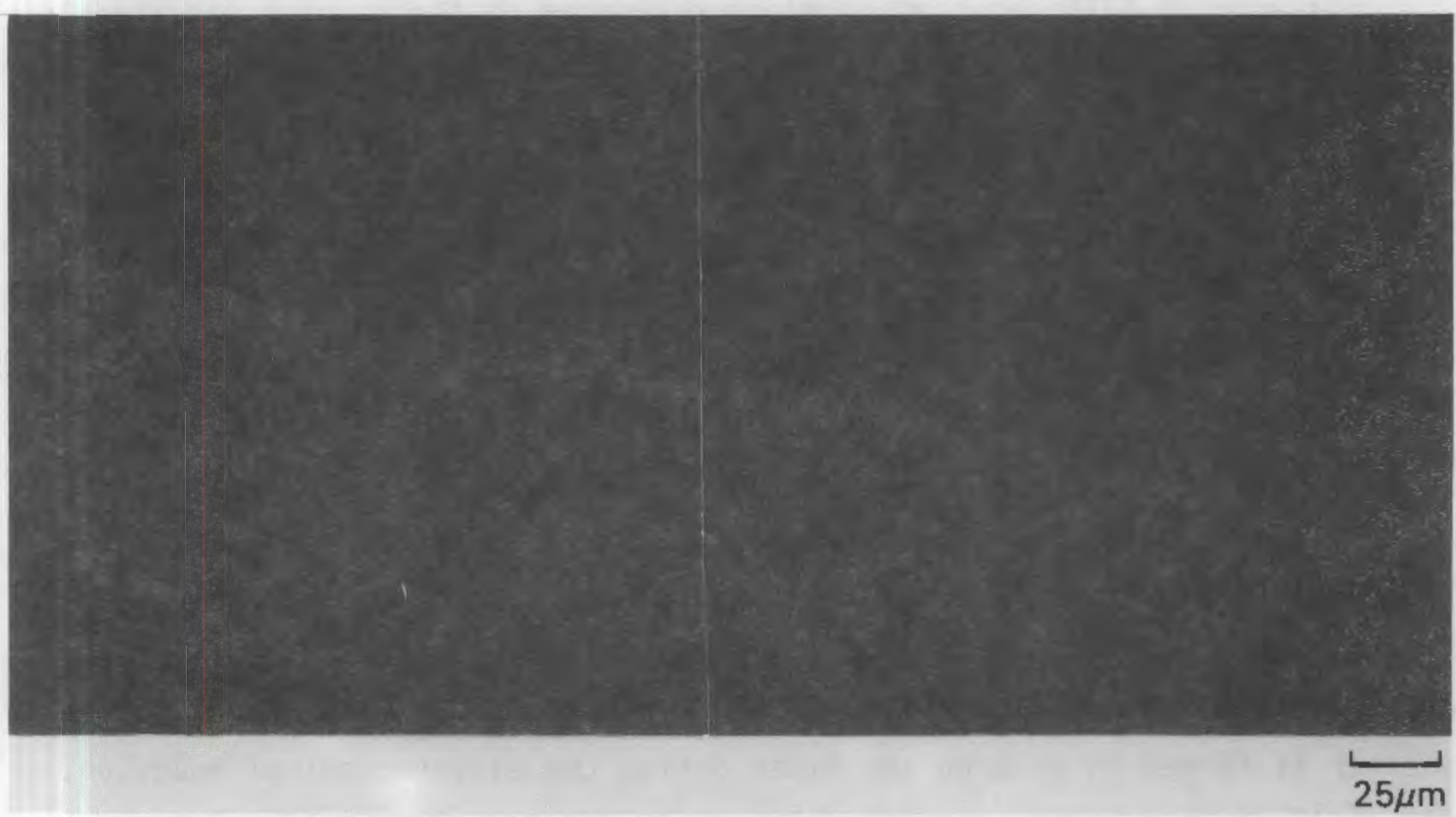

FIGURE 13. B Elemental Map. $B$ is only observed in the $\mathrm{TiB}_{2}$ matrix at the far right. 
surprising since Type A material seems to have more porosity. Within the scale regions, regions of higher sodium concentration indicated that several different cryolytic phases formed.

METALLOGRAPHIC AND SEM ANALYSIS OF TiB ${ }_{2}-\mathrm{G}$ TESTED IN A TRANSFERENCE CELL

Horizontal Cathodes

Figure 14a shows a cross section of the Al typically deposited on a horizontal $\mathrm{TiB}_{2}-\mathrm{G}$ specimen $(E B-16)$. This specimen is Type $A T_{i} B_{2}-G$ subjected to 4-1/2 h of electrolysis. In Figure 14b, the enlargement of Region A in Figure $14 \mathrm{a}$ shows that the $A 1$ is separated from the $\mathrm{TiB}_{2}{ }^{-G}$ substrate. Cryolite was observed clinging to the $A 1$. Cryolite had also penetrated into the $\mathrm{TiB}_{2}-\mathrm{G}$. In fact, traces of cryolite were observed near the center of the $\mathrm{TiB}_{2}{ }^{-\mathrm{G}}$ specimen. There was no evidence of aluminum carbide at the interface. The needle-like phase in the Al contained significant $\mathrm{Ti}$ and $\mathrm{Zr}$. The $\mathrm{Zr}$ could have come from the ceramic cement used in mounting the test specimen. There was only a small amount of this phase in the deposited $\mathrm{Al}$.

Evidence of bath penetration along the sides of the cathode was clearly observed. Backscattered electron images show that the gray needle-like phase near the $\mathrm{TiB}_{2}-\mathrm{G}$ is rich in $\mathrm{Al}$. Elemental maps of $\mathrm{Al}, \mathrm{C}$, and 0 indicated that it is aluminum oxide and not aluminum carbide. Cryolite bath was evident in the interstices between the oxide particles as well as in the $\mathrm{TiB}_{2}{ }^{-G}$ matrix, as shown by the elemental $\mathrm{Na}$ map. The oxide phase was also found at the bottom of the cathode in Region $C$. The oxide phase was also present in the region of the Al/bath interface. It probably formed during the cooling of the bath. This oxide phase was rarely observed after a soak test.

In Test EB-19, interfacial interactions were similar to those in Test EB-16 except that $A 1$ appears to have flowed down the sides and down a crack in the center of the $\mathrm{TiB}_{2}-\mathrm{G}$ (Figures 15 and 16). It is not certain whether the Al flowed in a molten state down the sides of the cathode or whether it formed in situ on the sides during the electrochemical reaction. Figure 16 shows a higher magnification of Region $\mathrm{A}$ in Figure 15. TiB 2 particles are imbedded in the $A 1$. The aluminum oxide particles are present near the $\mathrm{Al} /$ bath interface. The $\mathrm{Zr}-\mathrm{Ti}$-rich phase was also present in the deposited Al. 


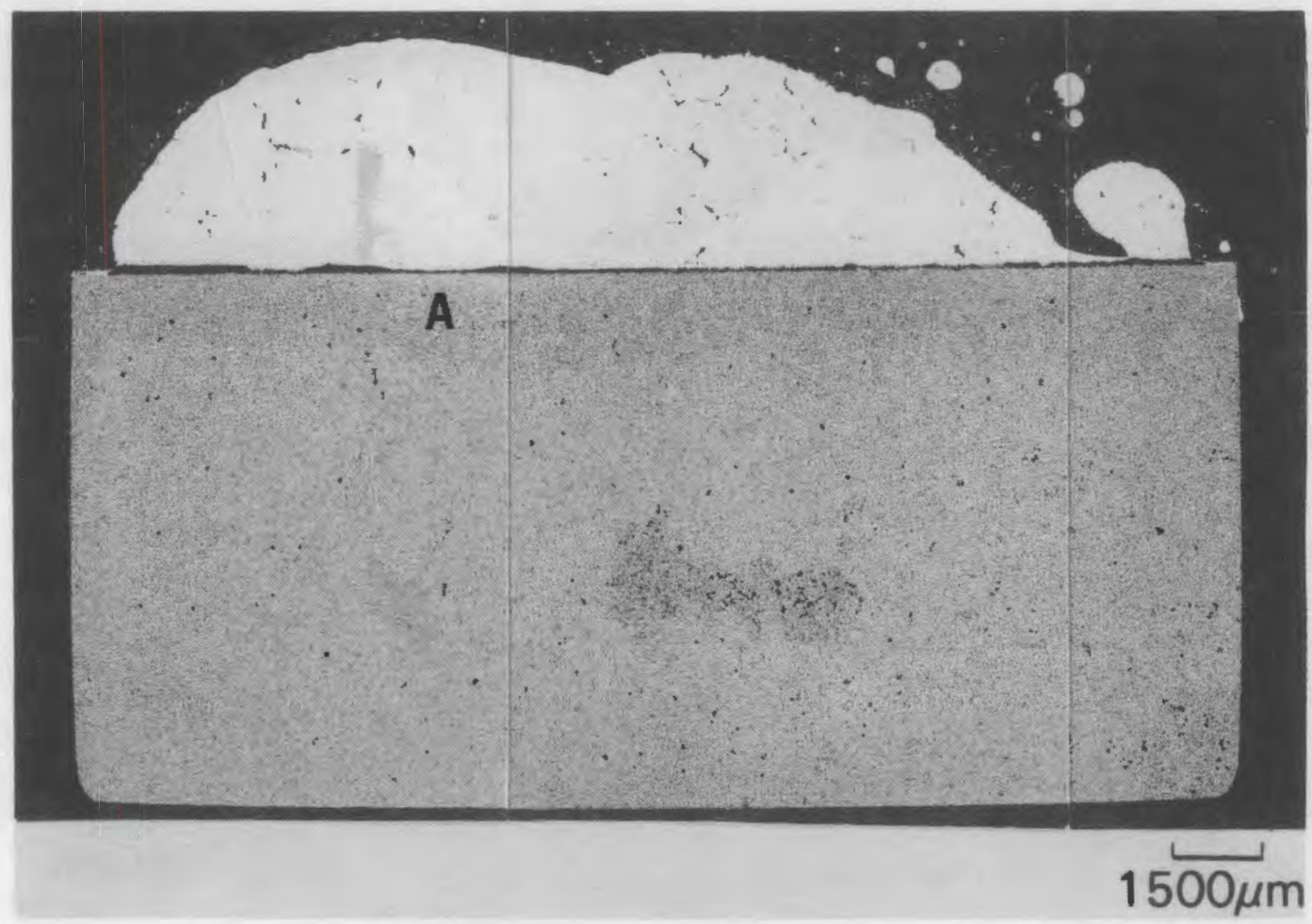

a) Cross section

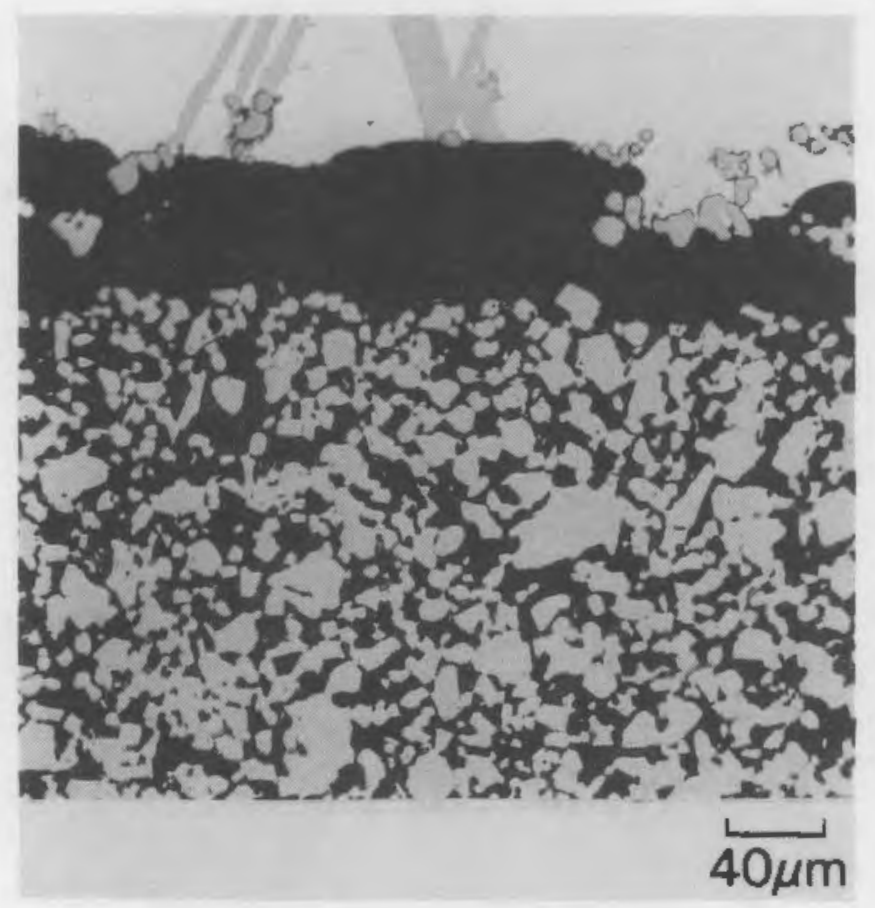

b) Enlargement of Region A

FIGURE 14. Al Deposited on Type A TiB $2-G$ Cathode in Test EB-16 


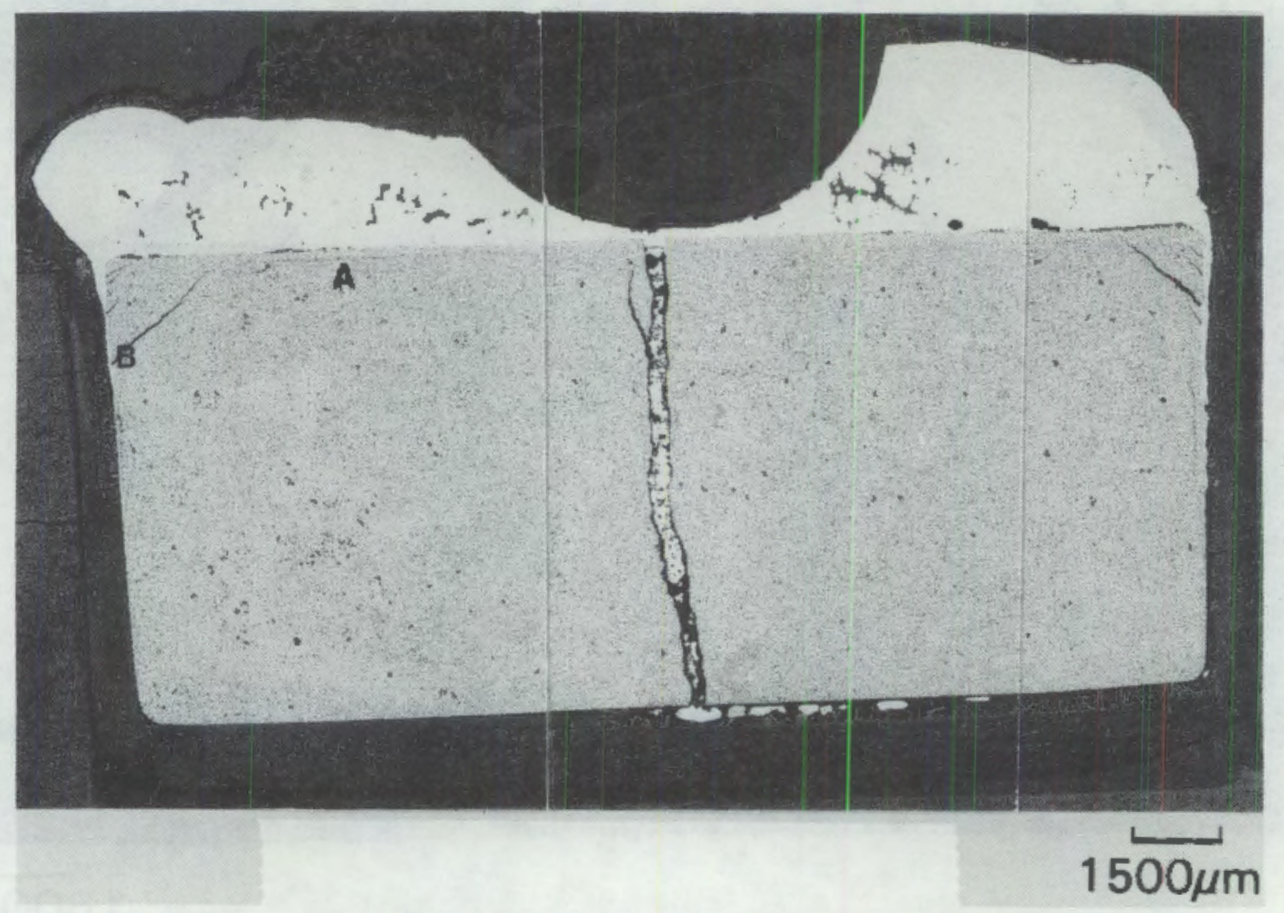

FIGURE 15. Cross Section of Al Deposited on $\mathrm{TiB}_{2}-\mathrm{G}$ Cathode in Test EB-19

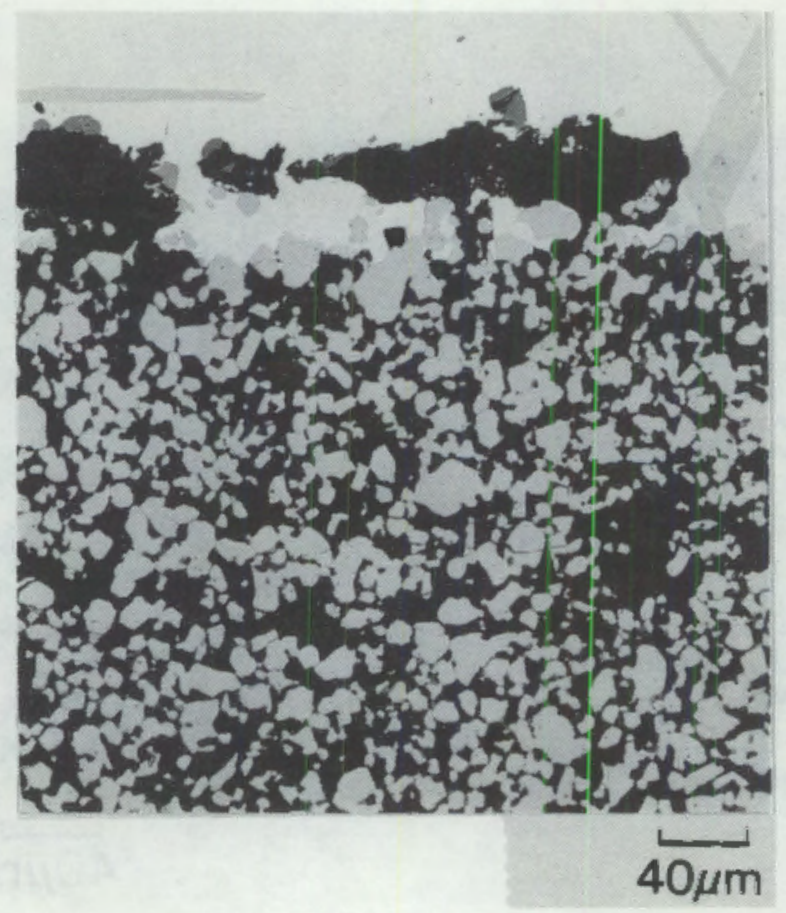

FIGURE 16. Magnification of Region A in Figure 15 
In Region $B$, the $A l$ had penetrated into the $\mathrm{TiB}_{2}-\mathrm{G}$ matrix (Figure 17). The aluminum oxide particles formed near the Al. These particles were never seen within the $\mathrm{TiB}_{2}-\mathrm{G}$ even though bath was present within the cathode material. In neither Region $A$ nor $B$ is there evidence for an aluminum carbide phase.

The deposited $\mathrm{Al}$ adhered to the $\mathrm{TiB}_{2}-\mathrm{G}$ substrate in Test $\mathrm{EB}-18$ much better than in the others discussed (Figure 18). However, bath material was always evident in the $\mathrm{TiB}_{2}-\mathrm{G}$ matrix at every region. Figure 19 shows a higher magnification of Region A in Figure 18 in which $\mathrm{TiB}_{2}$ particles (very light gray) are imbedded in the Al (white area). These $\mathrm{TiB}_{2}$ particles could have become

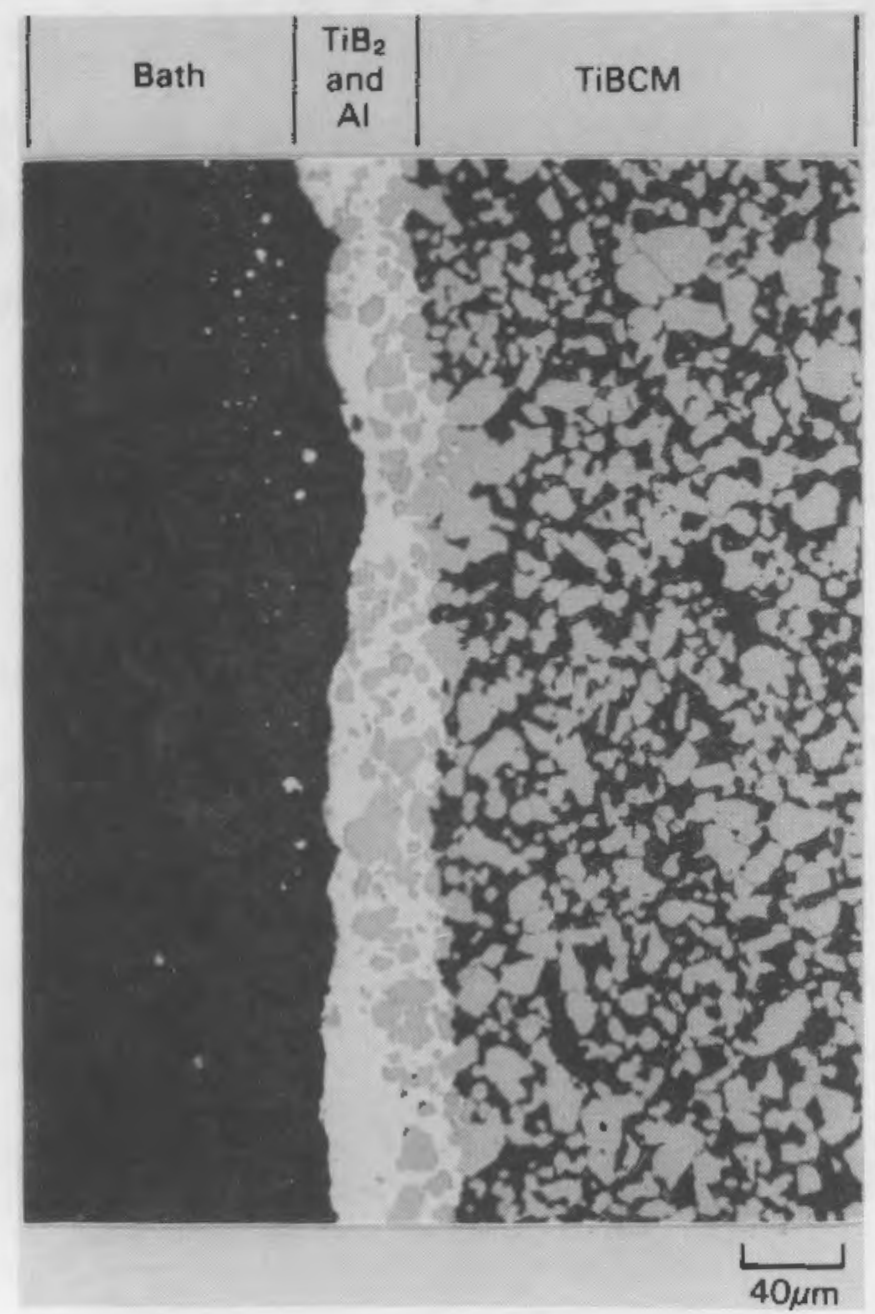

FIGURE 17. Magnification of Region B in Figure 15 


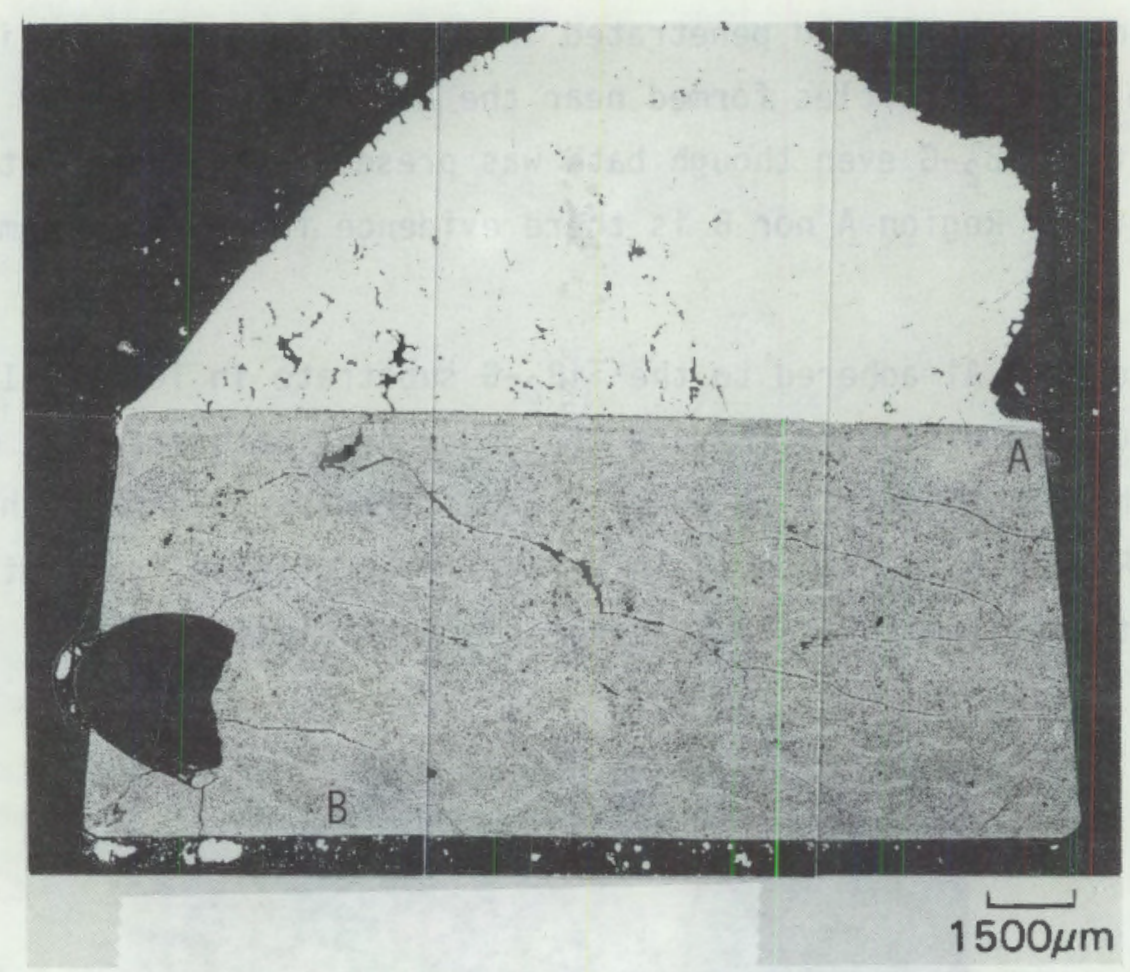

FIGURE 18. Cross Section of Al Deposited on $\mathrm{TiB}_{2}-\mathrm{G}$ Cathode in Test EB-18

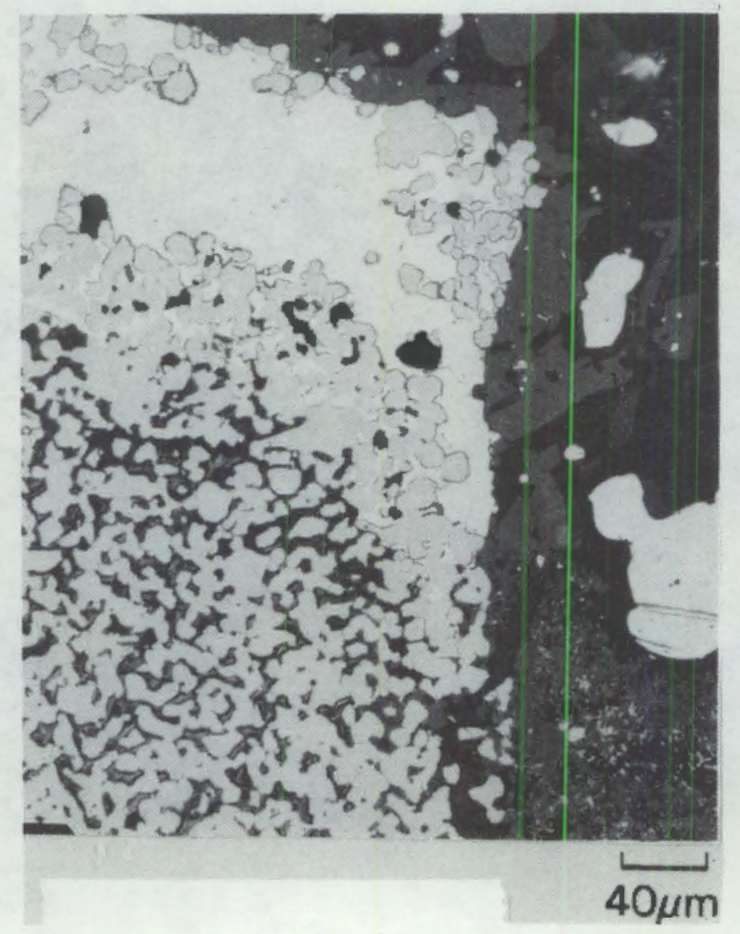

FIGURE 19. Magnification of Region A in Figure 18 
mechanically dislodged from the $\mathrm{TiB}_{2}-\mathrm{G}$ as the aluminum carbide was formed by the reaction of $A 1$ with carbon in the $\mathrm{TiB}_{2}-\mathrm{G}$ matrix. The aluminum oxide (gray needle-1ike structure) phase was again present near the A1. The oxide phase was never present between the $\mathrm{TiB}_{2}-\mathrm{G}$ and the $\mathrm{Al}$.

Vertical Cathodes

In the EB-26 test (Figure 20), there appears to be no interaction between the $A 1$ and the $T i B_{2}$ particles. Rather, the $A l$ replaced the original carbonaceous matrix. As a result, there was an adherent layer of $A$ l on the cathode.

As on the other cathodes tested, the Al formed or flowed along the sides of the cathodes. The appearance of the interface at Region B was very similar to that at the bottom surface of the cathode in Figures 21 and 22 . The needlelike aluminum oxide particles were also present in the frozen bath near the Al layer.

Test conditions for EB-26 consisted of $8 \mathrm{~h}$ of electrolysis in a bath with a bath ratio $=2.0$ using Type $A \mathrm{TiB}_{2}-\mathrm{G} . \mathrm{Al}_{4} \mathrm{C}_{3}$ results obtained from samples taken during electrolysis were erratic due to sampling difficulties and are not reported.

Micrographs of the cathode reaction layer from Test EB-20 are shown in Figures 23 and 24. In Test EB-20, a Type B specimen was subjected to electrolysis at $1 \mathrm{~A} / \mathrm{cm}^{2}$ for $1-1 / 2 \mathrm{~h}$. The test was terminated due to failure of the cathode lead connection; therefore, test results are not included in Table 1. As in previous examples, there appears to be a multitude of discrete $\mathrm{TiB}_{2}$ particles suspended in the electrolytically formed Al. In Figure 24, one can see what may be an $\mathrm{Al}_{4} \mathrm{C}_{3}$ phase between the $\mathrm{TiB}_{2}-\mathrm{G}$ and the $A 1 / T i B_{2}$ surface layer. This is the only evidence for a reaction product, which might be $\mathrm{Al}_{4} \mathrm{C}_{3}$. The composition of this phase was not analyzed using microprobe techniques. 


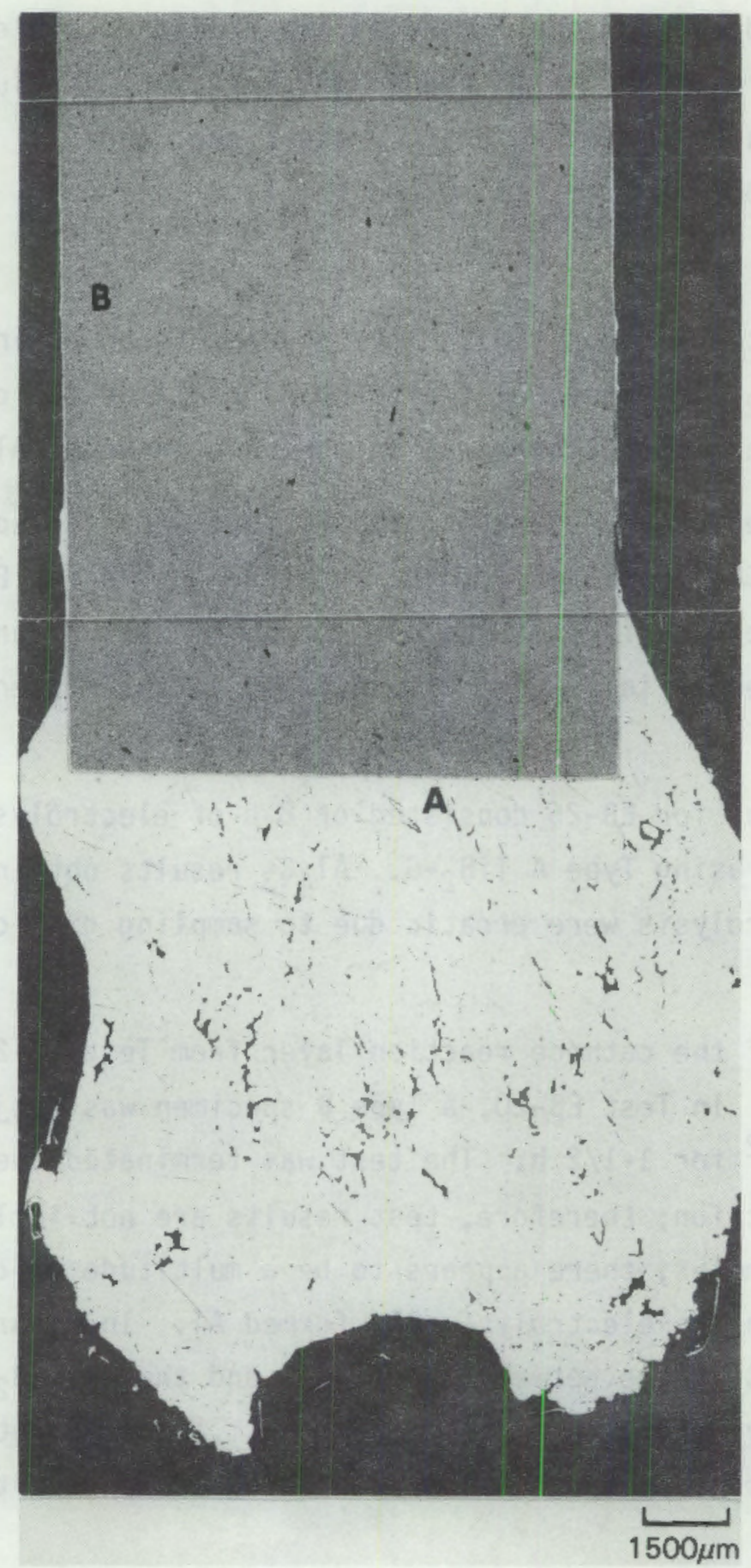

FIGURE 20. Type B Cathode Tested in the Vertical Position in Test EB-26 


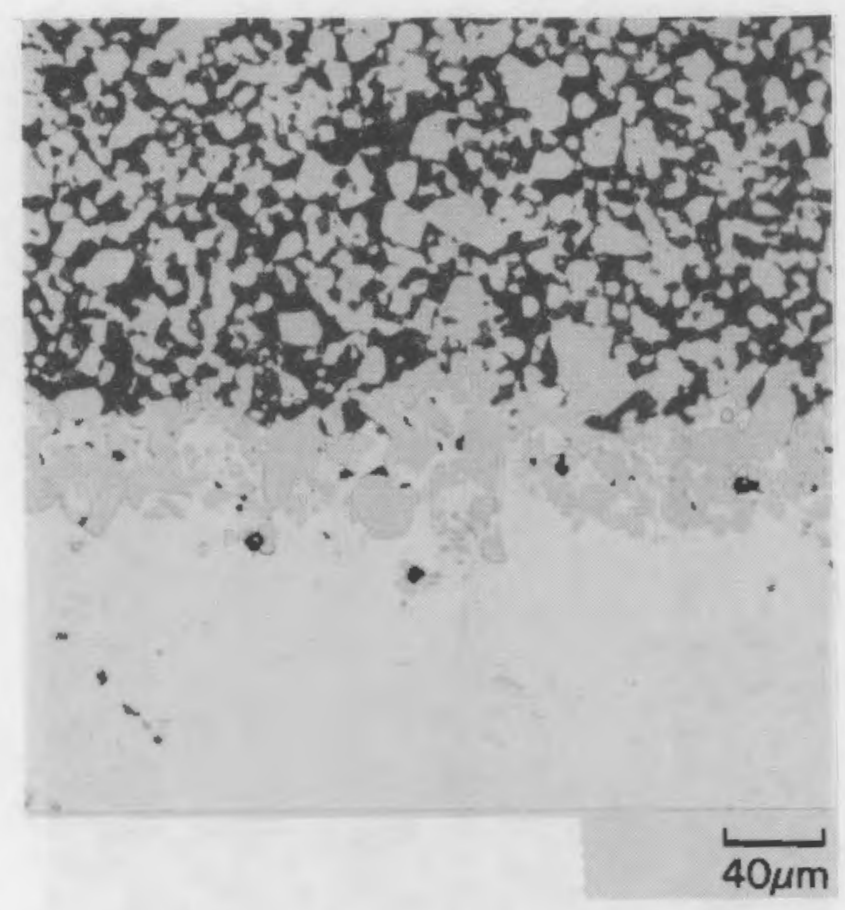

FIGURE 21. Magnification of Region A in Figure 20

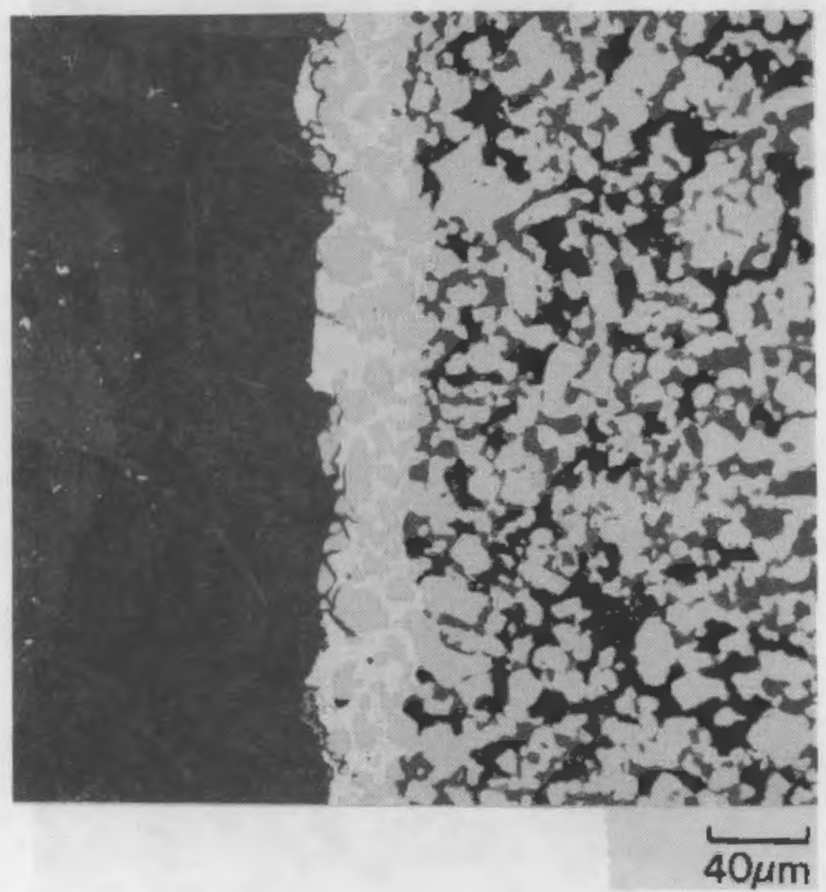

FIGURE 22. Magnification of Region B in Figure 20 


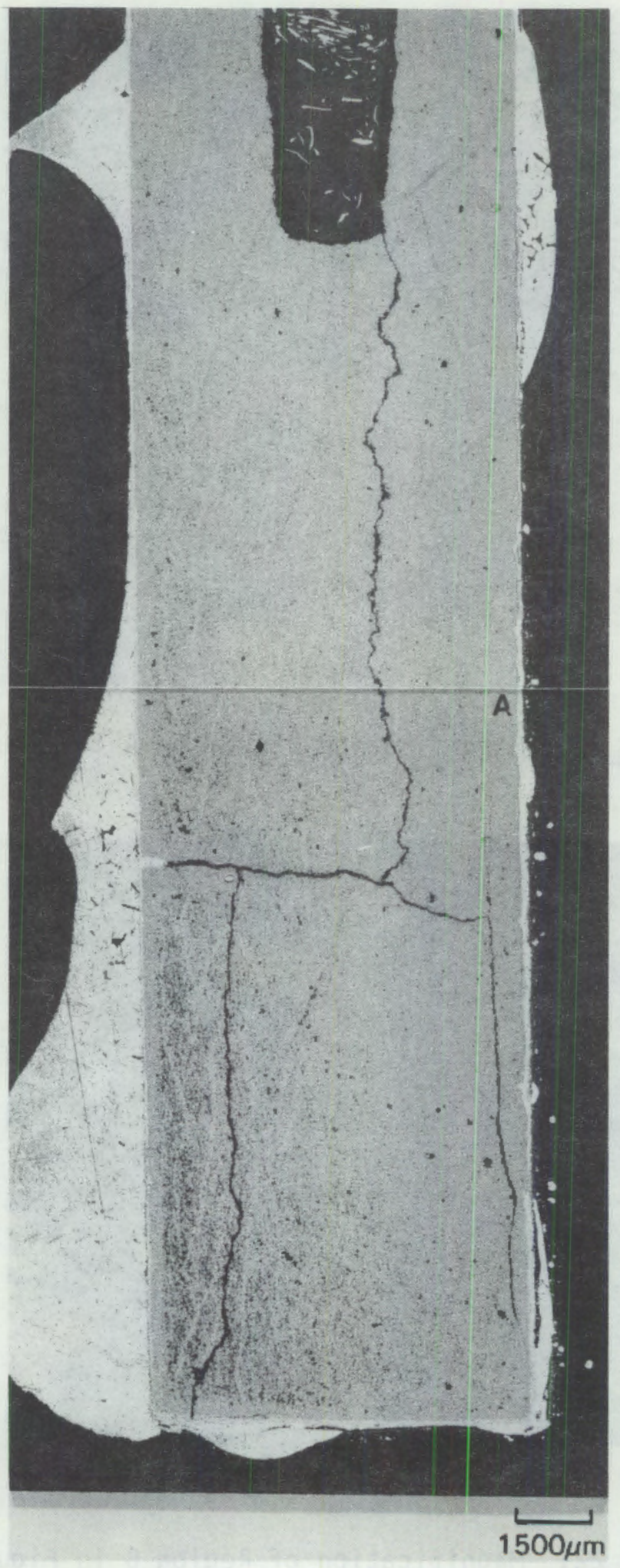

FIGURE 23. Cross Section of Al Deposited on $T i B_{2}-G$ in Test EB-20. $\mathrm{An} \mathrm{Al}_{4} \mathrm{C}_{3}$ phase may be present at region $A$. 


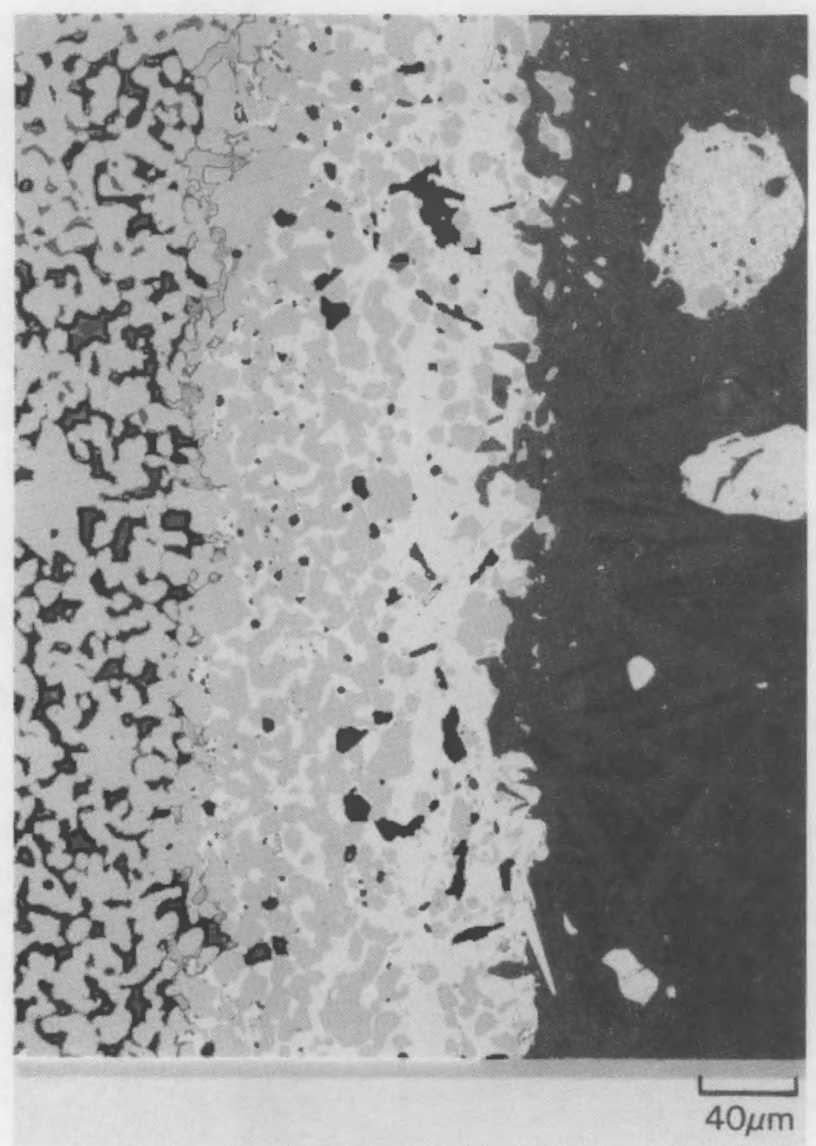

FIGURE 24. Higher Magnification of Reaction Area Shown in Figure 23. Phase at reaction interface between $\mathrm{TiB}_{2}-\mathrm{G}$ and $\mathrm{Al}$ may be $\mathrm{Al}_{4} \mathrm{C}_{3}$. 


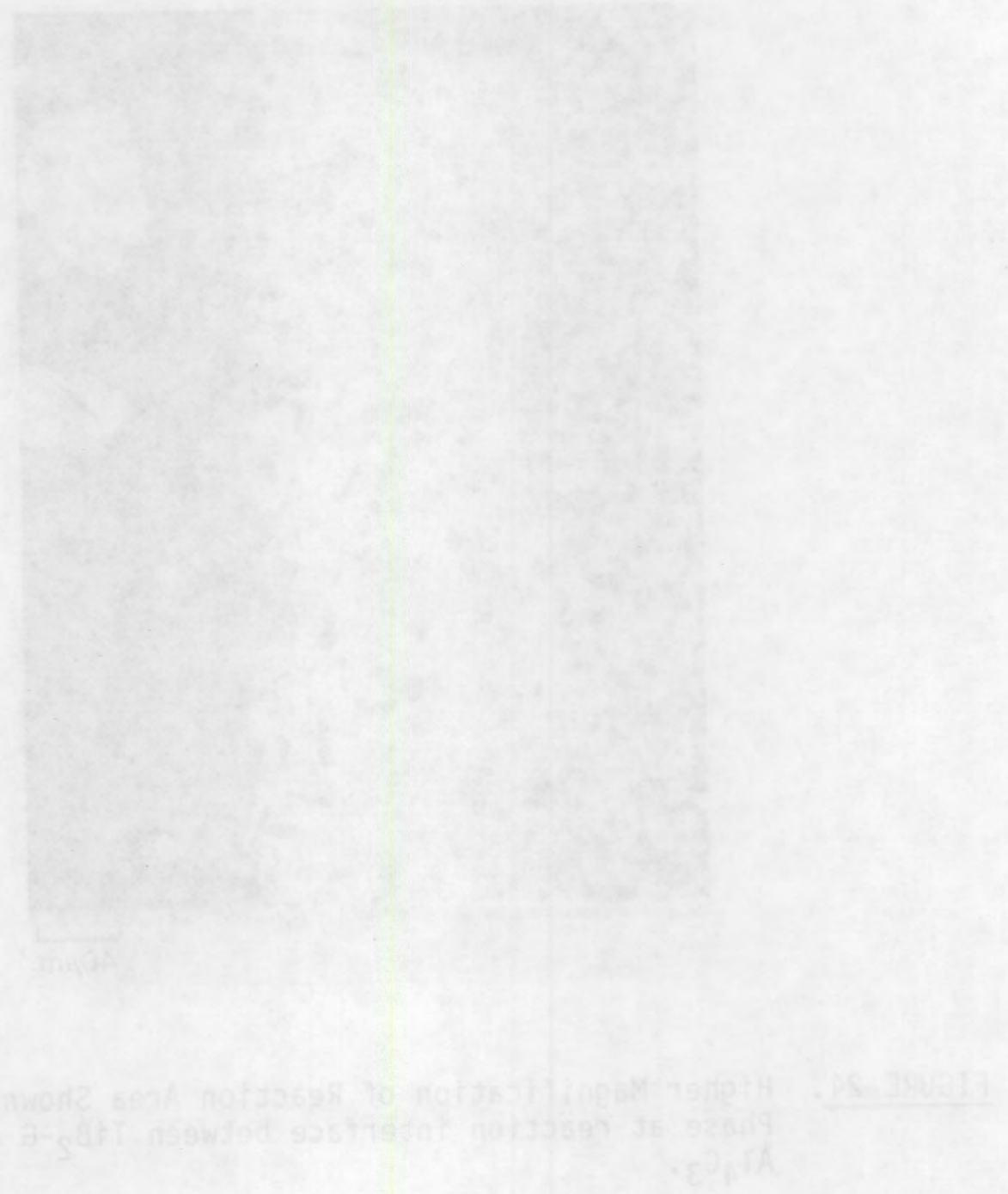




\section{REFERENCES}

Dewing, E. W. 1969. Trans. of the Metallurgical Society of AIME 245, pp. 2181-2184.

Dewing, E. W. 1974. "The Chemistry of Alumina Reduction Cell." Can. Metall. Q. 13(4):607-618.

Grjotheim, K., R. Naeuman, and H. A. Oye. 1977. Light Metals. pp. 233-242.

Hollingshead, E. A., and J. A. Brown. 1982. "Rate of Solution of Carbon in Molten Aluminum Under a Cryolite Melt." Light Metals, pp. 625-634.

Odegard, R., A. Sterten, and J. Thonstad. 1984. Paper presented at EUCHEM mecting, Denmark. 



\section{ACKNOWLEDGMENTS}

The contributions of the following people are gratefully acknowledged:

- M. J. McMonigle, U.S. Department of Energy, Office of Industrial Programs, for his support and encouragement.

- J. R. Divine, Pacific Northwest Laboratory (PNL), for project management efforts and assistance in planning experiments.

- P. H. Swift, PNL, for construction and operation of transference cells.

- L. S. Dake and S. C. Marschman, PNL, for x-ray photoelectron spectroscopy and Auger electron spectroscopy analyses.

- S. L. 0'Dell, PNL, secretarial support.

- S. K. Edler and G. P. O'Connor, PNL, editorial and publishing support. 

APPENDIX A

TRANSFERENCE CELL DATA 


\section{TRANSFERENCE CELL DATA}

TABLE A.1. Aluminum Carbide Content of Samples from Graphite
Cathode Test $(a)$

\begin{tabular}{|c|c|c|}
\hline Elapsed Time, $\mathrm{h}$ & $\mathrm{Al}_{4} \mathrm{C}_{3}$ Found, wt\% & Sample Location \\
\hline 2 & 0.038 & Composite of whole core sample \\
\hline 2.5 & 0.098 & Composite of whole core sample \\
\hline 3 & 0.057 & Composite of whole core sample \\
\hline 3.8 & 0.097 & Top portion of core \\
\hline 3.8 & 0.085 & Middle portion of core \\
\hline 3.8 & 0.097 & Bottom portion of core \\
\hline 4.75 & 0.092 & Top portion of core \\
\hline 4.75 & 0.102 & Middle portion of core \\
\hline 4.75 & 0.119 & 8ottom portion of core \\
\hline \multicolumn{3}{|c|}{ End of test (cold samples) } \\
\hline & 0.120 & From anode area \\
\hline & 0.137 & From cathode area \\
\hline & 0.45 & $\begin{array}{l}\text { From anode area with Al } \\
\text { needles included }\end{array}$ \\
\hline
\end{tabular}

(a) Initial mass of cryolite bath $=860 \mathrm{~g}$; current density $=3.0 \mathrm{~A} / \mathrm{cm}^{2}$. 
TABLE A.2. Results from Test EB-17(a)

$\begin{array}{ccc}\text { Electrolysis Time, } n & \frac{\mathrm{A}]_{4} \mathrm{C}_{3} \text { Found, } g}{0.0013} & \begin{array}{c}\text { Portion of } \\ \text { Sample Core Analyzed }\end{array} \\ 1.25 & 0.063 & \text { Middle } \\ 1.25 & 0.088 & \text { Top } \\ 2 & 0.043 & \text { Bottom } \\ 3 & 0.118 & \text { Composite } \\ 4 & 0.281 & \text { Composite } \\ 5 & 0.273 & \text { Composite } \\ 6 & 0.309 & \text { Composite } \\ 7 & 0.391 & \text { Composite }\end{array}$

(a) $T i B_{2}-G$, Type $B$, verticąl configuration; 779-g standagd bath; exposed area $=13.9 \mathrm{~cm}^{2}$; current density $=1.04 \mathrm{~A} / \mathrm{cm}^{2}$. These data are shown graphically in Figure 3 of the main text. 
TABLE A.3. Results from Test EB-19(a)

\section{Electrolysis Time}

15 min

37 min

$1 \mathrm{~h}$

$2 \mathrm{~h}$

$3 \mathrm{~h}$

$4 \mathrm{~h}$

$5 \mathrm{~h}$

$6 \mathrm{~h}$
$\mathrm{Al}_{4} \mathrm{C}_{3}$ Found, $\mathrm{g}$

0.011

0.0053

0.049

0.051

$0.278^{(b)}$

0.554

1.18

1.37

(a) TiB $-G$, Type $B$, horizontal configuration; $1069 \rightarrow 9$ standard bath; exposed area $\overline{\overline{2}}$ $2.3 \mathrm{~cm}^{2}$; current density $=1.3 \mathrm{~A} / \mathrm{cm}^{2}$; composite samples. These data are shown graphically in Figure 5 of the main text.

(b) The rate of $\mathrm{Al}_{4} \mathrm{C}_{3}$ formation after the 2-h sample increased dramatically. The alumina test crucible probably cracked sometime after the 2-h sample, which exposed cell contents to the graphite outer cell. 
TABLE A.4. Results from Test EB-23(a)

\begin{tabular}{cc} 
Electrolysis Time, $h$ & $\frac{A_{1}{ }_{4} C_{3} \text { Found, } g}{0.068}$ \\
\hline 1 & 0.082 \\
3 & 0.126 \\
4 & 0.118 \\
5 & 0.180 \\
6 & 0.173
\end{tabular}

(a) $\mathrm{TiB}_{2}-\mathrm{G}$, Type $\mathrm{A}$, horizontal configuration; $223-\mathrm{g}$ standard bath; exposed area $=$
$2.3 \mathrm{~cm}^{2}$; current density $=1.3 \mathrm{~A} / \mathrm{cm}^{2}$; composite samples. These data are shown graphically in Figure A.1.

TABLE A.5. Results from Test EB-24(a)

\section{Electrolysis Time}

35 min

$1.5 \mathrm{~h}$

$2.5 \mathrm{~h}$

$3.75 \mathrm{~h}$

$4 \mathrm{~h} 40 \mathrm{~min}$

$6 \mathrm{~h} 40 \mathrm{~min}$
$\mathrm{Al}_{4} \mathrm{C}_{3}$ Found, $\mathrm{g}$

0.006

0.163

0.224

0.206

0.264

0.232

(a) $\mathrm{TiB}_{2}-\mathrm{G}$, Type $\mathrm{B}$, vertical configuration; $249-g$ standard bath; exposed area = $9.8 \mathrm{~cm}^{2}$; current density $=0.80 \mathrm{~A} / \mathrm{cm}^{2}$; composite samples. These data are shown graphically in Figure A.2. 


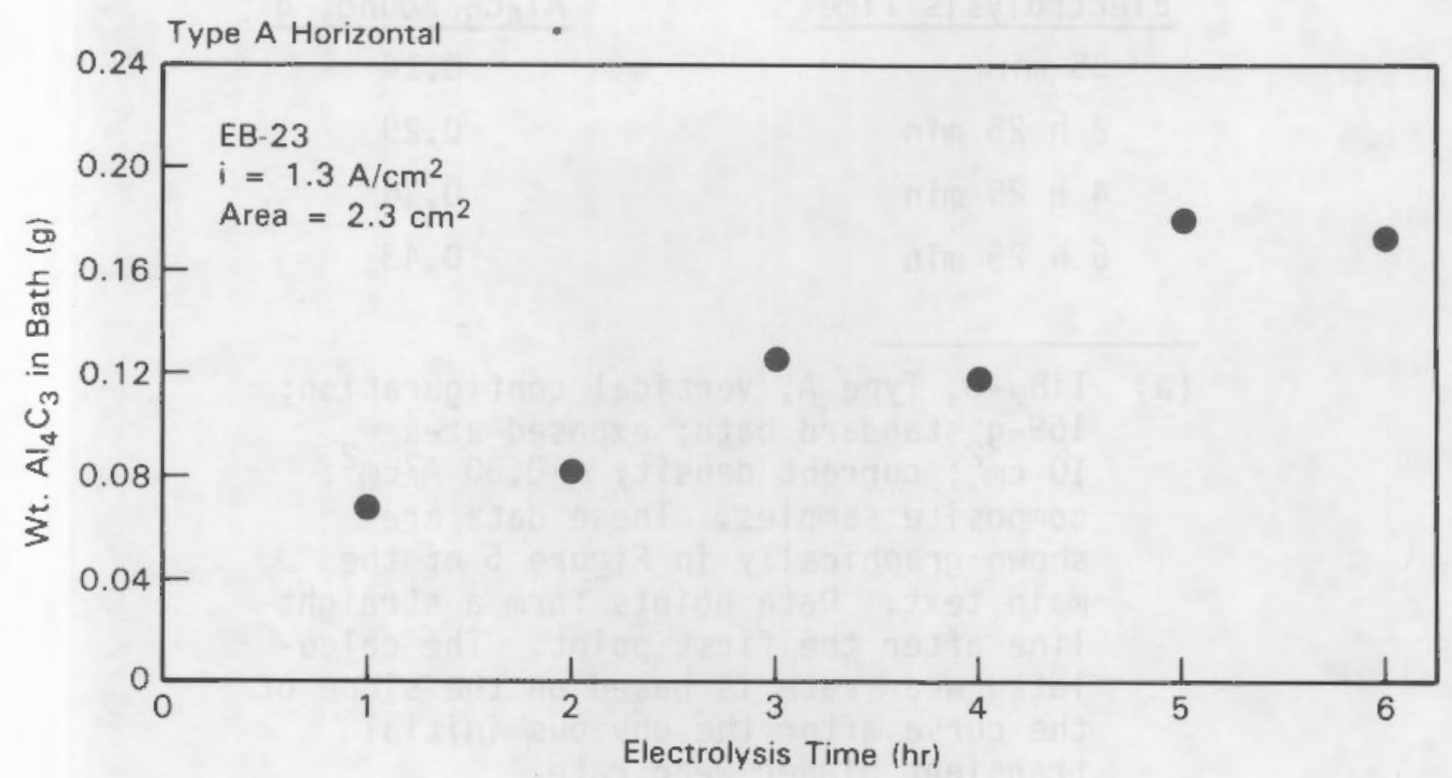

FIGURE A.1. $\mathrm{Al}_{4} \mathrm{C}_{3}$ Content of Bath as a Function of Electrolysis Time for Test EB-23

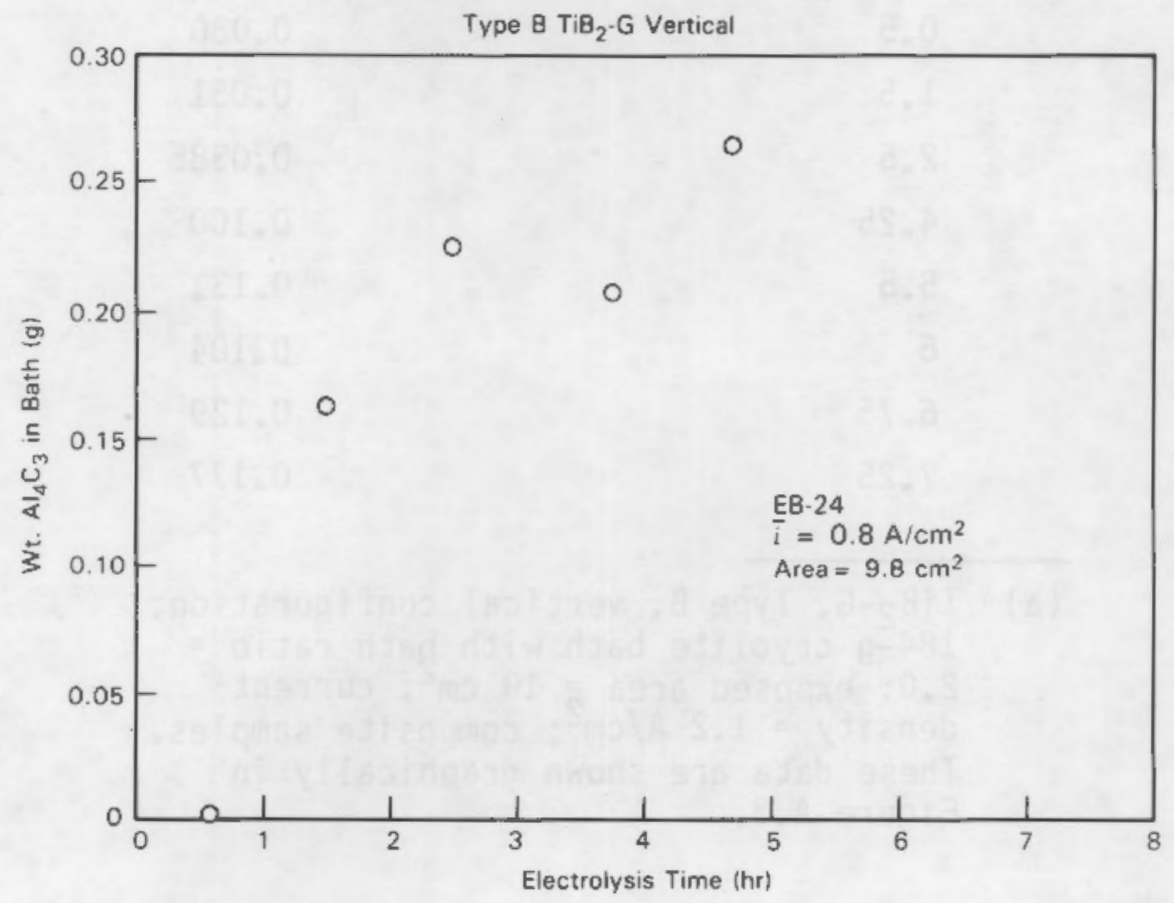

FIGURE A.2. $\mathrm{Al}_{4} \mathrm{C}_{3}$ Content of Bath as a Function of Electrolysis Time for Test EB-24 
TABLE A.6. Results from Test EB-25(a)

\section{Electrolys is Time}

35 min

2 h $25 \min$

$4 \mathrm{~h} 25 \mathrm{~min}$

$6 \mathrm{~h} 25 \min$
$\mathrm{Al}_{4} \mathrm{C}_{3}$ Found, $\mathrm{g}$

0.14

0.29

0.36

0.43

(a) $\mathrm{TiB}_{2}-\mathrm{G}$, Type $\mathrm{A}$, vertical configuration; $169-\mathrm{g}$ standard bath; exposed area $=$ $10 \mathrm{~cm}^{2}$; current density $=0.80 \mathrm{~A} / \mathrm{cm}^{2}$; composite samples. These data are shown graphically in Figure 5 of the main text. Data points form a straight line after the first point. The calculated wear rate is based on the slope of the curve after the obvious initial transient higher wear rate.

TABLE A.7. Results from Test $E B-27$ (a)

Electrolysis Time, $h$

0.5

1.5

2.5

4.25

5.5

6

6.75

7.25
$\mathrm{Al}_{4} \mathrm{C}_{3}$ Found $(\mathrm{g})$

0.080

0.051

0.0385

0.100

0.131

0.104

0.129

0.177

(a) $\mathrm{TiB}_{2}-\mathrm{G}$, Type $\mathrm{B}$, vertical configuration; 184-g cryolite bath with bath ratio = 2.0; exposed area $\equiv 10 \mathrm{~cm}^{2}$; current density $=1.2 \mathrm{~A} / \mathrm{cm}^{2}$; composite samples. These data are shown graphically in Figure A.3. 


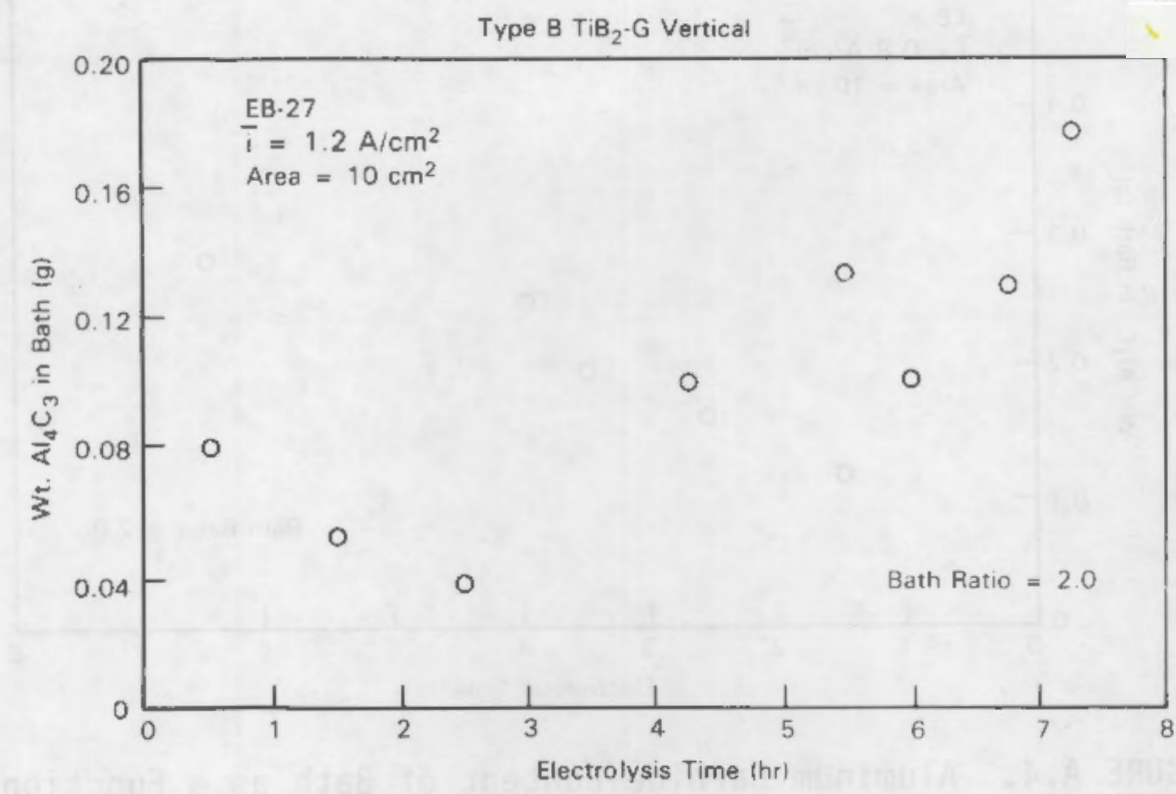

FIGURE A.3. Aluminum Carbide Content of Bath as a Function of Electrolysis Time for Test EB-27

TABLE A.8. Results from Test $E B-30(a)$

Electrolysis Time

$1.5 \mathrm{~h}$

2 h 35 min

$3.5 \mathrm{~h}$

$4 \mathrm{~h}$

$6.5 \mathrm{~h}$
$\mathrm{Al}_{4} \mathrm{C}_{3}$ Found $(\mathrm{g})$

0.118

0.162

0.199

0.250

0.282

(a) $\mathrm{TiB}_{2}-\mathrm{G}$, Type $\mathrm{A}$, vertical configuration; $169-\mathrm{g}$ cryolite bath with bath ratio = 2.0; exposed area $=10 \mathrm{~cm}^{2}$; current density $=0.8 \mathrm{~A} / \mathrm{cm}^{2}$; composite samples. These data are shown graphically in Figure A.4. 
Type A $\mathrm{TiB}_{2}-\mathrm{G}$ Vertical

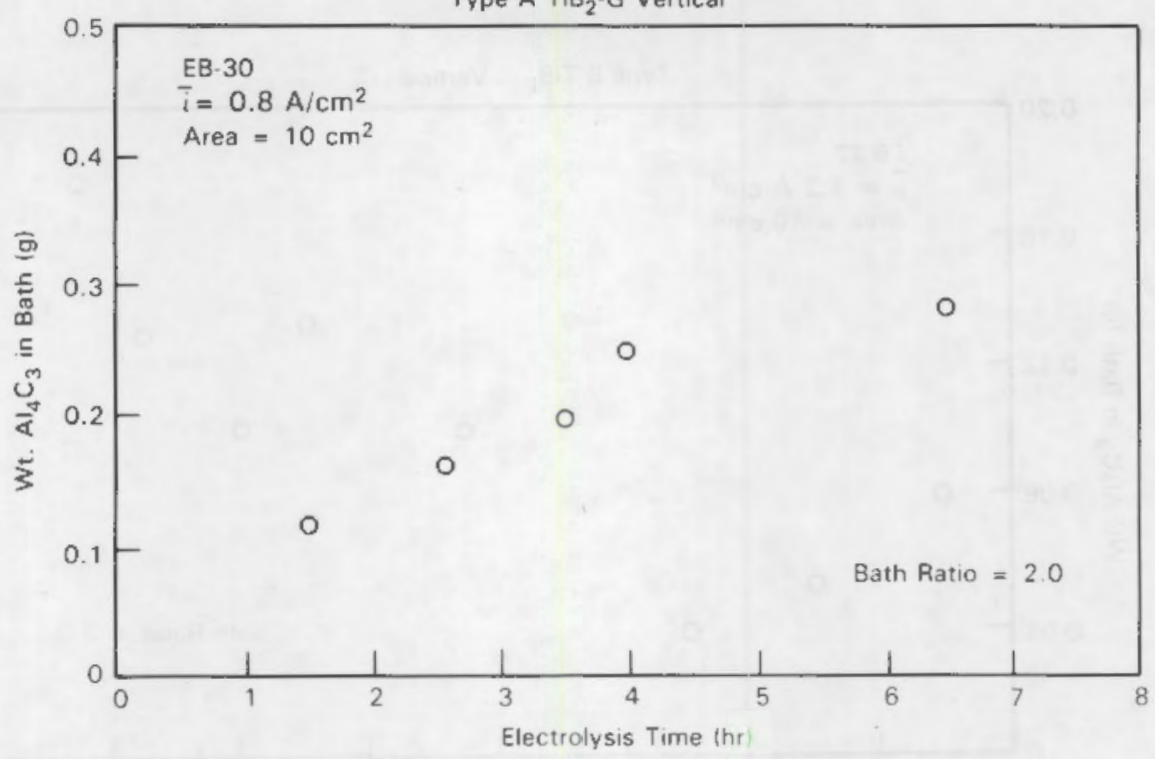

FIGURE A.4. Aluminum Carbide Content of Bath as a Function of Electrolysis Time for Test EB-30

TABLE A.9. Results from Test EB-29(a)

\begin{tabular}{ll} 
Electrolysis Time & $\mathrm{Al}_{4} \mathrm{C}_{3}$ Found $(\mathrm{g})$ \\
\hline 25 min & 0.0005 \\
55 min & 0.046 \\
1 h $55 \mathrm{~min}$ & 0.0787 \\
$3 \mathrm{~h} 35 \mathrm{~min}$ & 0.0673 \\
$4 \mathrm{~h}$ & 0.0715 \\
$4 \mathrm{~h} 55 \mathrm{~min}$ & 0.0684 \\
$5 \mathrm{~h} 55 \mathrm{~min}$ & 0.104
\end{tabular}

(a) $\mathrm{TiB}_{2}-\mathrm{G}$, Type $\mathrm{B}$, horizontal configuration; $174 \mathrm{~g}$ standard bath; exposed area $=2.3 \mathrm{~cm}^{2}$; current density $=$ $0.87 \mathrm{~A} / \mathrm{cm}^{2}$; composite samples. These data are shown graphically in Figure A.5. 


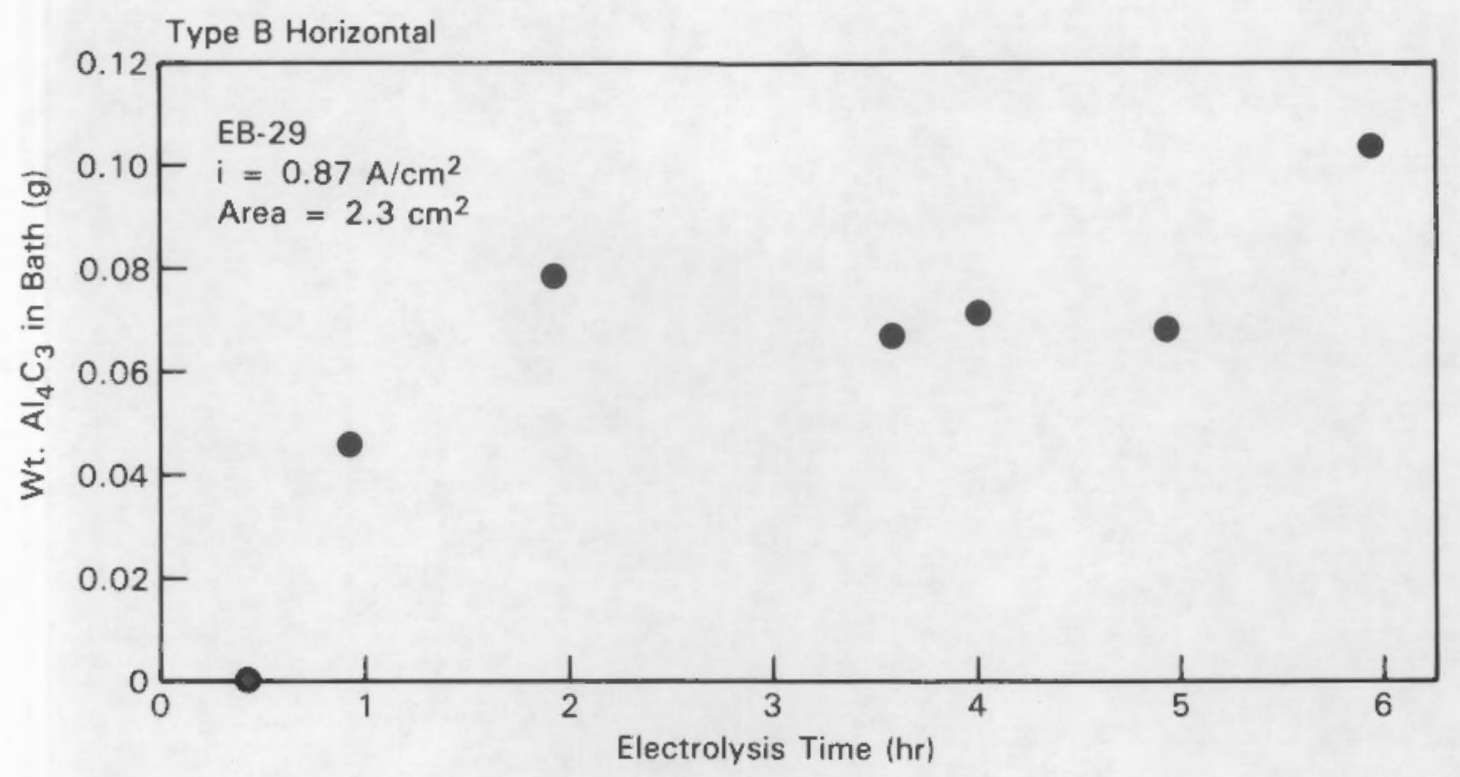

FIGURE A.5. Aluminum Carbide Content of Bath as a Function of Electrolysis Time for Test EB-29 

APPENOIX B

$\mathrm{Al}_{4} \mathrm{C}_{3}$ ANALYSIS 


\section{APPENDIX B}

\section{$\mathrm{Al}_{4} \mathrm{C}_{3}$ ANALYSIS}

\section{BACKGROUND}

$\mathrm{Al}_{4} \mathrm{C}_{3}$ reacts with sodium hydroxide to produce methane as follows: $\mathrm{Al}_{4} \mathrm{C}_{3}+4 \mathrm{NaOH}+4 \mathrm{H}_{2} \mathrm{O}+4 \mathrm{NaAlO}_{2}+\mathrm{CH}_{4}$. The $\mathrm{CH}_{4}$ from this reaction was analyzed with a Varian Aerograph gas chromatograph (GC) with helium ionization detectors and a 6-ft 5-A molecular sieve column. This GC is operated with a vacuum system to minimize introduction of air into the gas sampling system.

Equipment

1.

2.

3.

4.

5.

6.

7.

8.
Reaction Vessel - 200-mL volume with a port for addition of $\mathrm{NaOH}$, vacuum tight, and volume calibrated.

Vacuum System and Associated Gas Traps - volumes receiving gas from the sample must be calibrated.

Manometers - for pressure data in torr, MKS Baratron-1000 torr + 10 torr manometers.

Gas Chromatograph with Sampling Valve $-0.25 \mathrm{~mL}$ and $5 \mathrm{~mL}$ Varian Aerograph with helium ionization detectors and 6-ft 5-A molecular sieve column (also a 10-ft Poropak Q column).

Sand Bath with Temperature Controller - to immerse and heat reaction vessel plus thermocouples to read temperatures in the sand bath. Helium Glove Box Dry Ice, Trap, and Dewar - removal of water vapor. Helium Tank and Regulator 
Chemicals

1.

2.

3.

4.

5.

Procedure

1.

2.

3.

4.

5.

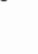

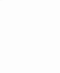

$\mathrm{Al}_{4} \mathrm{C}_{3}$ aluminum carbide, $\mathrm{Aldrich}$, Lot $\# 3311 \mathrm{BJ}$ was used for calibration.

Greenland cryolite.

Aluminum.

Hall cell bath mixture: $3000 \mathrm{~g}$ Greenland cryolite, $480 \mathrm{~g}$ $\mathrm{AlF}_{3}, 480 \mathrm{~g} \mathrm{Al}_{2} \mathrm{O}_{3}$, and $165 \mathrm{c} \mathrm{CaF}_{2}$ blended for $48 \mathrm{~h}$ in a $\checkmark$-blender.

Reagent-grade $2 \underline{\mathrm{M}} \mathrm{NaOH}$.

A weighed sample $(\sim 50 \mathrm{mg})$ is placed in the reaction vessel, sealed, and evacuated of gas.

About $10 \mathrm{~mL}$ of $2 \mathrm{M} \mathrm{NaOH}$ is introduced to sample in reaction vessel, the $10 \mathrm{~mL}$ water is added to rinse the valve.

Reaction vessel is immersed into a sand bath and heated overnight to $\sim 100^{\circ} \mathrm{C}$ so that the reaction is complete. The reaction vessel is removed from the sand bath and temperature equilibrated back to room temperature. The trap volume is well evacuated and filled with helium, which is used to backfill (a) the reaction vessel. A reduced pressure ( $20 \mathrm{~mL}$ at 150 torr) of helium was used for the cryolite bath samples for backfilling the vessels. If the sample was aluminum, atmospheric pressure of helium was required for backfilling to overcome the hydrogen pressure.

(a) Backfilling is necessary to clear the valves from the vessel to the trap to insure equilibration of gas pressures bet'ween trap and vessel. 
6.

7.

8.

9.

10.
The trap is re-evacuated and isolated, then the reaction vessel is expanded to the trap and pressure equilibrated. The gas in the trap is then isolated from the reaction vessel (hence, a known portion is taken).

The trap is immersed in dry ice to remove water vapor. The gas in the trap is expanded into the volume calibrated portions of the vacuum system, then to the Toepler Pump, which is used to mix and concentrate the gas in volume calibrated parts of the vacuum system. If $A l$ metal is analyzed for $\mathrm{Al}_{4} \mathrm{C}_{3}$, the pressures from the vessel will be too high for the Toepler pump mixing and may be analyzed directly.

Gas is analyzed via the GC to give the proportion of the total gas that is methane. The GC is calibrated with various pressures of a standardized gas mixture. Calculations are made using the ideal gas law:

$$
n=\frac{P V}{R T} \text { moles total gas }
$$

and the portion of the gas that is $\mathrm{CH}_{4}$

$$
\frac{\%}{100} \text { or ppm } \times 10^{-6} \times \text { moles total gas }(n)
$$

Once the moles of $\mathrm{CH}_{4}$ is determined, $\mathrm{Al}_{4} \mathrm{C}_{3}$ content is back calculated from the chemical equation. 
TABLE B.1. Reproducibility of $\mathrm{Al}_{4} \mathrm{C}_{3}$ Standard Mixtures (a-c)

\begin{tabular}{|c|c|c|c|c|}
\hline A $A_{A} C_{3}, w t \%$ & $\begin{array}{c}\text { Analysis } \\
\text { Date } \\
\end{array}$ & $\begin{array}{c}\mathrm{Al}_{4} \mathrm{C}_{3} \text { by } \\
\text { Analysis, wt\% } \\
\end{array}$ & $\begin{array}{c}\text { Reproducibility, } \\
\quad \text { Average } \pm S D \\
\end{array}$ & Comments \\
\hline $\begin{array}{l}1.0334 \\
\text { in cryolite }\end{array}$ & $\begin{array}{r}8-14-85 \\
8-16-85 \\
8-16-85 \\
8-20-85 \\
8-20-85 \\
12-31-85 \\
1-03-86 \\
1-10-86 \\
2-05-86 \\
2-05-86\end{array}$ & $\begin{array}{l}0.799 \\
0.845 \\
0.815 \\
0.819 \\
0.805 \\
0.922 \\
0.814 \\
0.774 \\
0.867 \\
0.654\end{array}$ & $0.811 \pm 8.5 \%$ & \\
\hline \multirow[t]{3}{*}{$\begin{array}{l}0.10337 \\
\text { in cryolite }\end{array}$} & $1-25-86$ & 0.0472 & set for a week & Reaction vessel \\
\hline & $1-25-86$ & 0.0717 & set for a week & Reaction vessel \\
\hline & $\begin{array}{l}1-27-86 \\
1-30-86 \\
2-03-86 \\
2-06-86 \\
2-06-86\end{array}$ & $\begin{array}{l}0.0988 \\
0.0534 \\
0.0586 \\
0.0519 \\
0.0530\end{array}$ & $0.0621 \pm 28.9 \%$ & $\begin{array}{l}\text { Mixed } 1.0334 \% \\
\text { mixture with } \\
\text { cryolite. Did } \\
\text { not mix well on } \\
\text { roller mill. }\end{array}$ \\
\hline $\begin{array}{l}0.01229 \\
\text { in cryolite }\end{array}$ & $\begin{array}{l}1-25-86 \\
1-25-86 \\
1-27-86 \\
2-03-86\end{array}$ & $\begin{array}{l}0.0088 \\
0.0114 \\
0.0105 \\
0.0082\end{array}$ & $\begin{array}{l}0.00972 \pm 15.2 \% \\
\text { roller mill. }\end{array}$ & $\begin{array}{l}\text { Mixed } 1.0334 \% \\
\text { mixture with } \\
\text { cryolite. } \\
\text { Mixed well on }\end{array}$ \\
\hline $\begin{array}{l}0.9995 \text { in } \\
\text { aluminum }\end{array}$ & $\begin{array}{l}8-01-85 \\
8-01-85\end{array}$ & $\begin{array}{l}0.666 \\
0.681\end{array}$ & $\begin{array}{l}0.00674 \pm 1.6 \% \\
\text { short reaction } \\
\text { time. }\end{array}$ & $\begin{array}{l}\text { Analys is may be } \\
\text { low due to }\end{array}$ \\
\hline $100 \% \mathrm{Al}_{4} \mathrm{C}_{3}$ & $\begin{array}{l}9-29-85 \\
7-29-85 \\
7-30-85 \\
7-30-85\end{array}$ & $\begin{array}{l}81.0 \\
69.4 \\
70.1 \\
70.7\end{array}$ & $72.8 \% \pm 7.5 \%$ & \\
\hline
\end{tabular}

(a) The purest $\mathrm{Al}_{4} \mathrm{C}_{3}$ material available was Aldrich, Lot $3311 \mathrm{BJ}$, which was estimated to be $80 \%$ to $85 \% \mathrm{Al}_{4} \mathrm{C}_{3}$ by $x$-ray diffraction.

(b) Stated weight percents are uncorrected for $\mathrm{Al}_{4} \mathrm{C}_{3}$ purity.

(c) Standards are less reproducible than samples as they are particulate mixtures rather than solution mixtures. 
TABLE B.2. Reproducibility of Hall Cell Bath Samples

\begin{tabular}{|c|c|c|c|c|}
\hline Sample ID & $\begin{array}{c}\text { Analys is } \\
\text { Date }\end{array}$ & $\begin{array}{c}\mathrm{Al}_{4} \mathrm{C}_{3} \text { by } \\
\text { Analysis, wt\% }\end{array}$ & $\begin{array}{l}\text { Reproducibility, } \\
\text { Average } \pm S D \\
\end{array}$ & Comments \\
\hline $\begin{array}{l}E B-1 T \\
E B-1 T\end{array}$ & $\begin{array}{l}9-05-85 \\
9-09-85\end{array}$ & $\begin{array}{l}0.300 \\
0.332\end{array}$ & $0.316 \pm 7.2 \%$ & \\
\hline $\begin{array}{l}E B-1 B \\
E B-1 B\end{array}$ & $\begin{array}{l}9-05-85 \\
9-09-85\end{array}$ & $\begin{array}{l}0.169 \\
0.166\end{array}$ & $0.168 \pm 1.3 \%$ & \\
\hline $\begin{array}{l}\text { EB-10, } \# 3 \\
\text { Inside } \\
\text { Middle }\end{array}$ & $\begin{array}{c}1-13-86 \\
1-15-86 \\
--\end{array}$ & $\begin{array}{c}0.470 \\
0.398 \\
--\end{array}$ & $0.434 \pm 11.7 \%$ & \\
\hline $\begin{array}{l}\text { EB-10, } \$ 3 \\
\text { Inside } \\
\text { Bottom }\end{array}$ & $\begin{array}{l}1-14-86 \\
1-14-86 \\
1-13-86\end{array}$ & $\begin{array}{l}0.351 \\
0.342 \\
0.527\end{array}$ & $0.407 \pm 25.6 \%$ & \\
\hline $\begin{array}{l}E B-10, \# 4 \\
E B-10, \# 4\end{array}$ & $\begin{array}{l}1-16-86 \\
1-16-86\end{array}$ & $\begin{array}{l}0.574 \\
0.580\end{array}$ & $0.577 \pm 0.7 \%$ & \\
\hline $\begin{array}{l}\text { EB-11, \#2 } \\
\text { Inside } \\
\text { Middle }\end{array}$ & $\begin{array}{c}1-29-86 \\
1-31-86 \\
--\end{array}$ & $\begin{array}{c}0.0120 \\
0.0122 \\
--\end{array}$ & & \\
\hline $\begin{array}{l}\text { EB-11, } \$ 3 \\
\text { Inside } \\
\text { Middle }\end{array}$ & $\begin{array}{c}1-30-86 \\
1-31-86 \\
--\end{array}$ & $\begin{array}{c}0.0083 \\
0.0084 \\
--\end{array}$ & $0.0084 \pm 0.8 \%$ & \\
\hline
\end{tabular}

TABLE B.3. Background Levels of $\mathrm{Al}_{4} \mathrm{C}_{3}$

\begin{tabular}{|c|c|c|c|c|}
\hline $\begin{array}{r}\text { Hall Cell } \\
\text { Component } \\
\end{array}$ & $\begin{array}{l}\text { Analys is } \\
\text { Date } \\
\end{array}$ & $\begin{array}{c}\mathrm{Al}_{4} \mathrm{C}_{3} \text { by } \\
\text { Analysis, wt\% } \\
\end{array}$ & $\begin{array}{l}\text { Average } \\
\mathrm{Al}_{4} \mathrm{C}_{3} \\
\end{array}$ & Comments \\
\hline Cryolite & $\begin{array}{l}8-13-85 \\
8-20-85 \\
8-20-85 \\
8-26-85 \\
8-26-85 \\
8-30-86 \\
8-30-86\end{array}$ & $\begin{array}{r}0.0013 \\
D .0017 \\
0.0002 \\
<0.0002 \\
<0.0002 \\
<0.0002 \\
<0.0002\end{array}$ & $\sim 0.0002$ & $\begin{array}{l}0.0017 \text { - omitted } \\
\text { from average, } \\
\text { considered a } \\
\text { flyer }\end{array}$ \\
\hline $\begin{array}{l}\text { Cryolite bath } \\
\text { mixture }\end{array}$ & $3-05-86$ & 0.0002 & & \\
\hline $\begin{array}{l}\text { A1 ribbon } \\
\text { Al button }\end{array}$ & $\begin{array}{l}3-05-86 \\
3-05-86\end{array}$ & $\begin{array}{l}0.0018 \\
0.0023\end{array}$ & & \\
\hline
\end{tabular}





\section{APPENDIX C}

THERMAL STABILITY OF ALUMINUM CARBIDE 
THERMAL STABILITY OF ALUMINUM CARBIDE

Thermogravimetric analysis (TGA) and mass spectroscopy (MS) were used to define the thermal stability limit and degradation products of $\mathrm{Al}_{4} \mathrm{C}_{3}$. Nitrogen, argon, and dry air atmospheres were used.

In both $\mathrm{N}_{2}$ and argon atmospheres, no significant weight change $(<0.1 \%)$ of neat $\mathrm{Al}_{4} \mathrm{C}_{3}$ is observed up to $1100^{\circ} \mathrm{C}$. Thus, $\mathrm{Al}_{4} \mathrm{C}_{3}$ is stable in nonoxidizing atmosphere up to at least $1100^{\circ} \mathrm{C}$.

In dry air, $\mathrm{Al}_{4} \mathrm{C}_{3}$ sample weights began increasing at about $650^{\circ} \mathrm{C}$. The rate of decomposition appears to increase as temperatures increase up to about $1050^{\circ} \mathrm{C}$. Based on the assumed decomposition reaction:

$$
\mathrm{Al}_{4} \mathrm{C}_{3}+6 \mathrm{O}_{2}+2 \mathrm{Al}_{2} \mathrm{O}_{3}+3 \mathrm{CO}_{2}
$$

approximately $50 \%$ of the original $\mathrm{Al}_{4} \mathrm{C}_{3}$ decomposed during the test. Total time at temperature above $650^{\circ} \mathrm{C}$ was $21 / 2 \mathrm{~h}$. Mass spectra taken at $30-\mathrm{s}$ intervals during this experiment showed two obvious $\mathrm{CO}_{2}$ release peaks--one at approximately $700^{\circ} \mathrm{C}$ and the other at approximately $1000^{\circ} \mathrm{C}$. The higher temperature $\mathrm{CO}_{2}$ release peak represented approximately twice as much $\mathrm{CO}_{2}$ as the $700^{\circ} \mathrm{C}$ peak. $\mathrm{A}$ completely satisfactory explanation for this observed two-step $\mathrm{CO}_{2}$ release is not available.

The main point here is that $\mathrm{Al}_{4} \mathrm{C}_{3}$ readily decomposes in air (oxygen) at Hall-Heroult cell operating temperatures. Dissolved and solvated carbide in cryolite is probably even more susceptible to attack by oxidants. The fact that rigorous exclusion of oxygen and water vapor was necessary to prevent loss of carbide in transference cell tests is consistent with the results obtained from TGA-MS. 

APPENDIX D

ANALYSIS OF A TiB 2 -G CATHODE USING XPS AND AES 
APPENDIX D

ANALYSIS OF A TiB $2-G$ CATHODE USING XPS AND AES

A cathode was fabricated from Type A provided by Great Lakes Carbon. The exact composition of the $\mathrm{TiB}_{2}-\mathrm{G}$ was not provided by Great Lakes. The cathode was fabricated for use in an experimental Hall-Heroult cell to determine the behavior of this material under polarized conditions. A molydenum rod was used as the cathode lead, and the method of connecting the rod to the $\mathrm{SiB}_{2}-\mathrm{G}$ was also tested in this experiment. The cathode measured 2 in. long, 1 in. wide, and $0.29 \mathrm{in}$. thick. The cell was operated at a cathode current density of $1.1 \mathrm{~A} / \mathrm{cm}^{2}$ in a electrolyte solution having a bath ratio of 1.07 . The cathode was placed in the cell in a vertical position. The experiment was run for $6 \mathrm{~h}$ and the bath was maintained at alumina saturation.

The cathode was removed from the cell at the completion of the experiment. The surface of the cathode had a thin green layer of an unknown material in severai places. These areas were suspected to be an aluminum carbide phase, which would indicate degradation of the cathode material. The cathode sample was analyzed using $x$-ray photoelectron spectroscopy (XPS) and Auger electron spectroscopy (AES) to determine the composition of the light green areas. The XPS and AES techniques can provide elemental identification within a surface layer approximately $3 \mathrm{~nm}$ thick. The area analyzed with XPS was approximately $4 \mathrm{~mm}$ in diameter. The optimum spatial resolution of the AES instrumentation used for this work was $0.8 \mu \mathrm{m}$.

The AES technique uses a primary electron beam (2 to $10 \mathrm{KeV}$ ) that is focused onto the solid surface, creating a core electron vacancy. Relaxation of the electronic structure involving two other electron energy levels leads to emission of Auger electrons. The energies and intensities of the emitted Auger electrons are measured. Elements are identified through their characteristic spectra. The intensities of specific Auger electron spectral peaks can be used to semiquantitively determine concentrations on the surface. 
The XPS technique impinges $x$-ray photons (in this case, Mg $K$ ) on the solid surface to be analyzed, and causes photoelectrons to be emitted. The energy and intensity of these photoelectrons are then carefully analyzed. Elements on the sample surface are identified through their characteristic spectra. The relative intensities of the peaks allow semiquantitative concentration determinations. Minor shifts in the energies of the photoelectron spectral peaks are used to obtain much of the chemical valence state information.

The accuracy of the XPS and AES concentration calculations are not trivial to determine without standards and is currently seing disputed in the literature. Typical reported accuracies for the sort of calculation done here are $\pm 30 \%$. Better accuracies can only be assured with the use in known concentration standards with chemical matrices similar to that of the specific samples being examined. The precision of the measurements (i.e., the reproducibility) is considerably better, with values of $\pm 10 \%$ typical for samples of this type. Detection limits are also not trivial to calculaze since they are determined by intrinsic elemental sensitivity factors, instrument characteristics, signal-tonoise ratios in the specific spectral region, and will also be influenced by the sample itself. Thus, the detection limits which vary from element to element, may vary from sample to sample, and even from one spectra to the next on a given sample. Typical detection limits range a few tenths of a percent to a few percent.

Sputter-etching consists of hitting the sample with a beam of argon ions. The ion beam has sufficient energy to remove layers of atoms from the sample surface. AES and/or XPS data can then be taken, and the elemental concentrations can be monitored as a function of depth. In this manner, depth profile information may be obtained.

\section{EXPERIMENTAL}

The sample had been cut to the appropriate size for analysis using an oilcooled saw. Sequential ultra-sonic rinses in acetone and methanol were required to remove the oil from the sample. The sample surface was very porous, and serious outgassing occurred when the sample was put into the 
analys is chamber. Therefore, the sample had to be pumped on overnight before analyzing so that acceptable pressures could be maintained in the high vacuum system.

All spectra were obtained using a Physical Electronics 560 spectrometer equipped with a double-pass cylindrical mirror analyzer. For the XPS data, a 15-KeV 300-W MgK x-ray source (1253.6 eV) was used. The spectrometer was calibrated so that the $\mathrm{Cu} 2 \mathrm{p}_{3 / 2}$ line appeared at $932.4 \mathrm{eV}$ and the Au $4 \mathrm{f}_{7 / 2}$ line at $83.8 \mathrm{eV}$. Charge referencing was made to the adventitious $C$ is 1 ine at $284.6 \mathrm{eV}$. A pass energy of $100 \mathrm{eV}$ was used for the survey data. The AES data was taken using a $5-\mathrm{KeV}$ primary electron beam and beam currents of 0.03 to $0.05 \mathrm{~A}$.

RESULTS AND DISCUSSION

Table D.I shows the results of the XPS elemental analys is both on and off the green area. An ND entry indicates that the elements was not detected. A number of parenthesis means that while a peak was found in the proper location for that element, the magnitude of the peak was not much above the background level (these values provide a rough indication of the detection limits for that element). The symbol "Tr" indicates that a trace amount of that element was observed.

It was difficult to determine the significance of the composition differences seen in the two areas since it appeared that components from the melt were present in large quantities in both areas. There appeared to be slight evidence from the Auger data that some of the $C$ found in the green might be in

TABLE D.1. XPS Compositional Analys is for $\mathrm{TiB}_{2}-\mathrm{G}$ Cathode Sample

\begin{tabular}{|c|c|c|c|c|c|c|c|c|c|c|c|c|c|}
\hline & & & & & elati & $\mathrm{Cor}$ & positi & $n, a$ & $t . \%$ & & & & \\
\hline Location & $\overline{\mathrm{C}}$ & 0 & $\mathrm{Na}$ & Ca & Ti & $F$ & $N$ & Al & Si & $S$ & CT & $B$ & {$[i$} \\
\hline $\begin{array}{l}\text { Green } \\
\text { Area }\end{array}$ & 25 & 34 & 15 & $(0.5)$ & $(0.2)$ & 7.7 & ND & 14 & 0.5 & 0.4 & 0.8 & 1.7 & $\mathrm{Tr}$ \\
\hline $\begin{array}{l}\text { Off } \\
\text { Green }\end{array}$ & 15 & 41 & 8.8 & $(0.5)$ & $(0.2)$ & 10 & $(0.5)$ & 20 & 0.7 & 0.4 & 0.4 & 2.2 & $\mathrm{Tr}$ \\
\hline
\end{tabular}


the form of a carbide, but it was difficult to positively identify due to the large graphite or hydrocarbon signal. It was felt that by sputter-etching a better determination of the composition of the green area might be possible if the melt layer could be removed.

Most of the carbon was removed both on and off the green area after approximately 100 Angstroms of material had been removed, and what carbon remained appeared to be graphite or hydrocarbon. Therefore, it does not appear that the green area contained significant amounts of aluminum carbide. Furthermore, the aluminum data was consistent with an oxide form in all spectra, both on and off the green area. After approximately 300 Angstroms of sputtering, the major difference on and off the green areas was that relatively more $\mathrm{F}$ and $\mathrm{Na}$, and less aluminum oxide was seen away from the green area. The green appears to consist of "cleaner" aluminum oxide and is free from melt components. This is consistent with the observation that the green area appears visually to be located beneath the surface arust deposited from the melt onto the cathode.

The ion beam was focused so that a small arez within the green region could be rapidly sputtered. After about 1500 Angstroms of material was removed, the surface consisted primarily of aluminum oxide, with very small amounts of carbon, fluorine, and sodium remaining. After about 2500 \& (total) was removed, more fluorine was visible on the surface, and some silicon was evident. After visual inspection of the sample, it was determined that the green layer had been sputtered through.

\section{CONCLUSIONS}

The results of the study that aluminum carbide was not present on the surface of the cathode material. The composition of the green layer of interest in indicated in Table D.1. It should be noted that these values are qualitative as calibration against standards was not possible. 
DISTR IBUTION

No. of

Copies

\section{OFFSITE}

30 DOE Technical Information Center

T. J. Gross

U.S. Department of Energy

Office of Industrial Programs

Forrestal Building

Washington, DC 20585

M. J. McMonigle

U.S. Department of Energy

Office of Industrial Programs

Forrestal Building

Washington, DC 20585

R. L. Sheneman

U.S. Department of Energy

Office of Industrial Programs

Forrestal Building

Washington, DC 20585

W. B. Williams

U.S. Department of Energy

Office of Industrial Programs

Forrestal Building

Washington, DC 20585

\section{K. A. Blakely}

President

Advanced Refractory

Technologies, Inc.

699 Hertel Ave.

BuffaTo, NY 14207

P. Foster

Alcoa Laboratories

P.0. Box 772

New Kensington, PA 15068

W. W. Pritsky

ATuminum Association

900 19th St. N.W.

Washington, DC 20006
No. of

Copies

F. W. Baker

Ceramics Division

Aluminum Company of America

Alcoa Technical Center

Alcoa Center, PA 15069

D. H. DeYoung

Aluminum Company of America

Alcoa Technical Center

Alcoa Center, PA 15069

S. C. Jacobs

Primary Processing

A1uminum Company of America

Alcoa Technical Center

Alcoa Center, PA 15069

N. Jarrett

Aluminum Company of America

Alcoa Technical Center

Alcoa Center, PA 15069

S. P. Ray

Aluminum Company of America

Alcoa Technical Center

Alcoa Center, PA 15069

G. P. Tarcy

Aluminum Company of America

Alcoa Technical Center

Alcoa Center, PA 15069

J. D. Weyand

Aluminum Company of America

Alcoa Technical Center

Alcoa Center, PA 15069

J. Joesowicz

Material Development Laboratory

Atlantic Richfield

20717 Prairie Street

Chatsworth, CA 91311 
No. of

Copies

S. Di amond

Battelle Columbus Laboratories

$505 \mathrm{King}$ Avenue

Columbus, $\mathrm{OH}$ 43201-2693

A. N. Patel

Battelle Columbus Laboratories

505 King Avenue

Columbus, OH 43201-2693

W. Winnard

Battelle Washington Office

2030 "M" Street N.W.

Washington, DC 20036

A. Budner

Bonneville Power Administration

P.0. Box 3621--EPC

Portland, OR 97208

G. Y. Lai

Cabot Corporation

P.0. Box 9013

Kokomo, IN 46902-9013

J. W. Evans

University of California

Dept. of Mat1. Sci. and Mineral Eng.

Berkeley, CA 94720

D. G. Howitt

College of Engineering

University of California, Davis

Davis, CA 95616

L. L. Knapp

Commonwealth Aluminum

85 John Day Dam Road

Goldendale, WA 98620

R. Engdah 1

Deposits and Composites, Inc.

318 Victory Drive

Herndon, VA 22070
No. of

Copies

J. J. Leddy
Dow Chemical U.S.A.
1776 Building
Midland, MI 48640
F. W. Spillers
Dow Chemical U.S.A.
B-1210 Building
Freeport, TX 77541
C. B. Wilson
Dow Chemical U.S.A.
Texas Operations
B-101 Building
Freeport, Tx 77541

M. H. Blenk

Du Pont

P.0. Box 787

Niagara Falls, NY 14302

V. H. Markant

Du Pont

P.0. Box 787

Niagara Falls, NY 14302

M. Baltzell

Eastalco Aluminum Company

Alumax, Inc.

5601 Manor Woods

Frederick, MD 21701

J. V. Anderson

WCVES

EG\&G Idaho, Inc.

Idaho Falls, ID 83415

I. L. Harry

Electric Power Research Institute

P.0. Box 10412

Palo Alto, CA 94303

T. R. Beck

Electrochemical Technology

Corp.

1601 Dexter Avenue

Seattle, WA 98109 
No. of

Copies

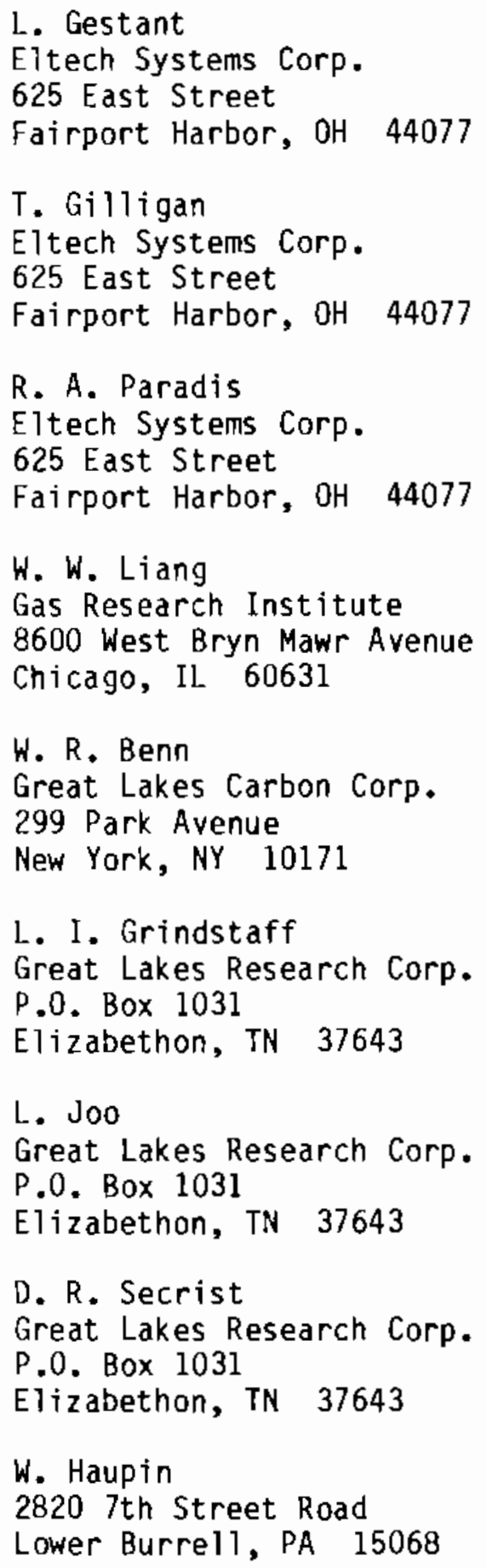

1. Gestant

Eltech Systems Corp.

625 East Street

Fairport Harbor, $\mathrm{OH} 44077$

T. Gilligan

Eltech Systems Corp.

625 East Street

Fairport Harbor, $\mathrm{OH} 44077$

R. A. Paradis

Eltech Systems Corp.

625 East Street

Fairport Harbor, $\mathrm{OH} 44077$

W. W. Liang

Gas Research Institute

8600 West Bryn Mawr Avenue

Chicago, Il 60631

W. R. Benn

Great Lakes Carbon Corp.

299 Park Avenue

New York, NY 10171

L. I. Grindstaff

Great Lakes Research Corp. P.0. Box 1031

Elizabethon, IN 37643

L. Joo

Great Lakes Research Corp.

P.0. Box 1031

Elizabethon, TN 37643

D. R. Secrist

Great Lakes Research Corp. P.0. Box 1031

Elizabethon, TN 37643

W. Haupin

2820 7th Street Road

Lower Burrel1, PA 15068

No. of

Copies

\author{
W. L. Barham \\ Kaiser Aluminum and Chemical \\ Corp. \\ P.0. Box 877 \\ Pleasanton, CA 94566 \\ C. A. Brown \\ Kaiser Aluminum and Chemical \\ Corp. \\ E. 2111 Hawthorne Rd. \\ Mead, WA 99201 \\ J. V. Day \\ Mail Drop 2232 \\ Kaiser Aluminum and Chemical \\ Corp. \\ 300 Lakeside Drive \\ Oakland, CA 94643
}

R. D. Dorward

Kajser Aluminum and Chemical Corp.

P.0. Box 877

Pleasanton, CA 94566

R. A. James

Kaiser ATuminum and Chemical Corp.

P.0. Box 6217

Spokane, WA 99207

J. R. Payne

Kaiser Aluminum and Chemical Corp.

P.0. Box 877

Pleasanton, CA 94566

T. R. Prichett

Kaiser Aluminum and Chemical Corp.

P.0. Box 877

Pleasanton, CA 94566

V. Vera

Kaiser Aluminum and Chemical Corp.

E. 2111 Hawthorne Rd.

Mead, WA 99201 
No. of

Copies

W. G. Lindman

KBI Division of Cabot Corp.

P.0. Box 1462

Reading, PA 19603

R. Keller

RD 3

Roundtop Road

Export, PA 15632

W. N. Maclay

Koppers Company, Inc.

440 College Park Drive

Monroeville, PA 15146

B. G. Epstein

A. D. Little, Inc.

600 Maryland Ave., S.W.

Washington, DC 20024

A. Moussa

A. D. Little, Inc.

20 Acorn Park

Cambridge, MA 02140

L. G. Boxall

Martin Marietta Laboratories

1450 South Rolling

Baltimore, MD 21227

\section{A. Cooke}

Martin Marietta Laboratories

1450 South Rolling

Baltimore, MD 21227

J.A.S. Green

Martin Marietta Laboratories

1450 South Rolling

Baltimore, MD 21227

R. Dethlefsen

Maxwell Laboratories

8888 Balboa Ave.

San Diego, CA 92123
No. of

Copies

J. Goodwell

Center for Metals Production

Mellon Institute

4400 Fifth Avenue

Pittsburgh, PA 15213

R. Unger

Merner Research

P.0. Box 248

Ridgewood, NJ 07451

J. F. Elliott

MIT

Room 4-138

77 Massachusetts Avenue

Cambridge, MA 02139

J. Haggerty

MIT

Building 12, Room 009

77 Massachusetts Avenue

Cambridge, MA 02139

D. R. Sadoway

MIT

Room 8-109

77 Massachusetts Avenue

Cambridge, MA D2139

M. Adkins

National Southwire Aluminum Company

P.0. Box 500

Hawesville, KY 42348

A. B. Shah

Noranda Aluminum, Inc.

P.0. Box 70

New Madras, M0 63869

N. E. Richards

Reduction Laboratory

Reynolds Aluminum Corporation

P.0. Box 1200

Sheffield, AL 35660 
No. of

Copies

R. D. Peterson

Reynolds Metals Company

P.0. Box 1200

Sheffield, AL 35660

D. Strahan

Reynolds Metals Company

P.0. Box 27003

Richmond, VA 23261

C. J. McMinn

Extractive Metallurgical Department

Reynolds Metals Company

P.0. Box 1200

Sheffield, AL 35660

C. W. Doerr

The Stackpole Corporation

Cermag 0ivision

201 Stackpole Street

St. Marys, PA 15857

S. H. Jan

Tennessee Valley Authority 1850 Commerce Union Bank B1dg. Chattanooga, TN 37401

J. A. Barclay

U.S. Bureau of Mines

2401 "E" Street N.W.

Washington, DC 20241

G. R. Hyde

U.S. Bureau of Mines

2401 "E" Street N.W.

Washington, DC 20241

K. Krupinski

Mail Stop 57

U.S. Steel Technical Center

1 Technical Center Drive

Monroeville, PA 15146

J. J. Brown, Jr.

Materials Engineering

Virginia Polytechnic Institute

Blacksburg, VA 24061
No. of

Copies

FORE IGN

D. Brodie

Comalco Ltd.

55 Collins St.

Melbourne, AUSTRALIA

T. Kjar

Comalco Ltd.

55 Collins St.

Melbourne, AUSTRALIA

E. W. Dewing

Alcan Internationa 1

P.0. Box 8400

Kingston, Ontario

CANADA K7L $4 Z 4$

T. J. Hudson

Alcan International

2001 rue University

C.P. 6090

Montrea 1, Quebec

CANADA H3C $3 \mathrm{H} 2$

D. N. MacMillan

Alcan International

C.P. 1250

Jonquieve, Quebec

CANAOA G7S $4 \mathrm{~KB}$

T. Rawlings

Alcan International Limited

Engineering Division

C.P. 6090

Montrea 1, Quebec

CANADA, $\mathrm{H} 3 \mathrm{C} 3 \mathrm{H} 2$

J. H. Reimers

Jan H. Reimers and Associates Inc.

221 Lakeshore Road East

Oakville, Ontario

CANADA L6J $1 \mathrm{H} 7$ 
No. of

Copies

K. Matrasovsky

Institute for Inorganic Chemistry

Centre for Chemical Research

Slovak Academy of Sciences

84236 Bratislava, CZECHOSLOVAKIA

A. Oye

Institute of Inorganic

Chemistry

Norwegian Institute of

Technology

University of Trondheim

N-7D34 Trondheim-NTH, NORWAY

J. Thonstad

Laboratories of Industrial

Electrochemistry

Norwegian Institute of

Technology

University of Trondheim

N-7034 Trondheim-NTH, NORWAY

K. 0. Vee

ASV

Ardal Verk

$\mathrm{N}-5875$ Ardalstargen, NORWAY

\section{ONSITE}

DOE Richland Operations office
No. of

Copies

46 Pacific Northwest Laboratory

K. E. Bailey

D. J. Bradley

J. L. Brimhall

M. Clement

M. J. Danielson

N. C. Davis

J. R. Divine

T. L. Gilbride

P. E. Hart (20)

0. H. Koskj

S. C. Marschman

G. L. McVay

N. L. Moore

J. P. Pilger

K. H. Pool

P. H. Raney

C. H. Schilling

P. H. Swift

C. F. Windisch

B. J. Wrona

Publishing Coordination (2)

Technical Information (5)

D. R. Segna 
